\title{
Mikrobetalinger og forbrugerbeskyttelse
}

Udreder: Lektor Anne-Dorte Bruun Nielsen, Aarhus Universitet

TemaNord 2004:549 


\section{Mikrobetalinger og forbrugerbeskyttelse}

TemaNord 2004:549

(C) Nordisk Ministerråd, København 2004

ISBN 92-893-1046-4

ISSN 0908-6692
Nordisk Ministerråd

Store Strandstræde 18

DK-1255 København K

Telefon $(+45) 33960200$

Telefax (+45) 33960202

\section{Nordisk Råd}

Store Strandstræde 18

DK-1255 København K

Telefon (+45) 33960400

Telefax $(+45) 33111870$

www.norden.org

Det nordiske konsumentsamarbejde

Samarbejdet i Nordisk Embedsmandskomité for Konsumentspørgsmål (NEK) har som mål at fremme forbrugernes sikkerhed, beskyttelse af økonomiske og retlige interesser, uddannelse og information og forbrugerindflydelse i samfundet. Informationsudveksling, udredninger og undersøgelser bidrager til en nordisk forbrugerpolitisk holdning og danner grundlag for fælles optræden i internationale sammenhænge.

\section{Nordisk Ministerråd}

blev oprettet i 1971 som samarbejdsorgan mellem de nordiske landes regeringer. Ministerrådet fremlægger forslag til Nordisk Råds sessioner, viderefører rådets rekommandationer, rapporterer til Nordisk Råd om samarbejdets resultater og leder arbejdet inden for de forskellige emneområder. Samarbejdet koordineres af samarbejdsministrene, der er udpeget af det enkelte lands regering. Ministerrådet træder sammen i forskellige sammensætninger - afhængigt af hvilke spørgsmål, der skal behandles.

\section{Nordisk Råd}

blev oprettet i 1952 som et samarbejdsorgan mellem de folkevalgte forsamlinger og regeringer i Danmark, Island, Norge og Sverige. Finland indtrådte i 1955. Færøernes, Grønlands og Ålands delegationer indgår i henholdsvis Danmarks Riges og Finlands delegationer. Rådet består af 87 medlemmer. Nordisk Råd er initiativtagende og rådgivende og har kontrollerende opgaver i det nordiske samarbejde. Nordisk Råds organer er plenarforsamlingen, præsidiet og udvalgene. 


\section{Indhold}

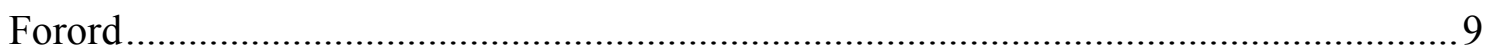

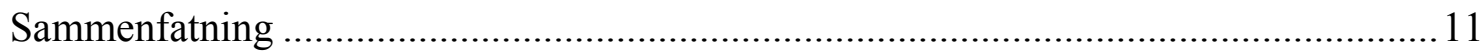

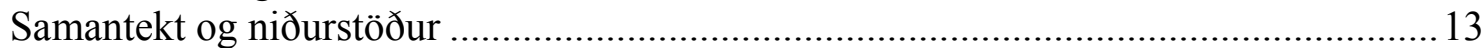

Yhteenveto ja johtopäätökset …………………………………………………....15

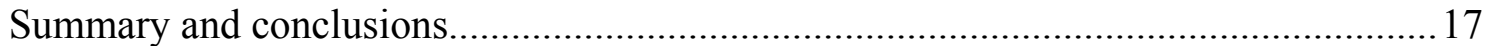

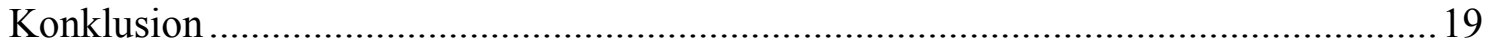

1 Rapportens baggrund, begreber og juridiske rammer ...........................................23

1.1 Indledende bemærkninger. Behovet for en redegørelse.................................23

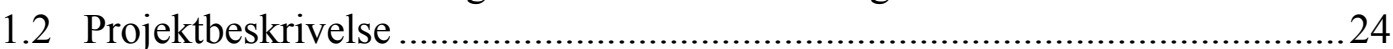

1.3 Fastlæggelse af nogle begreber..................................................................25

1.3.1 Realydelse og pengeydelse. Vare og/eller tjenesteydelse....................25

1.3.2 Betaling over telefonen ....................................................................26

1.3.3 Definition af mikrobetaling ……………………………………......2

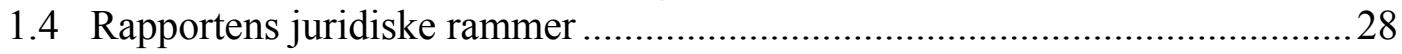

2 Beskrivelse af mikrobetalings-systemer ………………......................................

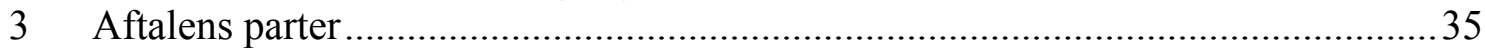

4 Indgåelsen af mikroaftaler og aktørernes ansvar for egne og

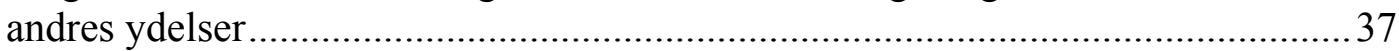

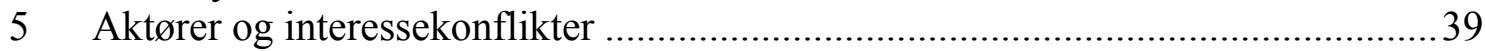

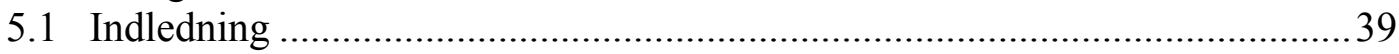

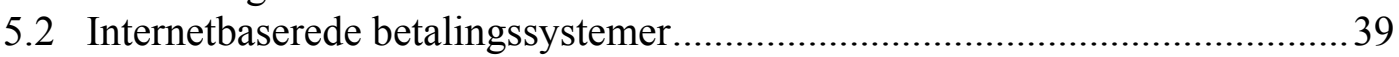

5.3 Overtakserede SMS/MMS-systemer via teleselskaberne ..................................40

5.4 Andre betalingssystemer ..............................................................................4

5.5 Interessekonflikter mellem udbyderne af mikrobetalings-systemer. ............... 40

6 Identifikation af de retlige problemer vedrørende mikroaftaler og -betalinger..................................................................................4

6.1 Generelt: Hvad gør, at der er særlige problemer ved mikro-aftaler ................41

6.2 Behov for oplysninger................................................................................ 43

6.2.1 Forudbetalte systemer uden konto - "ihændehaverkort" (småpengekort, elektroniske billetter m.v.).........................................43

6.2.2 Mikrobetalinger med løbende konto ....................................................4 44

6.3 Sikkerhed mod tredjemands misbrug.......................................................... 44

6.3.1 Misbrug begået af udefrakommende tredjemand.................................. 44

6.3.2 Sikkerhed mod misbrug fra betalingsformidleren eller betalingsmod-

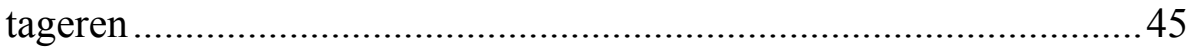

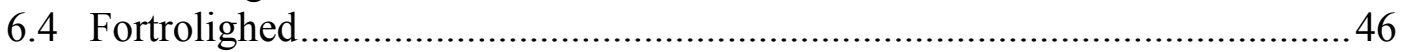

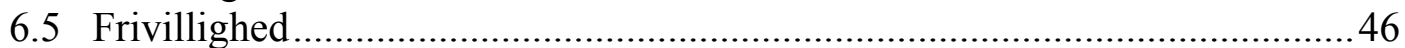

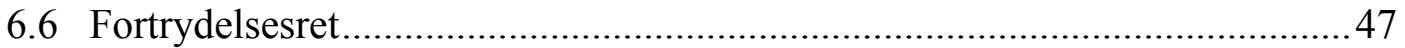

6.7 Sikring mod eget "uagtsomme" overforbrug ...................................................4 47

6.8 Særlige problemstillinger i relation til børn og unge ...................................... 48 
6.8.1 Mulighed for at spærre for køb af overtakserede SMS/MMS ........... 48

6.8.2 Hvem hæfter for den mindreåriges forbrug?.................................... 48

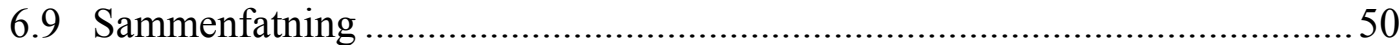

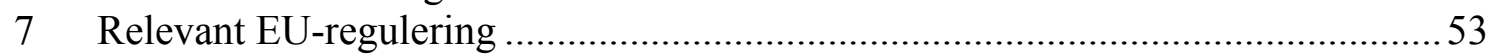

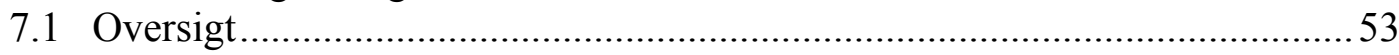

7.2 Direktiv om vildledende og sammenlignende reklame (84/450 som ændret

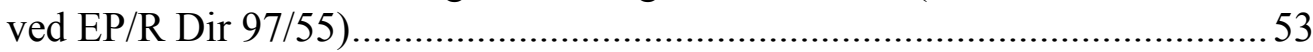

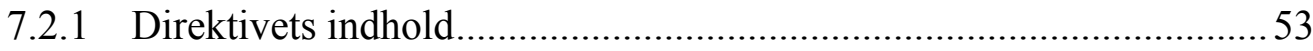

7.2.2 Direktivet set i forhold til mikrobetalinger ........................................5 54

7.3. Direktiv om forbrugerbeskyttelse i forbindelse med aftaler indgået uden for fast forretningssted (R dir 85/577/EØF) ........................................................ 54

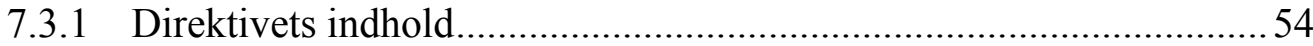

7.3.2 Direktivet set i forhold til mikrobetalinger ....................................... 54

7.4 Direktiv om forbrugerbeskyttelse i forbindelse med aftaler vedrørende

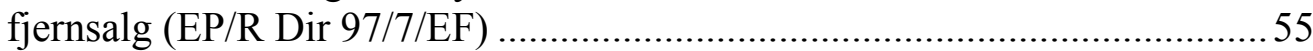

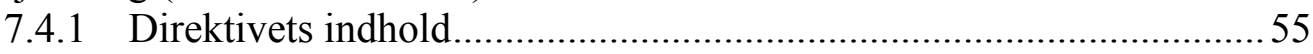

7.4.2 Direktivet set i forhold til mikrobetalinger ...................................... 58

7.5 Direktiv om visse retlige aspekter af informationssamfundstjenester, navnlig elektronisk handel, i det indre marked (Direktivet om elektronisk

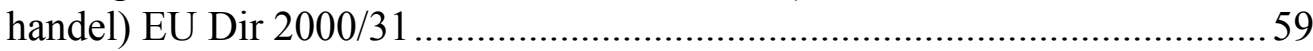

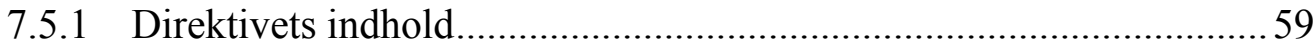

7.5.2 Direktivet set $\mathrm{i}$ forhold til mikrobetalinger ..........................................6 60

7.6 Direktiv om fjernsalg af finansielle ydelser til forbrugerne

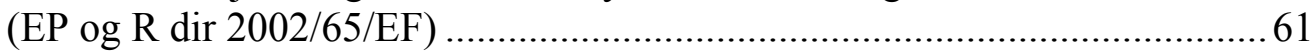

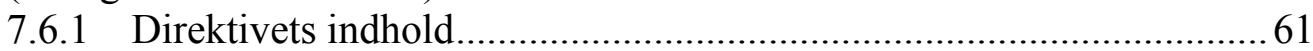

7.6.2 Direktivet set $\mathrm{i}$ forhold til mikrobetalinger ........................................6 62

7.7 Direktiv om urimelige kontraktvilkår i forbrugeraftaler ( $\mathrm{R}$ dir 93/13).........63

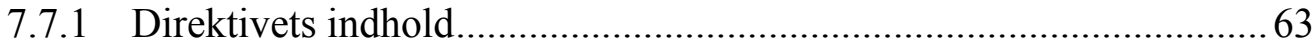

7.7.2 Direktivet set i forhold til mikrobetalinger .........................................63

7.8 Direktiv om forbrugerkredit (R Dir 87/102 som senest ændret ved

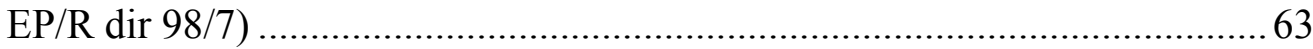

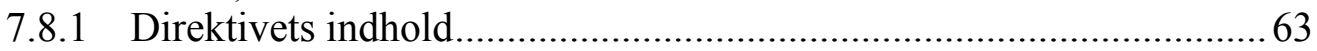

7.8.2 Direktivet set i forhold til mikrobetalinger ........................................64 64

7.9 Kommissionens henstilling om transaktioner med elektroniske betalingsmidler, især forholdet mellem udsteder og indehaver

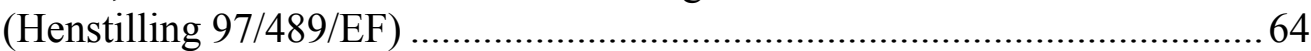

7.10 Meddelelse fra Kommissionen til Rådet og Europaparlamentet om en ny retslig ramme for betalinger i det indre marked............................................65

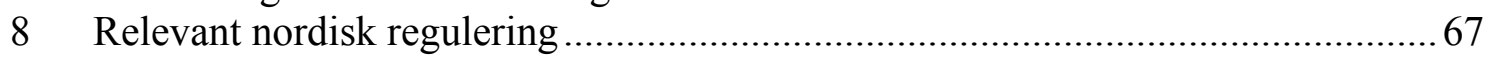

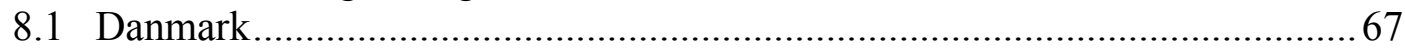

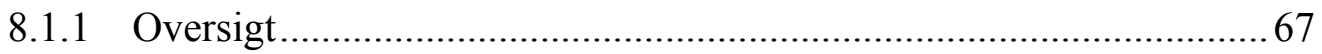

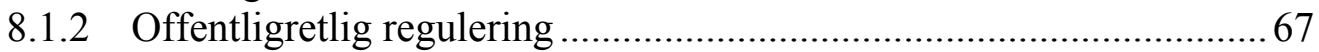

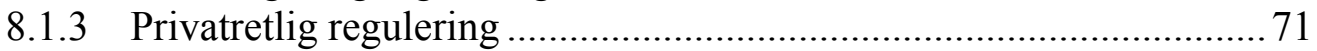

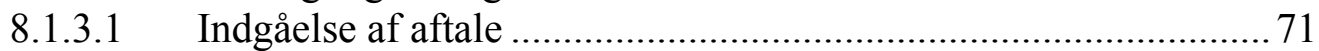

8.1.3.2 Oplysningspligten inden aftalen indgås ....................................... 72

8.1.3.3 Oplysninger m.v. efter aftaleindgåelsen ....................................... 74

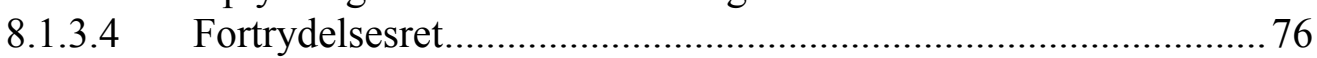

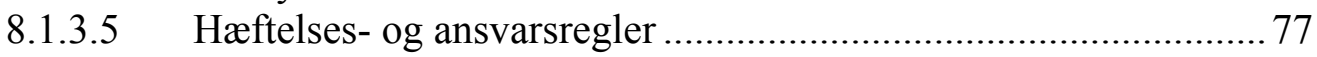

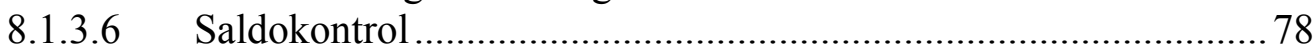


8.1.4 Opfylder dansk lovregulering forbrugerens behov for beskyttelse..... 79

8.1.5 Giver dansk lovregulering anledning til barrierer i udviklingen af

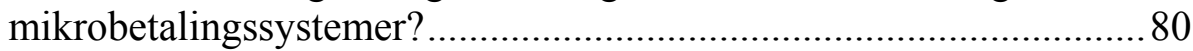

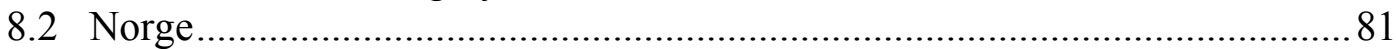

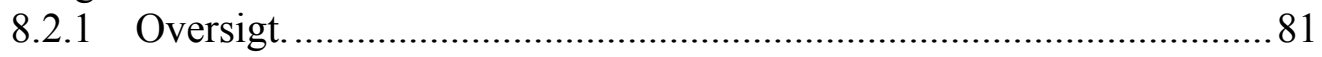

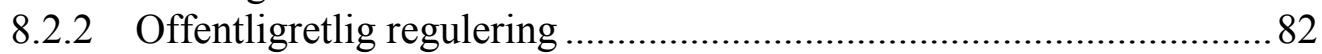

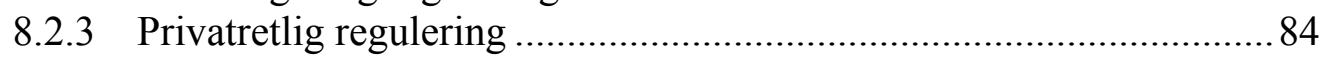

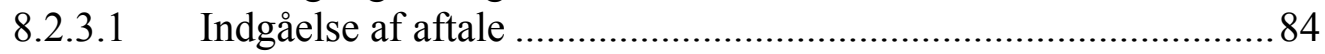

8.2.3.2 Oplysningspligten inden aftalen indgås ....................................... 85

8.2.3.3 Oplysninger m.v. efter aftaleindgåelse ...................................... 86

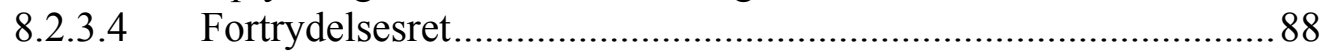

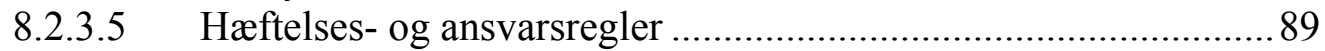

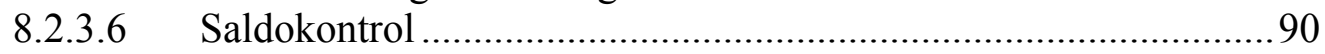

8.2.4 Opfylder norsk lovregulering forbrugernes behov for beskyttelse? ...90

8.2.5 Giver norsk lovregulering anledning til barrierer i udviklingen af mikrobetalingssystemer?........................................................... 91

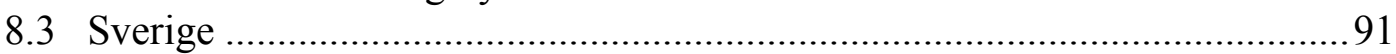

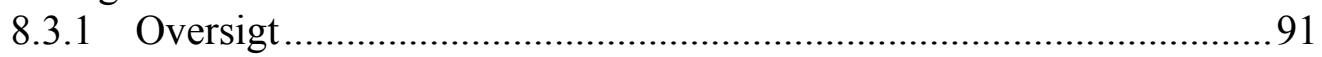

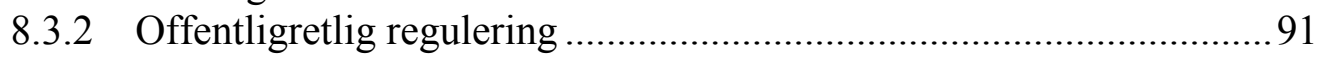

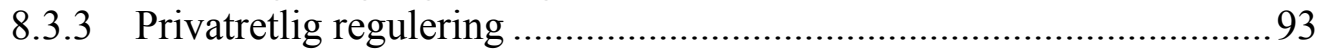

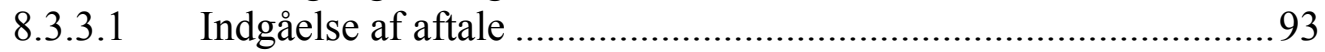

8.3.3.2 Oplysningspligten inden aftalen indgås ...................................... 94

8.3.3.3 Oplysninger m.v. efter aftaleindgåelsen ......................................96

8.3.3.4 Fortrydelsesret........................................................................... 98

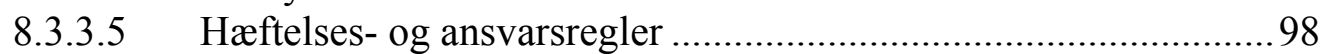

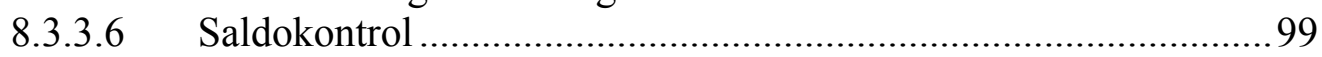

8.3.4 Opfylder svensk lovregulering forbrugernes behov for beskyttelse? 99

8.3.5 Giver svensk lovregulering anledning til barrierer i udviklingen af

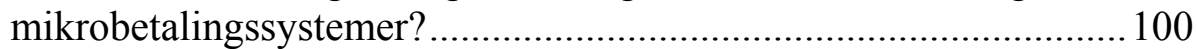

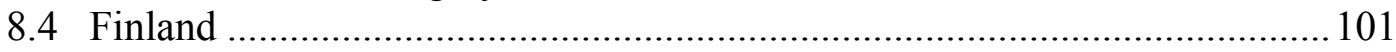

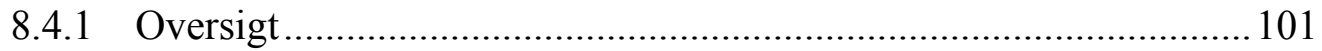

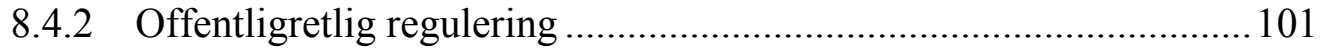

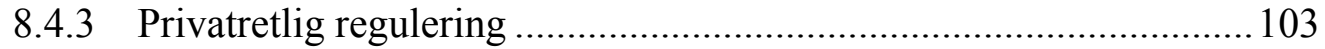

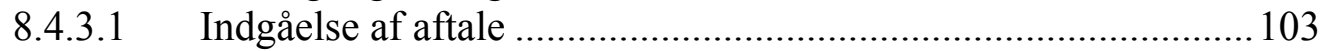

8.4.3.2 Oplysningspligten inden aftale indgås ........................................ 104

8.4.3.3 Oplysninger m.v. efter aftalens indgåelse .................................. 106

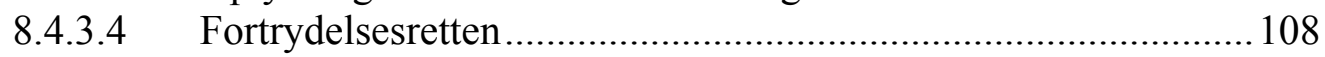

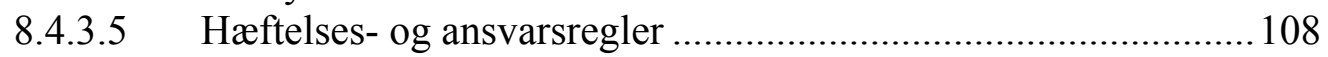

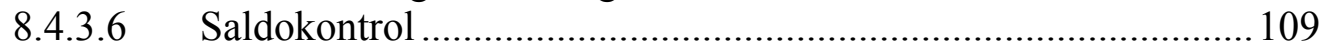

8.4.4 Opfylder finsk lovgivning forbrugernes behov for beskyttelse?...... 109

8.4.5 Giver finsk lovgivning anledning til barrierer i udviklingen af

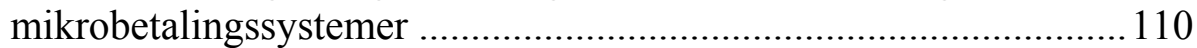

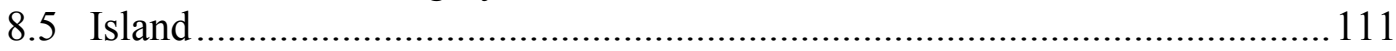

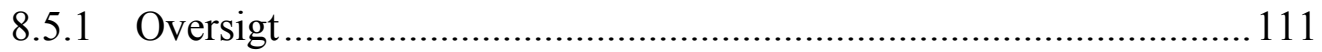

8.5.2 Offentligretlig regulering ............................................................ 111

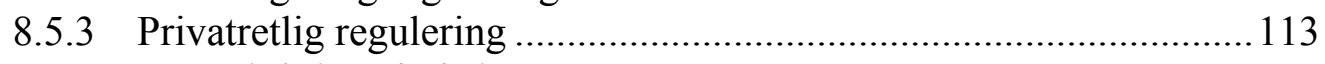

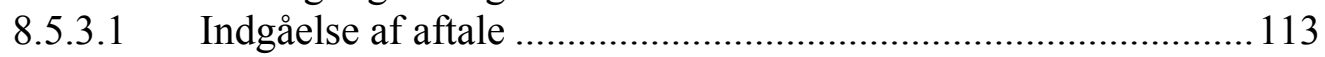

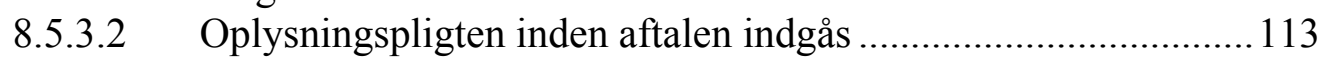

8.5.3.3 Oplysningspligten efter aftaleindgåelsen ................................. 115 


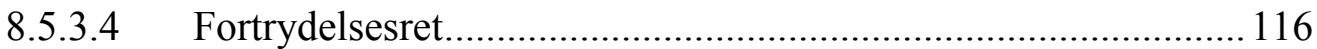

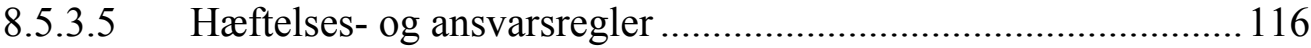

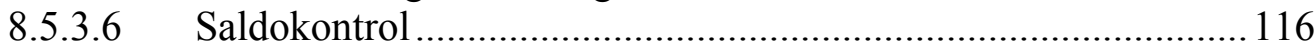

8.5.4 Opfylder islandsk lovregulering forbrugerens behov for

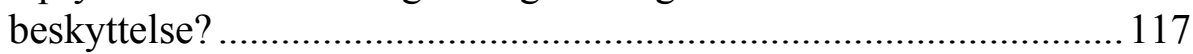

8.5.5. Giver islandsk lovregulering anledning til barrierer i udviklingen

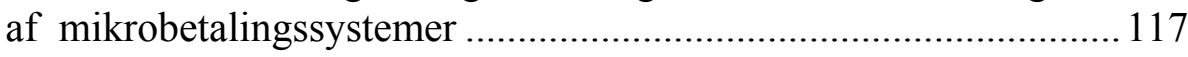




\section{Forord}

Denne rapport omhandler de retslige problemer ved betaling af små beløb via overtakserede SMS/MMS beskeder, (forudbetalte) betalingssystemer med tilknytning til en eller flere erhvervsdrivende og andre betalingssystemer udviklet med henblik på småbetalinger - mikrobetalinger, samt om de retslige barrierer, der kan antages at være ved udviklingen af sådanne systemer.

Rapporten er blevet til som et resultat af et udredningsarbejde foretaget for Nordisk Ministerråd, under et projekt påbegyndt i foråret 2003 og afsluttet i foråret 2004.

Anders Hjorth Jensen, Forbrugerrådet, Danmark, har været projektleder, og den nedsatte styregruppe bestod af Vesa Vuoti, Konsumentverket, Finland, Geir Arnar Marelsson, Neytendasamtökin, Island (afløst af Iris Ösp Ingjaldsdóttir, samme sted) Stian Schilvold, Forbrukerombudet, Norge og Pär Nordfors, Konsumentverket, Sverige.

Lektor, cand. Jur. Anne-Dorte Bruun Nielsen, Aarhus Universitet har været udreder på rapporten.

Rapporten er opbygget således, at den indledes med en beskrivelse af mikroaftaler og de parter, der deltager heri. Dette følges af en analyse af, hvilke særlige problemer, der må antages at gælde for mikroaftaler og mikrobetalinger. Derefter kommer en gennemgang af den relevante EU-retlige regulering efterfulgt af en gennemgang af national ret $\mathrm{i}$ Danmark, Norge, Sverige, Finland og Island. Dertil findes sammenfatning og konklusioner. Rapporten afstår fra fristelsen til at udforme konkrete lovregler for de enkelte lande!

Denne opbygning af rapporten har betydet, at der bliver en vis gentagelse af en del af de relevante problemstillinger, hvilket bl.a. skyldes, at en stor del af de behandlede lovkomplekser dels er "fællesnordisk gods", dels er direktivbaserede, og derfor stort set er identiske fra land til land. Af denne grund er visse problemstillinger mest uddybende behandlet under beskrivelsen af Danmark, da det er dette land, der er først beskrevet. På den anden side er retsstillingen forsøgt beskrevet nogenlunde sammenhængende og dækkende for de enkelte lande, således at disse i et rimeligt omfang kan læses enkeltvis. Rapporten skal dog læses som et samlet forløb for at få det fulde udbytte af den. 


\section{Sammenfatning}

Denne rapport søger at afdække en bred vifte af de problemstillinger, der vedrører aftaler om tilslutning til mikrobetalingsmidler og vedrørende den enkelte mikroaftale.

Det har vist sig, at de nordiske lande (med Island som en vis grad af undtagelse) også på mikroaftaleområdet stadig har en høj grad af retsenhed og retsfcellesskab. Mange af de behandlede lovområder og enkeltregler er næsten identiske - $\mathrm{i}$ hvert fald i deres materielle indhold - fra land til land, hvilket også skyldes, at mange af de relevante regler nu er direktivbaserede, og derfor må forventes at have en høj grad af ensartethed. Dette vil fremgå af beskrivelsen af de enkelte lande.

Svaret på, om der kan lempes på nogle af de forbrugerbeskyttende regler af hensyn til de erhvervsdrivendes mulighed for at udvikle mikrobetalingssystemer, afhænger af, hvordan man forventer, at mikrobetalingsområdet udvikler sig i fremtiden. Området er inde $\mathrm{i}$ en rivende udvikling, og f.eks. betaling via overtakserede SMS/MMS'er kunne se ud til at være i en udvikling, der kunne gøre det til et nyt, generelt betalingsmiddel. Dette aspekt skærper opmærksomheden på forbrugerbeskyttelsen og maner til nogen forsigtighed. Hvis man ønsker at lempe reglerne på enkelte områder, vil det være formålstjenligt, om dette sker i et tæt samarbejde de nordiske lande imellem, således at retsenheden og retsfællesskabet bevares. Dette vil også styrke samhandelen imellem de nordiske lande og forenkle forholdene både for forbrugerne og de erhvervsdrivende.

Der har tegnet sig en række områder, hvor forbrugerbeskyttelsen enten i enkelte eller alle de nordiske lande kunne trænge til en styrkelse, idet ingen af de undersøgte lande har en lovgivning, der på alle punkter fungerer optimalt med henblik på beskyttelse af forbrugeren. Sammenfattende kan bemærkes:

1) Et af de væsentligste problemer er den manglende klare regulering af, hvad der galder for forbrugerens haftelse for tredjemands uberettigede misbrug af det betalingsmiddel, som en mobiltelefon med mulighed for at anvende overtakserede $S M S / M M S$ 'er må anses at vare. Der mangler bl.a. en beløbsgrænse for forbrugerens selvrisiko, således som dette findes vedrørende misbrug af kontokort i Danmark (1.200 kr.) og Norge (800 kr.) ikke mindst set i lyset af, at mobiltelefonen som betalingsmiddel må anses for at være et ikke-sikkert betalingsmiddel.

2) Det er en betydelig svækkelse af forbrugerens mulighed for at overskue sin juridiske og praktiske situation, at teleselskabernes kontrakter i urimelig høj grad er uoverskuelige, vanskeligt tilgængelige og uklare. Der bør arbejdes på at få teleselskaberne til at udfærdige enkle, klare og brugervenlige kontrakter.

3) Der er et væsentligt behov fra forbrugerside (og der må formodes også at være et sådant fra visse erhvervsdrivendes side), for at kunne aftale saldokontrol for mobiltelefonabonnementer, ligesom der er et stort behov for at kunne spærre for muligheden af, at der kan anvendes (visse typer af) overtakserede SMS/MMS'er uden at spærre for anvendelsen af almindelige tekstbeskeder. Manglen på disse muligheder medfører, at forbrugere er henvist til enten at løbe risikoen ved den manglende saldokontrol/spærring, eller må tage til takke med de meget dyre taletidskort (hvorpå der i øvrigt ikke er spærret for køb af overtakserede SMS/MMS'er). 
4) Der mangler mulighed for, at mobiltelefonens funktion som betalingsmiddel kan spærres med en særlig kode/kun kan åbnes med en særlig kode. Dette ville betyde, at mobiltelefonen som betalingsmiddel i højere grad kunne anses som et sikkert betalingsmiddel, hvilket kunne beskytte forbrugeren mod uberettiget tredjemands brug, ligesom det ville øge forbrugerens mulighed for kontrol af børns brug af telefonen.

5) Der har ved gennemgangen af de regler, der implementerer fjernsalgsdirektivets artikel 5, stk. 2 om fritagelse for at afgive ordrebekræftelse på varigt medium vist sig at være forskelle i den måde, hvorpå de nordiske lande har gjort dette. Danmark og Island har indtil videre implementeret undtagelsen i artikel 5, stk. 2 i overensstemmelse med det, der var formålet med denne, jævnfør direktivets bemærkninger om, at forbrugerne ikke bør få færre oplysninger ved handel med elektroniske kommunikationsmidler og i overensstemmelse med, hvorledes den er eksemplificeret $\mathrm{i}$ forarbejderne til direktivet (hvor der nævnes opkald til oplysningstjeneste). Norge, Sverige og Finland har implementeret reglen således, at det, der var tænkt som en snæver undtagelse kan blive hovedreglen, medens det, der var bestemmelsens hovedregel, nemlig at der skal gives forbrugeren en ordrebekræftelse med alle til aftalen relevante oplysninger på papir eller andet varigt medium, må blive undtagelsen. Dette må anses for problematisk, såfremt disse lande ikke lægger en meget snæver fortolkning af undtagelsesbestemmelsen til grund.

6) Det bør overvejes at indføre et selvstændigt ansvar for teleudbyderne for tjenesteudbydernes grove og/eller gentagne krænkelser af forbrugerne eller af reglerne om god markedsføringsskik. Dette kunne være hensigtsmæssigt f.eks. i tilfælde af udbyders grove krænkelser af børn eller ved groft misbrug af betalingsopkrævninger. Der findes i Sverige og Danmark etiske regler og aftaler, der forpligter en teleudbyder til at afbryde samarbejdet med en tjenesteudbyder, der overtræder de etiske regler groft og/eller gentagne gange. Sådanne regler kunne med gavn for forbrugerbeskyttelsen indføres generelt i de nordiske lande. 


\section{Samantekt og niðurstöður}

Í pessari skýrslu hefur verið leitast við að útskýra fjölmörg álitamál varðandi samninga um tengingu við aðferðir í örgreiðslu (micropayment) og varðandi hvern einstakan örgreiðslusamning.

Pað hefur komið í ljós að á Norðurlöndum (nema að vissu leyti á Íslandi) er ennpá mjög svipað réttarfar, einnig hvað varðar örgreiðslusamninga. Mörg lagasvið og einstaka reglur eru nær samhljóða alls staðar - að minnsta kosti efnislega séð, en pað orsakast af pví hversu mikið af viðkomandi reglum byggir orðið á ESB-tilskipunum. Par af leiðandi verða pær mjög svipaðar. betta sést í umfjöllun um hin einstöku lönd.

Svarið við pví hvort hægt sé að draga úr neytendaverndarreglum með tilliti til möguleika atvinnurekenda á að próa örgreiðslukerfi fer eftir bví hvernig búast megi við að örgreiðsluaðferðin próist í framtíðinni. Mál pessi eru í hraðri próun en sú greiðsluaðferð að nota SMS og MMS skeyti á yfirverði virðist til að mynda vera að próast út í pað að verða nýr almennur greiðslumáti. bessi notkun kallar á aukna athygli um neytendavernd og hvetur til nokkurrar varkárni. Ef óskað er eftir að draga úr reglum á ákveðnum sviðum mun vænlegast að Norðurlöndin geri pað í náinni samvinnu pannig að réttarfarið haldist svipað. Ьað mun einnig auka viðskipti milli Norðurlandapjóðanna og einfalda kjör neytenda og atvinnurekenda.

Pað lítur út fyrir að neytendavernd á mörgum sviðum hjá sumum ef ekki öllum Norðurlandapjóðanna parfnist styrkingar par sem ekkert peirra landa sem hafa verið til skoðunar eiga sér löggjöf sem pjónar hagsmunum neytendans í hvívetna. Heildarniðurstaðan er eftirfarandi:

1) Eitt meginvandamál er skortur á skýrum reglum um greiðsluábyrgð neytendans ef priðji aðili misnotar í heimildaleysi greiðsluaðferðina sem er farsími með möguleika á að senda SMS og MMS skeyti á yfirverði. M.a. vantar reglur um hámark sjálfsábyrgðar neytandans, líkt og pær reglur sem gilda varðandi misnotkun á greiðslukortum í Danmörku (1.200 kr.) og í Noregi (800 kr.), ekki síst í ljósi pess að farsími sem er notaður sem greiðslumiðill hlýtur að vera álitinn áhættusamur greiðslumiðill.

2) Баð dregur verulega úr möguleikum neytandans á að meta lagalega stöðu sína og almenna, að samningar við símafyrirtækin eru í hæsta máta illskiljanlegir, óaðgengilegir og óljósir. Pví ber að vinna að pví að fá símafyrirtækin til að semja einfalda, skiljanlega og neytendavæna samninga.

3) Hjá neytendum (og væntanlega einnig hjá sumum atvinnurekendum) er áberandi pörf fyrir að geta samið um hámark úttektar vegna farsímaáskriftar, og eins er brýn pörf fyrir leiðir til að koma í veg fyrir að hægt sé að nota vissar tegundir SMS og MMS skeyta á yfirverði án pess að purfa að loka fyrir venjuleg textaskeyti. Skortur á pessum möguleika hefur í för með sér að neytendur neyðast annaðhvort til að taka áhættuna með ólæstri greiðsluaðferð, eða sætta sig við mjög dýr talfrelsiskort (sem eru auk pess ekki lokuð fyrir SMS og MMS skeytum á yfirverði).

4) Раð parf að vera hægt að virkja og óvirkja farsímann með sérstökum aðgangslykli til pess að nota hann sem greiðslumiðil. Рað myndi hafa í för með sér að frekar yrði 
hægt að skoða farsímann sem öruggan greiðslumiðil. Par með yrði hægt að vernda neytandann gegn misnotkun priðja aðila svo og að tryggja eftirlit með notkun barna á símanum.

5) Pegar farið var yfir reglurnar sem lögleiða 2. mgr., 5. gr. tilskipunar um fjarsölu, um undanpágu frá staðfestingu pöntunar á varanlegum miðli, kom í ljós munur á framkvæmd á Norðurlöndum. Danir og Íslendingar hafa eins og er lögleitt undanpágu 2. mgr., 5. gr. í samræmi við pað sem var markmið hennar, samanber athugasemdir í tilskipuninni um að neytandinn eigi ekki að fá rýrari upplýsingar við viðskipti í gegnum rafræna tjáskiptamiðla, og í samræmi við dæmin sem nefnd voru við undirbúningsvinnuna við tilskipunina (par sem nefndar eru upphringingar í upplýsingapjónustu). Norðmenn, Svíar og Finnar hafa lögleitt regluna pannig að pað sem var hugsað sem pröng undanpága gæti orðið aðalreglan, en pað sem ætti að vera aðalreglan verði undantekningin, p.e. að gefa skuli neytandanum staðfestingu pöntunar með öllum upplýsingum varðandi samninginn, á pappír eða öðrum varanlegum miðli. betta verður að teljast varhugavert nema pessi lönd byggi á mjög pröngri túlkun á undanpáguákvæðinu.

6) Íhuga verður hvort eigi ekki að koma á sérstakri ábyrgð fjarskiptaútbjóðenda vegna grófra og/eða endurtekinna brota peirra gagnvart neytendum eða á reglunum um góða markaðssetningu. Petta gæti verið hentugt t.d. í grófum tilfellum, par sem börn koma við sögu eða við grófa misnotkun innheimtu. Í Svípjóð og Danmörku eru til siðareglur og sampykktir sem skylda fjarskiptaútbjóðanda til að slíta samvinnu við pjónustuútbjóðanda ef hann fer gróflega og/eða endurtekið yfir siðamörk. Slíkar reglur gætu orðið neytendum til gagns ef pær öðluðust almennt gildi á Norðurlöndum. 


\section{Yhteenveto ja johtopäätökset}

Raportissa tarkastellaan mikromaksuvälineiden liittymissopimuksiin ja yksittäisiin mikrosopimuksiin liittyviä erilaisia ongelmia Pohjoismaissa.

Yleisesti ottaen voidaan todeta, että Pohjoismailla (Islantia eräissä tapauksissa lukuun ottamatta) on myös mikromaksamisen alueella pitkälti yhtenevä ja yhdenmukainen lainsäädäntö. Monet tarkastelun kohteena olleista lain alueista ja yksittäisistä säännöksistä ovat ainakin asiasisältönsä puolesta lähes yhteneviä eri Pohjoismaissa. Osittain tämän voidaan katsoa johtuvan siitä, että monet kyseisistä säännöksistä perustuvat tätä nykyä direktiiveihin, jolloin niiltä voidaankin odottaa tiettyä yhdenmukaisuutta. Tämä käy ilmi mm. maakohtaisista kuvauksista.

Alan kehitykseen kohdistuvista odotuksista riippuu, missä määrin on mahdollista parantaa eräitä kuluttajansuojaa koskevia säännöksiä, jotta mikromaksujärjestelmiä voitaisiin kehittää. Ala kehittyy koko ajan ripeästi ja vaikuttaa siltä, että esim. lisämaksullisista tekstiviesteistä on tulossa uusi ja yleinen maksuväline. Tämä pakottaa kiinnittämään huomiota kuluttajansuojaan ja etenemään tiettyä varovaisuutta noudattaen. Jos säännöksiä halutaan kehittää joillakin yksittäisillä osa-alueilla, se on tarkoituksenmukaista tehdä tiiviissä yhteistyössä Pohjoismaiden kesken siten, että lainsäädännön yhtenevyys ja yhdenmukaisuus säilyy. Tämä on omiaan helpottamaan paitsi Pohjoismaiden välistä kaupankäyntiä myös kuluttajien ja elinkeinonharjoittajien toimintamahdollisuuksia.

Tarkastelussa löytyi useita osa-alueita, joilla kuluttajansuojaa voitaisiin parantaa joko yhdessä Pohjoismaassa tai kaikissa Pohjoismaissa. Tämä johtuu siitä, että missään tutkimuksen kohteena olleista maista lainsäädäntö ei toimi joka suhteessa optimaalisesti, jos asiaa tarkastellaan nimenomaan kuluttajansuojan kannalta. Yhteenvetona voidaan todeta seuraavaa:

1) Yksi suurimmista ongelmista on selkeiden säännösten puuttuminen kuluttajan vastuusta siinä tapauksessa, että kolmas osapuoli käyttää oikeudettomasti väärin sellaista maksuvälinettä, esim. matkapuhelinta, johon liittyy mahdollisuus käyttää lisämaksullisia tekstiviestejä. Kuluttajan omavastuulle ei esimerkiksi ole asetettu samanlaista ylärajaa kuin pankkiautomaattikorttien väärinkäytölle Tanskassa (1 200 kruunua) ja Norjassa (800 kruunua). Tämä on selkeä puute, varsinkaan kun matkapuhelinta ei voida pitää erityisen turvallisena maksuvälineenä.

2) Kuluttajan mahdollisuuksia saada kokonaiskuva oikeudellisesta ja käytännön tilanteestaan vaikeuttaa merkittävästi se seikka, että teleyhtiöiden sopimukset ovat usein kohtuuttoman vaikeaselkoisia ja epäselviä sekä vaikeasti kuluttajan saatavissa. Teleyhtiöt on velvoitettava laatimaan yksinkertaisia, selkeitä ja käyttäjäystävällisiä sopimuksia.

3) Kuluttajat, ja myös osa elinkeinonharjoittajista, haluaisi saldokontrollin matkapuhelinliittymäänsä. Monet haluaisivat lisäksi eston tietyntyyppisten ylihinnoiteltujen tekstiviestien käytölle kuitenkin niin, että tavallisten tekstiviestien lähettäminen olisi mahdollista. Saldokontrollin tai eston puuttuminen saattaa aiheuttaa kuluttajalle hankaluuksia maksutilanteissa. Kuluttaja saattaa myös joutua turvautumaan kalliisiin puheaikakortteihin (joissa ei ole estoa ylihinnoiteltujen tekstiviestien ostamiseen). 
4) Mahdollisuus matkapuhelimen maksuvälinetoiminnon estämiseen/ avaamiseen erityisellä koodilla puuttuu tällä hetkellä. Tällainen toiminto olisi omiaan tekemään matkapuhelimesta turvallisemman maksuvälineen, joka suojelisi kuluttajia kolmannen osapuolen oikeudettomalta väärinkäytöltä. Se parantaisi myös kuluttajien mahdollisuuksia valvoa lasten puhelimen käyttöä.

5) Tarkasteltaessa etämyyntidirektiivin 5. artiklan 2. kohdan (vapautus tilausvahvistuksen tekemisestä pysyvällä välineellä) täytäntöönpanosäännöksiä voidaan todeta, että Pohjoismaat ovat toteuttaneet niitä hieman eri tavalla. Tanska ja Islanti ovat toistaiseksi toteuttaneet artiklan 5.2 poikkeusta sen alkuperäistä tarkoitusta vastaavalla tavalla (vrt. direktiivin huomautukset) eli siten, että kuluttajien on saatava samat tiedot sähköisten viestintävälineiden välityksellä tapahtuvan kaupan yhteydessä kuin tavanomaisessa kaupassa, samoin kuin direktiivin esitöissä annettujen esimerkkien mukaisesti (joissa mainitaan tiedonantovelvoite). Norja, Ruotsi ja Suomi ovat puolestaan toteuttaneet säännöstä siten, että kapea-alaiseksi poikkeukseksi tarkoitetusta säännöksestä voi tulla pääsäännös, kun taas määräyksen pääsäännöksestä, jonka mukaan kuluttajalle on annettava tilausvahvistus kaikkine sopimukseen liittyvine asianmukaisine tietoineen paperilla tai muulla pysyvällä välineellä, tulee poikkeus. Tätä on pidettävä ongelmallisena, jos kyseiset maat eivät käytä täytäntöönpanon perustana poikkeussäännöksen erittäin kapeaa tulkintaa.

6) Teleyhtiöiden osalta tulee harkita itsenäistä vastuuta siltä varalta, että palvelun tarjoaja menettelyllään loukkaa törkeästi ja/tai toistuvasti kuluttajien etuja tai rikkoo hyvää markkinointitapaa koskevia säännöksiä. Tämä saattaisi olla tarkoituksenmukaista esimerkiksi silloin, kun palvelun tarjoajan menettely loukkaa törkeästi lasten etuja tai jos maksujen perimiseen liittyy törkeää väärinkäyttöä. Ruotsilla ja Tanskalla on eettisiä sääntöjä ja sopimuksia, jotka velvoittavat teleyhtiöitä lopettamaan yhteistyön tällaisia eettisiä sääntöjä törkeästi ja/tai toistuvasti rikkovan palvelun tarjoajan kanssa. Tällaiset säännöt voitaisiin ottaa yleisesti käyttöön kaikissa Pohjoismaissa kuluttajansuojaa lisäävänä toimenpiteenä. 


\section{Summary and conclusions}

The purpose of this report is to identify a wide range of problems in relation to contracts on the connection to means of micro-payment and in relation to individual micropayment contracts.

It appears that the Nordic countries (Iceland is to some extent an exception) still have a high degree of unification of law and community of law, also in the micro-payment area. Many of the legal areas and individual rules examined are almost identical in all countries - at least as regards the material contents - which may also be due to the fact that many of the relevant rules are now based on directives and must therefore be expected to be highly uniform. This will also appear from the description of each country.

Whether some consumer protection rules may be relaxed in order to secure traders' possibilities of developing micro-payment systems depends on how the micro-payment area is expected to develop in future. The area is seeing a violent process of change, and for instance payment via overcharged SMS/MMS seems to be developing in a way which might turn it into a new, general means of payment. This aspect claims attention to consumer protection and requires careful handling. If there is a wish to relax the rules in certain areas, it will be appropriate to do this in close co-operation between the Nordic countries in order that the unification of law and community of law are maintained. This will also strengthen trade between the Nordic countries and make matters simpler to both consumers and traders.

A number of areas have emerged where consumer protection in some or all countries might need to be strengthened, as none of the countries examined have legislation which functions optimally in all respects when it comes to protecting the consumer. Summing up:

1) One of the most important problems is the lack of clear regulation of what applies to the consumer's liability for a third party's misappropriation of the means of payment which a mobile telephone that can use overcharged SMS/MMS must be considered to be. For instance there is no ceiling on the consumer's own risk like it is found in connection with the misuse of credit cards in Denmark (1.200 Kr.) and Norway (800 $\mathrm{Kr}$.). This should not least be seen in the light of the fact that the mobile telephone as a means of payment must be considered a non-safe means of payment.

It is a considerable weakening of the consumer's possibility of assessing his legal or practical situation that the telecom companies' contracts are unreasonably disorderly, difficult to understand and unclear. The telecom companies should be made to draw up simple, clear and user-friendly contracts.

2) There is a considerable need on the part of consumers (and probably also on the part of traders) to be able to make arrangements for balance control for mobiletelephone subscriptions, and there is also a big need to be able to bar the possibility of using (certain types of) overcharged SMS/MMS without barring the use of ordinary text messages. The lack of these possibilities means that consumers either have to expose themselves to the risks of the lacking balance control/barring or be content with the 
very expensive calling cards (which do actually not bar purchases of overcharged SMS/MMS).

3) There is a lack of the possibility that the mobile telephone function as a means of payment can be barred with a special code / can only be opened with a special code. This would mean that the mobile telephone as a means of payment could be regarded as a more safe means of payment, which could protect the consumer against unauthorised third party use, and it would also increase the consumer's possibility of control of children's use of the telephone.

4) The examination of the rules implementing article 5 (2) of the distance sales directive regarding the exemption from acknowledging orders on a durable medium showed that the Nordic countries had done this in different ways. Denmark and Iceland have so far implemented the exemption in article 5 (2) in accordance with the purpose of this article, cf. the remarks in the directive that consumers should not receive less information when buying via electronic means of communication, and in accordance with the exemplification in the preliminary work of the directive (where calls for information services are mentioned). Norway, Sweden and Finland have implemented the rule in a way that what was intended to be a narrow exemption may become the principal rule, while what was the principal rule of the provision, i.e. that the consumer must receive acknowledgement of the order with all relevant information regarding the contract on paper or another durable medium, may become the exemption. This may be problematic if these countries do not take a very narrow interpretation of the exemption clause for their basis.

6) It should be considered introducing independent liability for telecom providers for service providers' serious and/or repeated offence against consumers or violation of the rules on fair marketing. This might for instance be desirable in case a provider seriously offends children or in case of serious misuse of fee collection. In Sweden and Denmark there are ethical rules and agreements which oblige telecom providers to suspend co-operation with service providers who seriously and/or repeatedly violate the ethical rules. Such rules could be introduced in the Nordic countries in general to the benefit of consumer protection. 


\section{Konklusion}

Rapporten har søgt at afdække en bred vifte af de problemstillinger, der vedrører tilslutning til mikrobetalingsmidler og vedrørende den enkelte mikroaftale. Det viste sig ved en nærmere betragtning, at mikroaftaler og mikrobetalinger juridisk set kan siges at berøre meget store dele af både de offentligretlige og privatretlige regelkomplekser i de nordiske lande samt i EU-direktiverne. Dette var dog hverken ønskeligt eller hensigtsmæssigt $i$ en beskrivelse af mikroaftalerne som noget specifikt, hvorfor en afgrænsning blev absolut nødvendig. Det kan naturligvis diskuteres, om den afgrænsning, der er foretaget, er den rigtige, men en sådan er altid et udtryk for (vanskelige) valg mellem helhed, overblik, detaljeringsgrad, omfang m.m.

Det har vist sig, at de nordiske lande, med Island som en vis grad af undtagelse, også på mikroaftaleområdet stadig har en høj grad af retsenhed og retsfoellesskab. Rigtig mange af de behandlede lovområder og enkeltregler er næsten identiske - i hvert fald i deres materielle indhold - fra land til land, hvilket også skyldes, at mange af de relevante regler nu er direktivbaserede, og derfor må forventes at have en høj grad af ensartethed. Dette kan give en vis fornemmelse af deja vû ved gennemlæsning af rapporten, men for en nogenlunde fuldstændig beskrivelse af det enkelte lands retsregler og for en mulig komparativ sammenligning, har det været nødvendigt at gentage reglerne, selv om de har lignet hinanden meget.

Der har tegnet sig en række områder, hvor forbrugerbeskyttelsen enten i enkelte eller alle de nordiske lande kunne trænge til en styrkelse, idet ingen af de undersøgte lande har en lovgivning, der på alle punkter fungerer optimalt med henblik på beskyttelse af forbrugeren. Dette vil blive nærmere berørt nedenfor.

Spørgsmålet, om der kan lempes på nogle af de forbrugerbeskyttende regler af hensyn til de erhvervsdrivendes mulighed for at udvikle mikrobetalingssystemer, er vanskeligt at afgøre, idet svaret herpå blandt andet afhænger af, hvordan man forestiller sig, at mikrobetalingsområdet udvikler sig i fremtiden. Som det ser ud lige nu, er området inde $\mathrm{i}$ en rivende udvikling, og f.eks. betaling med overtakserede SMS/MMS'er kunne se ud til at være i en udvikling, der kunne gøre det til et helt nyt betalingsmiddel. Dette aspekt skærper opmærksomheden på forbrugerbeskyttelsen og maner til nogen forsigtighed. Hvis man ønsker at lempe reglerne på enkelte områder, vil det være formålstjenligt, om dette sker i et tæt samarbejde de nordiske lande imellem, således at retsenheden og retsfællesskabet bevares. Det vil også styrke samhandelen imellem de nordiske lande og forenkle forholdene både for forbrugerne og de erhvervsdrivende.

Gennemgangen af de forbrugerbeskyttende regler, der regulerer forholdene omkring mikroaftaler og mikrobetalinger har vist, at alle de nordiske lande har et stort antal forbrugerbeskyttende regler, der vedrører området. Der er generelt en høj grad af sikring af forbrugerens integritet $\mathrm{i}$ forhold til dataregistrering, ret til adgang til oplysninger og fortrydelsesret. Der er dog en række punkter, hvor der er "huller" i forbrugerbeskyttelsen:

1) Et af de største huller i beskyttelsen af forbrugerne er den manglende klare regulering af, hvad der gælder for forbrugerens hæftelse for tredjemands uberettigede misbrug af det betalingsmiddel, som en mobiltelefon med mulighed for at anvende overtakserede SMS/MMS'er kan være. Der er mulighed for, at de gældende regler om 
forbrugerens hæftelse for tredjemands uberettigede misbrug af kontokort vil blive anvendt analogt, men dette er endnu ikke afklaret i nogen af de undersøgte lande. Der mangler her ud over en beløbsgrænse for forbrugerens selvrisiko, således som dette findes vedrørende misbrug af kontokort i Danmark (1.200 kr.) og Norge (800 kr.) ikke mindst set i lyset af, at mobiltelefonen som betalingsmiddel må anses for at være et ikke-sikkert betalingsmiddel. Det er en urimeligt stor risiko at lægge på forbrugerne, såfremt der ikke opstilles klare regler for forbrugernes hæftelse for tredjemands uberettigede brug af telefonen, bedst suppleret med en grænse for forbrugerens selvrisiko, såfremt han ikke har udvist grov uagtsomhed i opbevaringen af telefonen eller ved anmeldelsen af dens bortkomst.

2) Det er en betydelig svækkelse af forbrugerens mulighed for at overskue sin juridiske og praktiske situation, at teleselskabernes kontrakter i urimelig høj grad er uoverskuelige, vanskeligt tilgængelige og uklare. Der bør arbejdes på at få teleselskaberne til at udfærdige enkle, klare og brugervenlige kontrakter, der indeholder forståelig og klar information til forbrugerne om bl.a. sikkerheden omkring brugen af mobiltelefoner, hæftelse for tredjemands misbrug, muligheden for saldokontrol og spærring for visse ydelser, opsigelse af abonnement m.v.

3) Der er et væsentligt behov fra forbrugerside (og der må formodes også at være et sådant fra erhvervsdrivendes side), for at kunne aftale saldokontrol for mobiltelefonabonnementer, ligesom der er et stort behov for at kunne spærre for muligheden af, at der kan anvendes (visse typer af) overtakserede SMS/MMS'er. I Danmark og Finland giver lovgivningen forbrugerne mulighed for at kræve en aftale om saldokontrol, men det er ikke afklaret, hvilke regler, der gælder, hvis teleudbyderen tilsidesætter sådanne aftaler og lader abonnenten overskride den aftalte overgrænse. (I Finland kan desuden man kun vælge en totalspærring for SMS/MMS og dermed også for de overtakserede, men ikke at spærre for de overtakserede SMS/MMS'er og beholde de almindelige.) Der mangler muligheden for at kunne kræve en saldoaftale i Sverige, Norge og Island. Finland og Sverige oplyser, at forbrugerne får tilbud herom på frivillig basis og mod betaling fra teleudbyderne, og Norge får muligvis indført regler herom, når forskrift til lov om elektronisk kommunikation træder i kraft. Island har ikke oplyst at have nogen planer i denne henseende. Der findes i Norge en pligt til at varsle kunden om ekstreme afvigelser i forbruget, og en sådan overvågning kan også aftales i flere af de andre lande, men dette kan ikke anses for tilstrækkelig beskyttelse af forbrugerne. Denne retstilstand medfører, at en stor gruppe forbrugere er henvist til enten at løbe risikoen ved den manglende saldokontrol/spærring, eller må tage til takke med de meget dyre taletidskort (der i øvrigt ikke er spærret for køb af overtakserede SMS/MMS'er).

4) Der mangler mulighed for, at mobiltelefonen som betalingsmiddel kan spærres med en særlig kode/kun kan åbne for telefonen som betalingsmiddel med en særlig kode. Dette ville betyde, at betalingsmidlet med overtakserede SMS/MMS'er i højere grad kunne anses som et sikkert betalingsmiddel, hvilket kunne beskytte forbrugeren mod uberettiget tredjemands brug. Det kunne endvidere styrke beskyttelsen mod, at børn anvender den voksnes lånte telefon til at købe dyre spil m.v. uden om den voksnes ønske. Det er ligeledes ønskeligt, at det sikres, at forbrugere, der ikke ønsker, at deres mobiltelefoner skal kunne anvendes som betalingsmiddel via anvendelsen af overtakserede SMS/MMS'er ikke henvises til at skulle nøjes med de meget dyre og upraktiske taletidskort. 
5) Der har ved gennemgangen af de regler, der implementerer fjernsalgsdirektivets artikel 5, stk. 2 om fritagelse for at afgive ordrebekræftelse på varigt medium vist sig at være forskelle i den måde, hvorpå de nordiske lande har gjort dette. Danmark og Island har implementeret undtagelsen i artikel 5, stk. 2 i overensstemmelse med det, der var formålet med denne, med direktivets bemærkninger om, at forbrugerne ikke bør få færre oplysninger ved handel med elektroniske kommunikationsmidler og i overensstemmelse med, hvorledes den er eksemplificeret i forarbejderne til direktivet (hvor der nævnes opkald til oplysningstjeneste). Norge, Sverige og Finland har implementeret reglen således, at det, der var tænkt som en snæver undtagelse nu kan blive hovedreglen, medens det, der var artiklens hovedregel, nemlig at der skal gives forbrugeren en ordrebekræftelse med alle til aftalen relevante oplysninger på papir eller andet varigt medium, må blive undtagelsen. Langt de fleste mikroaftaler er enkeltstående aftaler, og dermed omfattet af Norge, Sverige og Finlands undtagelsesregel, hvorefter forbrugeren ikke har krav på ordrebekræftelse ud over den, der skal gives efter e-handelsdirektivet, og som ikke skal gives på varigt medium eller i samme detaljeringsgrad. Dette må anses at være en mulighed for at udgøre et hul $\mathrm{i}$ forbrugerbeskyttelsen, såfremt disse lande ikke lægger en meget snæver fortolkning af undtagelsesbestemmelsen til grund, ikke mindst set i forhold til, hvorledes mikrobetalingerne kan udvikle sig og i forhold til, at denne undtagelse synes mindre velbegrundet, når de nye typer mobiltelefoner vinder frem.

6) Det bør muligvis overvejes, om der skal indføres et selvstændigt ansvar for teleudbyderne for tjenesteudbydernes grove og/eller gentagne krænkelser af forbrugerne eller af reglerne om god markedsføringsskik. Der findes i Sverige etiske regler, der tilsiger, at en teleudbyder skal afbryde samarbejdet med en tjenesteudbyder, der overtræder de etiske regler groft og/eller gentagne gange. Som det er nu, vil et ansvar kunne pålægges markedsføringsretligt i kraft af teleudbydernes pligt til ikke at udbyde tilbud til forbrugerne, som man erfaringsmæssigt ved, giver stor risiko for problemer for forbrugerne. 


\section{Rapportens baggrund, begreber og juridiske rammer}

\subsection{Indledende bemærkninger. Behovet for en redegørelse.}

Udviklingen på området for betalingssystemer har i de seneste år taget fart i en sådan grad, at der med jævne mellemrum dukker nye systemer op med nye muligheder for forbrugerne og de erhvervsdrivende. Overtakserede tekstbeskeder - SMS'er og MMS'er - er én af disse nyskabelser, og i denne sammenhæng tilbydes alt lige fra besked om de seneste nyheder og vejret, vittigheder, logoer, ringetoner m.v. til betaling for øl på festivals og donation til indsamlinger for nødlidende. Den udvikling vedrørende de digitale serviceydelser, der nu er i gang initieret af den teknologiske udvikling omkring de såkaldt tredjegenerations mobiltelefoner, vil formentlig medføre, at forbrugerne om kort tid vil blive tilbudt muligheden for at kunne købe sig adgang til at se en film eller læse en bog på sin telefon. Disse samlede muligheder giver på en gang behov for at kunne foretage enkle, bekvemme og billige betalinger vedrørende ret små beløb, men på den anden side også behov for, at forbrugerne kan holde kontrol med, hvad og hvor meget, der købes over telefonen eller andre via andre mikrobetalingssystemer.

En anden ny mulighed inden for mikrobetalingssystemerne er særlige koder eller chipkort, der identificerer brugeren og trækker et beløb over en konto (forudbetalt eller med løbende kredit), hver gang denne kode bruges, eller chipkortet vises. Sådanne systemer anvendes f.eks. i Danmark til betaling af broafgifter og i Finland i Helsingfors-området til betaling af bus og togbilletter. Det medium, der er bærer af chippen kan kobles til et ur, en mobiltelefon, en håndholdt datamaskine eller andet. Hvis det sættes ind $\mathrm{i}$ en mobiltelefon, kan det også få forbindelse med det mobile Internet, hvorefter, der er mulig adgang til forbrugerens bankkonto eller telefonkonto.

Formålet med denne fremstilling er at søge at afdække, dels hvilke retlige problemer, mikrobetalingssystemer giver for forbrugerne, dels hvilke barrierer og uhensigtsmæssigheder, eksisterende lovgivning udgør for udviklingen af mikrobetalingssystemer.

Målsætningen med projektet er, at det - om muligt - skal anvise løsninger på, hvorledes et rimeligt forbrugerbeskyttelsesniveau kan opretholdes samtidig med, at der kan udvikles enkle og billige mikrobetalingssystemer. Rapporten vil indeholde en beskrivelse af (eksempler på) mikrobetalingssystemers funktion og indretning, men vil ikke forsøge at angive noget mere præcist overslag over deres nordiske udbredelse. Da mikrobetalinger er et område i rivende udvikling, er en sådan vurdering af mindre betydning, idet der løbende vil komme nye aktører og nye betalingsformer til. Markedet for mikrobetalinger er i en sådan udvikling, at en opgørelse, der er blot nogle få måneder gammel, allerede kan være forældet.

Rapporten giver et overblik over gældende, relevant forbrugerbeskyttende lovgivning $\mathrm{i}$ de nordiske lande samt gældende EU-retlig regulering på området og sammenholder denne lovgivning med de barrierer for udvikling og indførelse af mikrobetalingssystemer, der antages at forekomme på det retlige område. Forbrugerbeskyttelsesmæssige 
behov beskrives og sammenholdes med gældende lovgivning, og der gøres overvejelser over, hvorvidt gældende lovgivning opfylder disse behov. Rapporten vil munde ud i forslag til ændringer i reguleringen af de nordiske landes lovgivning, der afvejer forbrugernes beskyttelsesbehov og behovet for sikre, effektive, billige og overskuelige mikrobetalingssystemer, som man frit kan vælge i forvisning om, at de ikke misbruges hverken økonomisk eller på anden måde mod udbydernes behov for at kunne udvikle enkle og billige mikrobetalingssystemer uden hæmmende indblanding fra lovgivers side. Det skal dog bemærkes, at de væsentligste barrierer for udviklingen og udbredelsen af nye betalingssystemer i dag næppe er de retlige, men snarere økonomiske, psykologiske og manglen på "kritisk masse", for at et bestemt betalingssystem kan slå igennem i konkurrencen med de mange andre, der netop nu udvikles.

De problemer, der særligt undersøges i det følgende, er:

- Forbrugerbeskyttelsesbehov i relation til aftalevilkår, oplysninger, "uagtsomt overforbrug", ansvaret for tredjemands misbrug, anvendelse af personoplysninger og særlige forhold i relation til børn og unge og

- Lovmæssige barrierer for udviklingen af mikrobetalingssystemer og for konkurrencen i forhold til erhvervsdrivende fra ikke-nordiske lande.

\subsection{Projektbeskrivelse}

Projektbeskrivelsen lyder i sammenfatning:

"Der sker en hastig udvikling i de måder, hvorpå man kan indgå aftaler om køb af varer, tjenester eller indhold, ligesom der opstår nye måder at udføre betalingen på. De store kendte internetportaler har længe haft ønske om, at kunne tage betaling for ydelser og tjenester (indhold), der via bande-reklamer på hjemmesiderne hidtil har været gratis for internetbrugerne. De traditionelle betalingstransaktioner over internettet (betalingskort) er imidlertid ikke egnede til betaling af mindre beløb (f.eks. en adresseoplysning til 2 DKK) idet transaktionsomkostningerne er for store.

Mikrobetalingssystemer kendetegnes ved, at de - på en økonomisk rentabel måde - kan håndtere betalinger af mange enheder til lav stykpris. Der findes flere virksomheder, der tilbyder mikrobetalingssystemer, så forbrugerne vil givetvis opleve flere former for mikrobetaling. F.eks. har betaling for indhold til mobiltelefonen (logoer, jokes etc.) igennem længere tid været muligt via overtakserede SMS'er. Der er store forventninger til markedet for indholdstjenester blandt markedsaktørerne, særligt i lyset af indførelsen af det mobile Internet (UMTS). Markedsaktørerne kommer fra flere brancher, og markedsaktørerne har både sammenfaldende og særegne interesser i forbindelse med handel og betalinger over Internettet. De primære aktører er de kendte internetportaler (Jubii, Yahoo, Google, KRAK, de store dagblade etc.), teleselskaberne, bankerne og indholdsproducenterne.

Ud fra et forbrugerbeskyttelseshensyn er det naturligvis problematisk, såfremt et rentabelt mikrobetalingssystem forudsætter et reduceret forbrugerbeskyttelsesniveau, herunder sikkerhed ifbm. dataoverførsler. Ligeledes er der allerede i dag kendte problemstillinger ved brugen af overtakserede SMS'ere som betaling for indhold, idet forbrugeraftalelovens regler for aftaler, der indgås ved fjernkommunikation (fjernsalgsreglerne), ofte ikke vil kunne opfyldes qua mobiltelefonens ergonomi. Det er primært den erhvervsdrivendes oplysningspligt - samt at oplysningerne skal gives på en varigt medium - det pt. er vanskeligt at opfylde på en mobiltelefon”. 
Det er under forløbet med udarbejdelsen af denne redegørelse blevet klart, at der i relation til de juridiske problemer er en skillelinje mellem forudbetalte ihændehaverbetalingssystemer (pre-paid), der bærer alle oplysninger "i sig selv" og betalingssystemer, der er knyttet til en konto med deraf følgende muligheder for registrering og kontrol af forbruger, uplanlagt (over)forbrug og tredjemands misbrug. Som eksempler på de to typer mikrobetalingssystemer kan nævnes elektroniske klippekort til bus og tog og de overtakserende SMS'ere og betaling med digital kode. De overtakserede SMS'er udgør et af rapportens væsentligste fokusområder, da der er på dette område for tiden er en stærk udvikling i gang.

Endvidere tegner der sig nogle særlige problemstillinger vedrørende børn og unge, hvorfor disse er særligt behandlet.

\subsection{Fastlæggelse af nogle begreber.}

Mikrobetalingsområdet er ikke kun i praksis, men også juridisk set et nyt område, hvor der endnu ikke er fastlagt klare og entydige begreber. Dette skal kombineres med visse klassiske juridiske begreber for at give de nødvendige redskaber til en dyberegående analyse.

\subsubsection{Realydelse og pengeydelse. Vare og/eller tjenesteydelse.}

I enhver handel (bortset fra byttehandler) indgår de to elementer realydelsen og pengeydelsen: En realydelse, som hidtil har kunnet beskrives som en vare eller tjenesteydelse, samt en pengeydelse - oftest i form af kontante penge eller elektronisk overført betaling. Digitale ydelser udgør en vanskelig mellemform, hvor det er vanskeligt at afgøre, om der er tale om en vare eller en tjenesteydelse. Dette er ikke mindst tilfældet på det område, hvor mikrobetalingerne vil have stor relevans. F.eks. kan man næppe svare entydigt på, om et musikstykke, der downloades via Internettet, er en vare eller en tjenesteydelse (medens en færdigkøbt CD er en vare og en billet til koncert er køb af en tjenesteydelse), om et kort med en ruteangivelse hentet over nettet og udskrevet $\mathrm{i}$ egen printer er en vare (som et købt vejkort) eller en tjenesteydelse (som en oplysning), om adgang til at læse en novelle, se en boksekamp eller modtage et logo eller en ringetone til mobiltelefonen er en vare eller en tjenesteydelse. Det er i visse situationer ikke lige meget, om en ydelse skal anses som en vare eller en tjenesteydelse, idet den juridiske regulering (f.eks. af beregning af fristerne for udnyttelsen af fortrydelsesretten) er afhængig af, om en ydelse er det ene eller det andet. Spørgsmålet er uafklaret, og området trænger til en juridisk kulegravning, hvor man formentlig er nødt til at træffe en række juridiske valg for den retlige regulering af de digitale ydelser. Der findes ikke nogen naturlove, der gør, at det rigtige svar kan findes blot ved at se logisk på begreberne, men der må vælges ud fra, hvilke resultater, der forekommer mest rimelige og anvendelige $\mathrm{i}$ praksis. Der må her bl.a. ses på den kommunikationsform, som ydelsen er knyttet til, således at reglerne muligvis i nogen grad må tilpasses de anvendte medier, ligesom disse medier må tilpasse sig de gældende regler. I visse situationer må digitale ydelser derfor formentlig anses som varer og i andre situationer kan det bedste resultat komme ved at rubricere de digitale ydelser som tjenesteydelser. Det kan endda være, at den samme digitale ydelse i nogle relationer skal reguleres efter de regler, der gælder for varer og $\mathrm{i}$ andre efter tjenesteydelsesreglerne. Dette problem ligger dog uden for denne rapports grænser, og der vil blot blive peget på det i visse sammenhænge. En retlig kulegravning af området kunne være gavnlig, og det kunne være formålstjenligt, om en sådan under- 
søgelse skete i et tæt nordisk samarbejde, dels for at ikke alle skal lave hele arbejdet selv (ressourcebesparende), men ikke mindst for at bevare den høje grad af nordisk retsenhed, som hersker på området.

Det må dog slås fast, at de digitale ydelser er omfattet af regler om varer og tjenesteydelser, så i de tilfælde, hvor der er forbrugerbeskyttende regler for køb af varer og tjenesteydelser, vil denne forbrugerbeskyttelse omfatte de digitale ydelser. De udgør ikke en tredje kategori uden for den gældende lovgivning.

Køb af realydelser er reguleret ved bl.a. køberetlige regler, regler om fjernsalg og regler om særlige ydelser (pakkerejser, kreditaftaler, timeshare boliger m.v.). I disse regelsæt findes en lang række forbrugerbeskyttende bestemmelser, herunder regler om oplysningspligt og i visse tilfælde fortrydelsesret.

Pengeydelsen er i langt de fleste tilfælde enten kontant betaling med sedler og mønter i fysisk handel eller elektronisk betalingsoverførsel fra debitors konto til kreditors. Den fysiske betaling i sedler og mønter (kontant pengebetaling) er ikke relevant i forbindelse med nærværende rapport ud over, at man med fordel kan holde sig retsstillingen vedrørende penge for øje for at sammenligne forskelle og ligheder i forhold til elektronisk betaling. Ved betaling med penge gælder pengereglen, dvs. at penge modtaget i god tro kan beholdes, uanset betalerens adkomst til pengene (om de f.eks. er stjålne). Pengereglen kan ikke antages at gælde i elektroniske betalingsforhold.

Pengesystemet er så indarbejdet i samfundet, at udbyderen af dette betalingssystem ikke behøver oplyse om systemets funktion og indretning i forbindelse med den enkelte forbrugers anvendelse af systemet (der i øvrigt er lovbundet ved særregler herom). Ved betaling med kontante penge er det indlysende, at pengesystemets udbyder ikke er "deltagende tredjemand" i handlen og dermed ikke kan være ansvarlig for, hvorvidt realydelsen f.eks. er kontraktmæssig, om den udbydes ved metoder, der er i strid med god markedsføringsskik eller andet. Dette gælder ikke nødvendigvis ved betaling via elektroniske betalingssystemer, da der kan være et sådant sammenfald i personkreds eller så nært et samarbejde mellem udbyderen af betalingssystemet og udbyderen af varen/tjenesteydelsen, at det kan være relevant at gøre disse parter gensidigt ansvarlige for hinandens ydelser over for forbrugeren.

\subsubsection{Betaling over telefonen}

Der findes forskellige systemer til køb af ydelser via telefonen:

En anvendelse af telefonen er køb af taletelefoni og almindelige SMS/MMS'er. Under denne kategori falder køb af informationer og indholdstjenester med integreret taksering, hvor udbyderen af telenet eller teletjenester som en integreret del af takseringen for opkald til et specielt telefonnummer tillige varetager registrering af forbruget af en bagvedliggende informations- eller indholdstjeneste samt fakturering og opkrævning for denne hos slutbrugeren (overtakserede abonnentnumre). Sådanne opkald til særlige telefonnumre er blot en særlig form for taletelefoni og indebærer ikke, at der er tale om at anvende telefonen som et særligt betalingsmiddel. Forbrugeren er ved opkald til disse særlige telefonnumre (900-numre, 800-numre m.v.) er beskyttet af særlige regler baseret på EU-direktivregulering. Taletelefoni og almindelige SMS/MMS beskeder samt opkald til særligt dyre telefonnumre er ikke omfattet af denne rapport, da de som nævnt ikke kan anses som mikrobetalinger. 
En anden anvendelse er køb af overtakserede/indholdstakserede SMS'er og MMS'er uden integreret taksering. (SMS: Short Message System. MMS: Multimedie Message System) Her betaler abonnenten normal "trafiktakst" for selve SMS/MMS'en plus et beløb (f.eks. 10 eller $25 \mathrm{kr}$.) for selve ydelsen, der kan bestå af spil, oplysninger, ringetoner m.m., der kan anvendes på telefonen, men ydelsen kan også angå køb af billetter, parkering, drikkevarer m.v.. Begge disse beløb faktureres og opkræves af teleudbyderen, men i sidstnævnte tilfælde er der reelt tale om anvendelsen af telefonen som et betalingsmiddel, hvor den købte ydelse i princippet kan være hvad som helst - både varer og tjenesteydelser.

En tredje form for anvendelse af telefonen er betalingssystemer, hvor mobiltelefonen er koblet til en mikrochips, hvorefter den kan anvendes til betaling via Visakort, via en mobil lommebog eller med forbindelse direkte med kundens bankkonto. Der kan i sådanne situationer være tale om kreditkøb, debetkøb eller kontant, forudbetalt køb.

De hidtil kendte og meget udbredte elektroniske betalingssystemer (i Danmark f.eks. Dankortet) kan anvendes til betaling af i princippet ethvert beløb - også meget små men er typisk blevet anvendt til betalinger af en vis størrelse. Betaling af meget små beløb er upraktiske i forbindelse med de hidtil kendte systemer, da de kræver en del indtastning af kortnumre, personlig kode eller digital signatur. Herudover er betaling på denne måde uforholdsmæssig dyr at håndtere, hvis det er småbeløb, betalingen angår. Dette er grobunden for udviklingen af betaling via SMS/MMS'er, idet denne betalingsform kan afvikles mere smidigt og billigere.

På denne baggrund arbejdes der på at skabe mikrobetalingssystemer, der er indrettet på at håndtere betaling af små beløb (fra $0,25 \mathrm{kr}$. og typisk 2-5-10-15 kr.) men også $50 \mathrm{og}$ $100 \mathrm{kr}$.

\subsubsection{Definition af mikrobetaling}

Begrebet mikrobetaling findes ikke defineret lovmæssigt, ligesom mikrobetalingssystem heller ikke er defineret. Betalingsmidler er defineret i dansk ret i lov om visse betalingsmidler, der alene gælder elektroniske betalingsmidler. Definitionen lyder:

"§ 1, stk. 2. Ved betalingsmidler forstås i denne lov følgende midler, i det omfang de kan benyttes til at erhverve varer eller tjenesteydelser, foranledige overførsel af beløb, hæve penge eller foretage andre betalingstransaktioner:

1) Hævekort og betalingskort, som er knyttet til bestemte brugere.

2) Andre fysiske legitimationsmidler, som er knyttet til bestemte brugere, og som er beregnet til elektronisk aflæsning.

3) Koder og biometriske værdier, som er beregnet til at legitimere brugeren.

4) Elektronisk registrerede fordringer, som udsteder er forpligtet til at indfri på brugers anmodning.

Stk. 3. Ved forudbetalte betalingsmidler forstås i denne lov betalingsmidler som nævnt i stk. 2, der tillige er

1) elektroniske penge, jf. $\S 1$, stk. 3 , i lov om udstedere af elektroniske penge, eller

2) betalingsmidler, som brugeren kun kan anvende, i det omfang der forud for anvendelsen af betalingsmidlet er sket indbetaling af midler, som ikke er registreret på en konto, der tilhører brugeren, eller hvor brugeren vederlagsfrit har modtaget en sådan værdi eller har fået forhøjet betalingsmidlets værdi”. 
Lov om betalingsmidler inddrages jævnligt i denne fremstilling bl.a. på grund af, at EUkommissionen i en henstilling fra 1997 har anbefalet, at medlemslandene indfører forbrugerbeskyttende regler vedrørende betalingssystemer. Kommissionens henstilling synes i vidt omfang at være inspireret af denne danske lov, og Kommissionen har meddelt, at hvis medlemslandene ikke giver forbrugerne den fornødne beskyttelse - navnlig for så vidt angår ansvarsregler og information om vilkår m.v. vedrørende betalingsmidler - er Kommissionen indstillet på at fremsætte et direktivforslag, således at medlemslandene tvinges til at gennemføre de fornødne regler.

Det er vigtigt at gøre sig klart, at "mikrobetalinger" (endnu) ikke er et udtryk for nogen klart defineret og særligt reguleret juridisk størrelse, men blot et samlebegreb for betaling af små beløb. Man kan fra lovgivers side derfor vælge at definere ordet mikrobetalinger, f.eks. som betalinger under et vist beløb, eller man kan undlade at have en definition og blot udforme særlige krav til sådanne småbetalinger eller give særlige lempelser herfor op til et vist beløb i forhold til gældende lovgivning. Der er som samlende faktor $i$ begrebet, at det drejer sig om elektroniske transaktioner af små beløb.

Det er set nævnt som et kriterium, at en mikrobetaling skal være en udgift, som er så lille, at personen, som køber den aktuelle tjeneste, ikke vil have særlige betænkeligheder ved at betale købet. Et sådant kriterium vil dog være for subjektivt til at kunne fungere som retlig definition, om end det peger på en af de væsentlige faktorer i mikrobetalingerne.

"Mikrobetaling" antyder, at der er tale om betaling af små beløb, og oftest anvendes ordet om mindre betalinger på 1-2-10 kr., men også betalinger på 15, 50 og $100 \mathrm{kr}$. ses omtalt som mikrobetalinger. Ved udformning af en eventuel lovregulering på området kan det vise sig hensigtsmæssigt at fastlægge en beløbsmæssig grænse for særregler på f.eks. 10 kr. pr. transaktion. Dette er dog et politisk og ikke et juridisk valg.

Sammenfattende kan det siges, at det særlige ved mikrobetalinger er, at der er tale om små beløb, hvor omkostningerne ved at foretage betalingstransaktionen er uforholdsmoessigt store, og at mikrobetalinger undertiden anvendes $\mathrm{i}$ forbindelse med et elektronisk medium, f.eks. mobiltelefoner, chipkort m.v., hvor de fysiske forhold for f.eks. umiddelbar modtagelse af oplysninger er meget begrænsede. Dette sidste er dog ikke altid tilfældet, da der også foretages mikrobetalinger via computer over Internettet, hvorved der i princippet kan gives stort set uendeligt mange oplysninger. Når de nye "tredjegenerations" mobiltelefoner bliver almindelige blandt forbrugere, vil problemet om den begrænsede mængde oplysninger ved handel med overtaksere SMS/MMS beskeder elimineres, da disse telefoner også kan vise og lagre store mængder information. De problemer, der måtte være for udviklingen af mikrobetalingssystemer vil formentlig i et vist omfang løse sig selv ved den teknologiske udvikling.

\subsection{Rapportens juridiske rammer}

Køb af realydelsen, betalingen herfor og betalingssystemet, der "bærer" betalingen er nært knyttet til hinanden i den praktiske afvikling heraf, og derfor bliver det relevant $\mathrm{i}$ sammenhæng med reglerne om mikrobetalinger at nævne lovgivning og problemstillinger, som juridisk knytter sig til realydelsen, såsom f.eks. oplysninger om varen eller ydelsen og om fortrydelsesret vedrørende købet, idet disse oplysninger skal gives senest samtidig med betaling heraf. Hvis et varekøb fortrydes, eller ikke leveres i overensstemmelse med aftalen, vil dette få konsekvenser for betalingstransaktionen (jf. i Dan- 
mark betalingsmiddellovens $\S 11$ ), idet udsteder hæfter for uberettiget anvendelse, hvilket bl.a. forstås således, at udsteder i visse situationer hæfter for, at betalingsmodtager returnerer penge efter et fortrudt køb).

Ligeledes er det relevant at se på den lovgivning, der gælder for betalingsmidler og elektronisk overførsel af penge, da dette er den anden halvdel af mikroaftaler og mikrobetalinger. Og endelig er det relevant at inddrage regler om anvendelse af persondata, da visse af disse systemer giver mulighed for at gemme oplysninger om forbrugerne. Lovgivningen om elektroniske penge inddrages dog kun i begrænset omfang, da dette ligger uden for denne rapports rammer, om end de forudbetalte elektroniske penge (småpengekort o. lign.) kan være et velegnet instrument til betaling af mikroydelser.

I denne redegørelse vil derfor indgå dels beskrivelse og analyse af betalingssystemerne og betalingsformidlingen, dels en beskrivelse og analyse af regler tilknyttet realydelsen samt regler om anvendelse af persondata.

Rapporten vil dermed omhandle mikroaftaler og ikke end blot mikrobetalinger. 


\section{Beskrivelse af mikrobetalings- systemer}

Der vil i dette afsnit blive gennemgået en (noget forenklet) fremstilling af en "mikrobetalings" faktiske forløb dels ved hjælp af overtakseret SMS/MMS-besked, dels ved hjælp af et betalingssystem (Som eksempel er valgt Valus) udviklet til brug for køb af informationsydelser over Internettet og endelig køb af transportydelse via chipkort. Der gives sideløbende en retlig beskrivelse af aktørerne i sådanne betalingstransaktioner. I den digitale verden sendes der flere meddelelser frem og tilbage mellem forbrugerens telefon/konto, tjenesteudbyderne og betalingssystemudbyderne, men det er ikke nødvendigt for denne fremstilling at gå ind i sådanne tekniske detaljer. Som eksempler anvendes:

1. Køb af en ringetone til en mobiltelefon med betaling via overtakseret SMS.

2. Køb af en informationstjeneste over Internettet ved betaling via f.eks. "Valus".

3. Betaling for en tur med bus/tog eller parkeringsafgift med betaling via chipkort.

Eksempel 1: Køb af ringetone.

1. Kunden ser en reklame, annonce eller andet, der henleder hans opmærksomhed på tjenesteudbyderens ydelse, som f.eks. kan være en ringetone.

2. Kunden sender via sit telefonselskab en SMS/MMS til tjenesteudbyderen (i det følgende kaldet indholdsudbyderen) og bestiller ringetonen, der koster $10 \mathrm{kr}$. (plus prisen for SMS'en)

3. Indholdsudbyderen sender en SMS besked med bekræftelse på, at bestilling er modtaget. Aftalen er hermed indgået og bindende juridisk for begge parter. Kunden kan herefter hente ringetonen gennem sin mobiltelefons "Vis-vælg"-funktion.

4. Kort efter modtages en besked "Ringetonen er modtaget". Denne skal gemmes på telefonen.

5. Herefter sendes besked fra indholdsudbyderen til kundens mobiltelefonselskab, og der trækkes $10 \mathrm{kr}$. over kundens abonnementsregning. Herudover betale kunden "trafikafgift", dvs. normal takst for SMS'en.

6. Hvis der er problemer med leverancen, f.eks. at der sker levering af en forkert ringetone, slet ingen levering eller indholdsleverandøren opkræver en anden pris end aftalt, kan kunden klage til sit teleselskab og til indholdsudbyderen. Spørgsmålet er, om teleselskabet herefter er forpligtet til at tilbageføre de $10 \mathrm{kr}$.

I eksemplet er med terminologien fra den danske lov om visse betalingsmidler kunden "bruger", indholdsudbyderen "betalingsmodtager" og telefonselskabet "udsteder" og "indløser" i forhold til betalingssystemet.

Eksempel 2: Køb af en informationstjeneste.

1. Kunden finder indholdsudbyders internetside. Ydelsen kan være en nyhedstjeneste, et adressekartotek, en vejviser eller lign. Kunden vælger en (eller flere) tjenesteydelse(r) herfra. Hvis indholdsudbyderen og kunden er tilknyttet, f.eks. Valus, CoinClick eller lign., vælges dette som betalingsmetode.

2. Kunden logger sig ind på Valus og åbner en brugersession, hvorefter kunden kan foretage flere køb på samme internetsite eller på flere forskellige internetsites, uden 
at behøve at logge ud og ind på sin Valus-konto. Hvert enkelt køb skal blot bekræftes.

3. Såfremt kunden ikke ønsker at have besvær med at bekræfte efter hvert køb, der ofte vil andrage ganske små beløb, kan kunden vælge et minimumsbeløb på f.eks. 5 kr., før kunden vil bekræfte køb.

4. Købet trækkes først over Valus-kontoen, når det er succesfuldt gennemført. Valussystemet tjekker først, om der er tilstrækkeligt med penge/kredit på kontoen, så beløbet kan blive reserveret. Når indholdsudbyderen har leveret tjenesten, sendes der en melding herom til Valus, hvorefter pengene frigives fra Valus-kontoen til indholdsudbyderen.

5. Systemet logger automatisk kunden af, hvis der ikke er foretaget nogen Valustransaktioner i over 20 minutter.

6. Kunden kan klage on-line, hvis den tjeneste, kunden har købt, ikke bliver succesfuldt leveret, og beløbet alligevel er blevet trukket på Valus-kontoen. I kundens kontooversigt og kontohistorik på internetadressen www.valus.dk er der en klageknap ud for hvert enkelt køb. Ved at trykke her, kan kunden sende sin klage direkte til indholdsudbyderen (forretningen), der derefter har 48 timer til at behandle klagen. Hvis indholdsudbyderen ikke behandler klagen inden for de 48 timer, vil kunden automatisk få tilbageført beløbet.

Valus-systemet oplyser ikke, hvorledes man stiller sig, hvis indholdsudbyderen nok behandler klagen, men uretmæssigt afviser f.eks. at tilbageføre et beløb, som kunden ikke burde være trukket for.

Også i dette eksempel er kunden "bruger", indholdsudbyderen er "betalingsmodtager" og Valus/CoinClick m.fl. er "udsteder" og "indløser" i betalingssystemet.

Eksempel 3: Betaling for tog-/busrejse eller parkeringsafgift ved hjælp af chipkort. Kunden erhverver et chipkort, som kan være et plastikkort af udseende som et traditionelt kreditkort, eller som kan være udformet som en anordning, der kan fastgøres på ruden af en bil, være en del af et SIM-kort til en mobiltelefon, en mini-computer eller andet. Dette chipkort kan indeholde en personlig kode, som identificerer bæreren af chippen (personen, bilen eller andet) eller være et "ihændehaverkort", der kan anvendes af enhver, der bærer det.

1. Hver gang chipkortet passerer en scanner (og en eventuel personlig kode anvendes samtidig hermed), registreres det, at der er brugt 1 enhed (en rejse, en times parkering), som fratrækkes det beløb, der forud er overført til chip'en.

2. Når det forudbetalte beløb er brugt, kan nogle chipkort "genoplades" med penge eventuelt overført fra kundens konto, medens andre ikke kan genoplades, men er "engangskort", som f.eks. taletidskort til mobiltelefoner.

3. Visse chipkort kan kombineres med Internetadgang via mobiltelefonen, hvorefter det vil være muligt at koble det til kundens bankkonto eller en konto hos tjenesteudbyderen. I så fald bør der være tilknyttet en personlig kode til sikring mod misbrug.

Hvis tjenesteyderen ikke har eget betalingssystem, vil denne være "betalingsmodtager", men hvis systemet er udbudt af tjenesteyderen selv - f.eks. busselskabet eller den erhvervsdrivende, der har overtaget administrationen af parkeringsafgiften - er forretningen også "udsteder" og "indløser" efter den i Danmark fastlagte terminologi.

Mikrobetalingssystemer kan, som det fremgår af ovennævnte eksempler, indrettes både som forudbetalte systemer, hvor der er en aftalt begrænsning i brugen eller som (forudbetalte) kontosystemer med i princippet ubegrænset adgang til at trække på kundens 
konto med deraf følgende risiko for eget, uplanlagte overforbrug eller tredjemands misbrug af kontoen. Ved forudbetalte systemer uden mulighed for optankning eller overtræk lukkes der for kundens dispositionsmuligheder, når det forudbetalte beløb er brugt som f.eks. ved taletidskort og elektroniske busklippekort.

Dette forudsætter dog, at systemet ikke administreres, således som visse teleselskaber administrerer taletidskort: Når taletiden er udløbet, registreres merforbruget, og når kunden sætter det næste taletidskort i telefonen, trækkes merforbruget straks fra værdien af det nye taletidskort. Dette kan på den ene side ses som en service over for kunden, som ikke får sin telefonforbindelse afbrudt på et ubekvemt tidspunkt. På den anden side anvendes de dyre taletidskort netop ofte af kunder, som ønsker at styre deres forbrug på denne måde. For dem kan det komme som en ubehagelig overraskelse, at de på denne måde har stiftet gæld/overskredet budgettet.

Hvor mange transaktioner, der faktisk finder sted ved en forbrugers on-line køb af en indholdsydelse over Internettet ses illustreret i nedenstående diagram (som i øvrigt ikke forklares yderligere). Diagrammet findes i Rasmus Christiansen og Mikael W. Koch Hansens uddrag af kandidatafhandling om mikrobetalingsmarkedet i Danmark: Mikrobetalinger, Handelshøjskolen i København, august 2002, afsnit 6.4.1.1.

VTS-diagram og flowbeskrivelse i CoinClick.

En betaling i CoinClick gennemføres i følgende trin:

1. Betalingen initieres af en forbruger. Ved et klik på en informationsydelse hos indholdsleverandøren sendes betalingsanmodningen (Authorize-req) til CoinClick. Linket indeholder information om varens pris og URL til informationsydelsen, m.v.

2. CoinClick beder forbrugeren indtaste brugernavn og password for at autentificere forbrugeren. Ved korrekt indtastede oplysninger undersøger Coin-Click, om der er dækning på betalingskontoen.

3. CoinClick returnerer derefter til forbrugerens browser den URL, hvorfra informationsydelsen kan hentes. Desuden medsendes som parameter et transaktionsnummer (CBTRX) og en checksum (CBCS).

4. Indholdsleverandøren modtager anmodning om levering af informationsydelsen og checker hos CoinClick det medsendte transaktionsnummer og checksummen. Hvis CoinClick kan konstatere, at transaktionsnummer og checksum er gyldigt, sendes ok tilbage til indholdsleverandøren. Varen kan leveres.

5. Ved endt levering kalder indholdsleverandøren 'capture'-funktionen hos CoinClick, som derefter flytter pengene fra forbrugerens konto til indholdsleverandørens opsamlingskonto. 


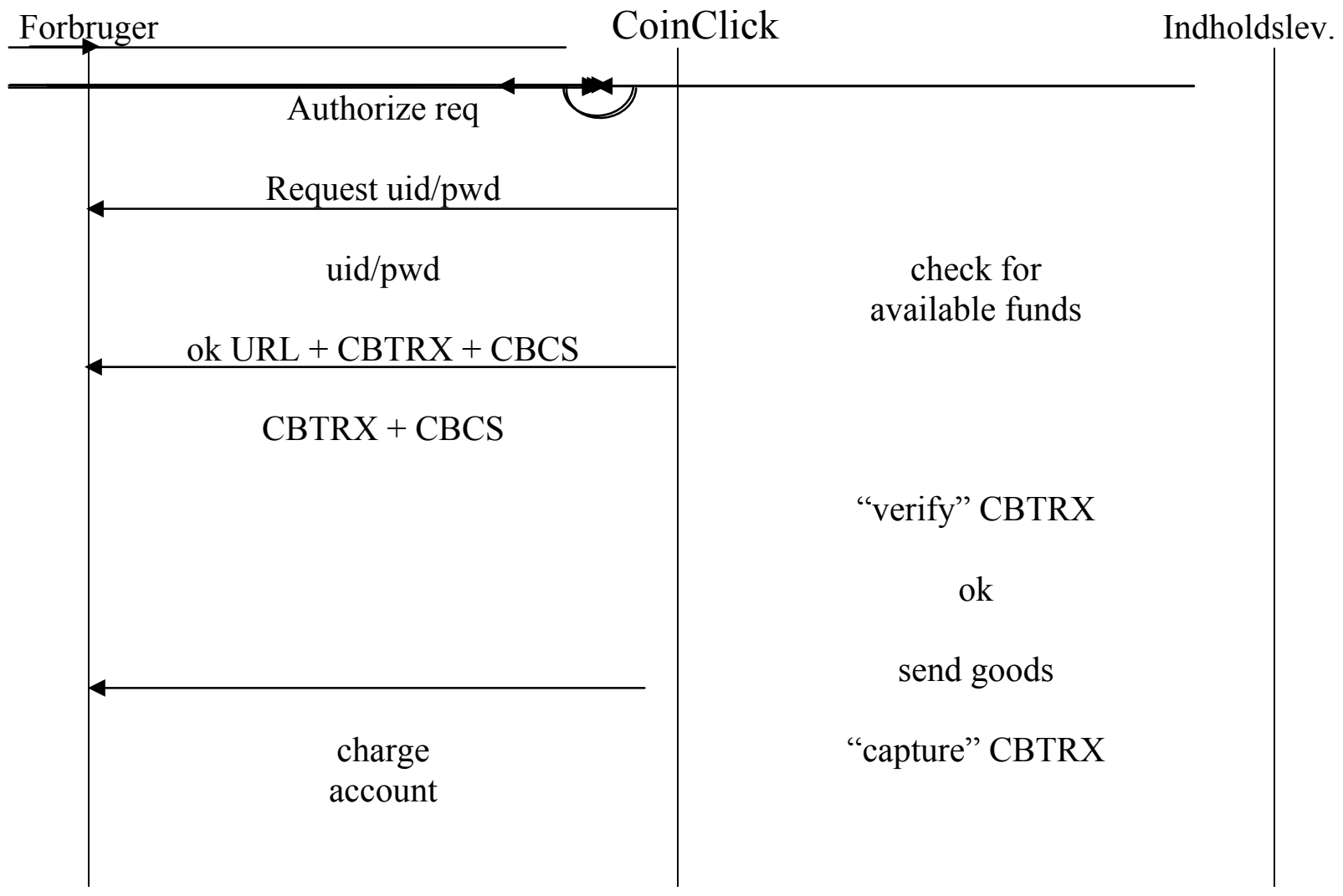




\section{Aftalens parter}

Ved aftaler betalt med elektroniske betalingsmidler er der ofte tre (eller flere) parter involveret: Der er 1) kunden (forbrugeren), 2) leverandøren af varen/tjenesteydelsen og 3) leverandøren af betalingssystemet. Dette 3 . led kan bestå af både en udsteder og en indløser, eller udsteder og indløser kan være samme juridiske person. Ved kontosystemer med eget betalingssystem tilknyttet er betalingsmodtager og udsteder sammenfaldende: Vareleverandøren og betalingsmiddelleverandøren er den samme og må opfylde de lovmæssige krav i begge relationer.

Evt. indløser

(f.eks. bank i det danske Dankortsystem)

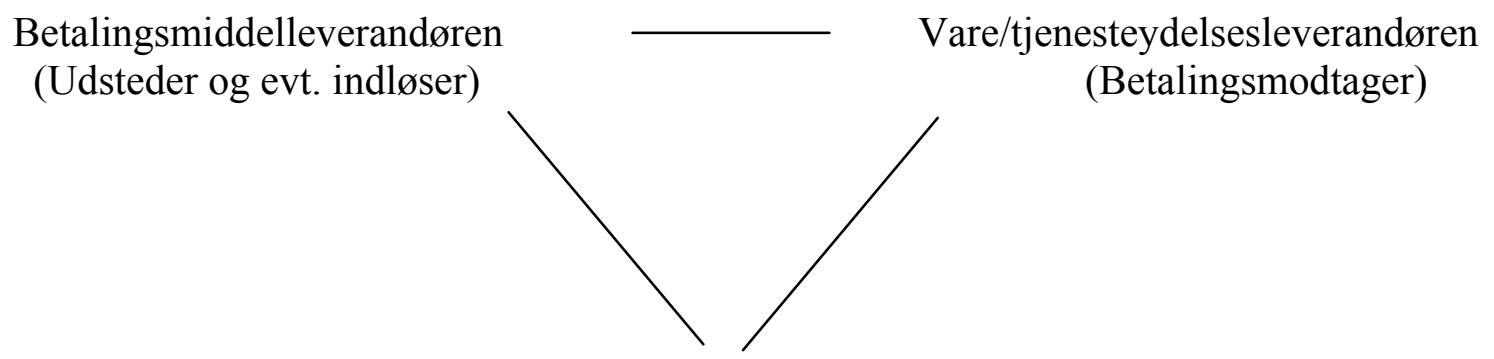

Forbrugeren

(Bruger)

Antallet (og arten) af parter i mikroaftaler afspejler naturligvis det enkelte betalingssystems indretning. Ved "interne mikrobetalingssystemer", hvor udbyderen af betalingssystemet er identisk med udbyderen af varen/tjenesteydelsen, vil der kun være to parter i aftalen, forbrugeren og én erhvervsdrivende, men der vil være tale om to aftaler, der aktiveres samtidigt. Dels en aftale om erhvervelse af en realydelse og prisen for denne, dels en (tidligere indgået) aftale om tilslutning til eller benyttelse af betalingssystemet, hvad enten dette er indrettet som en aftale om en konto med løbende kredit, er en forudbetalt konto eller et betalingsbevis i form af en mikrochip eller anden form for "elektronisk klippekort". I sådanne aftaler er der ikke tvivl om, at den samme erhvervsdrivende er ansvarlig for såvel realydelsen som betalingssystemet og dets indretning, og at dette gælder både i privatretlig og offentligretlig henseende. (Som eksempel herpå kan nævnes elektroniske bus/flybilletter

Ved betaling via "eksterne betalingssystemer" - dvs. med betalingssystemer, der er udbudt af en anden end den, der udbyder varen/tjenesteydelsen - kan sådanne systemer anvendes ved køb hos flere forskellige sælgere. Dette gælder, f.eks. Valus, CoinClick, overtakserede SMS/MMS'er og almindelige betalings- og kreditkort, og i sådanne handler er der flere separate aftaler med flere end to parter involveret. Der er dels aftalen om realydelsen, dels forbrugerens aftale med betalingssystemudbyderen og endelig en aftale 
mellem de to erhvervsdrivende om tilslutning til systemet (samt muligvis yderligere mellemkommende led, såsom disses pengeinstitutter. Se skema s. 12).

Disse aftaleparter er i dansk ret (lov om visse betalingsmidler i § 3) defineret i lov om betalingsmidler. Den, der indgår aftale med udsteder om brug af et betalingsmiddel, eller den, der i forhold til udsteder er retmæssig bruger af et forudbetalt betalingsmiddel defineres som bruger.

Ved udsteder forstås den, som brugeren indgår aftale med om udstedelse eller anvendelse af et betalingsmiddel.

Ved indløser forstås den, som indgår aftale med betalingsmodtagere om tilslutning til betalingsmidlet.

Ved betalingsmodtager forstås den, hos hvem brugeren kan anvende betalingsmidler til at erhverve varer eller tjenesteydelser, foranledige overførsel af beløb eller foretage andre betalingstransaktioner.

I Dankortsystemet, som er meget udbredt i Danmark, er PKK (Pengeinstitutternes KreditKort A/S) udsteder af Dankortsystemet, pengeinstitutterne er indløser, forretninger m.v. er betalingsmodtager, og den, der anvender Dankortet, er bruger.

I et mikrobetalingssystem med betaling via overtakserende SMS/MMS er teleselskabet udsteder og indløser, indholdstjenesteudbyderen er betalingsmodtager, og kunden er bruger.

Den retlige regulering af forholdet mellem betalingsmiddelleverandøren og vare/tjenesteydelsesleverandøren ligger ud over denne fremstillings rammer, som har fokus på forbrugerne og disses retlige relationer til de erhvervsdrivende. Det vil dog blive diskuteret, i hvilket omfang disse erhvervsdrivende kan have et ansvar for hinanden i relation til forbrugeren og i forhold til myndighederne. Se nærmere herom kapitel 4.

Forholdet mellem forbrugeren og betalingsmiddeludbyder er reguleret af bl.a. markedsføringslovgivningen, og herudover gælder en række særlove bl.a. om persondata og i Danmark bl.a. Lov om betalingsmidler. Forholdet mellem forbrugeren og vare/tjenesteyder (spørgsmålet om, hvad der er aftalens rette ydelse) er reguleret af en lang række privatretlige og markedsføringsretlige regler.

I relation til mikrobetalinger ved hjælp af SMS'er og MMS'er gælder herudover telelovgivningen, der bl.a. regulerer forholdet til slutbrugeren. 


\section{Indgåelsen af mikroaftaler og aktø- rernes ansvar for egne og andres ydelser}

Når realydelsesaftalen skal bedømmes, gælder de privatretlige regler om aftalers indgåelse og indhold. Dette gælder, f.eks. vedrørende vedtagelse af aftalevilkår, aftalers ugyldighed, køberetlige mangler, herunder sammenhængen mellem prisen og varens kvalitet. Herudover skal den erhvervsdrivende opfylde offentligretlige forskrifter bl.a. om at overholde god markedsføringsskik, undlade at vildlede, og at der skal gives de fornødne oplysninger til forbrugeren.

Spørgsmålet om god markedsføringsskik kan også omfatte betalingsbetingelser og -muligheder, og i grelle tilfælde formentlig også om den erhvervsdrivende har valgt et betalingssystem, der i betydelig grad ikke fungerer hensigtsmæssigt.

Udbyder af betalingssystemet er aftaleretligt ansvarlig for den aftale, der indgås vedrørende brugen af selve betalingssystemet, herunder ansvarlig for at kunne dokumentere, hvad der er vedtaget og aftalevilkårenes rimelighed. Hvis der til aftalen er knyttet en kreditmulighed, er den erhvervsdrivende også forpligtet efter lovgivningen om kreditaftaler, hvilket bl.a. indebærer en pligt til at give en række oplysninger før indgåelsen af selve kreditaftalen, vedrørende den enkelte betalingstransaktion og om kontoens løbende status. (Se herom under de enkelte landes nationale lovgivning).

I offentligretlig henseende er udbyderen af betalingssystemer ansvarlig for overholdelse af markedsføringslovgivningen, hvilket bl.a. indebærer, at systemet skal være indrettet overskueligt og sikkert for forbrugeren.

Spørgsmålet er, om de erhvervsdrivende i forhold til forbrugeren eller offentlige myndigheder ud over ansvaret for egne og ansattes handlinger, er ansvarlige helt eller delvist for hinandens ydelser? Kan udbyderen af betalingssystemet gøres ansvarlig for, at realydelsesleverandørens ydelser udebliver eller er af ringe kvalitet, når der er betalt for ydelsen, eller for, at der af vare/tjenesteydelsesleverandøren anvendes metoder, som må anses for at være i strid med god markedsføringsskik? Og kan omvendt realydelsesleverandøren gøres ansvarlig for, at betalingssystemet ikke fungerer korrekt eller er indrettet i strid med markedsføringslovgivningen? Disse spørgsmål vil denne fremstilling søge at finde svarene på og give nogle bud på, hvordan den retlige regulering ud fra et forbrugerbeskyttelsessynspunkt bør være.

Det kan allerede her nævnes, at udbyderen af betalingssystemet (udsteder, operatør m.v.) i medfør af den danske lov om betalingsmidler hæfter for f.eks. manglende leverance, manglende tilbagebetaling ved anvendelse af fortrydelsesretten ved at nægte at modtage varer, konkurs og andre uregelmæssigheder hos betalingsmodtager, når et elektronisk betalingsmiddel er blevet anvendt i forbindelse med fjernsalg.

Det danske Teleklagenævn behandler klager over, at kunden er debiteret for en ydelse, man ikke har modtaget, men det er tvivlsomt, om kunden også kan klage over indholdet af ydelsen (f.eks. at et spil, man har betalt for, ikke virker) 
En række teleselskaber, der udbyder mobiltelefoni i Danmark (Orange, Sonofon, TDC, Mobil, Tele 2 og Telia Mobil), har indgået en aftale om taksering af visse former for betalingsformidling via SMS, hvori man forpligter sig til at sikre, at tjenesteudbyderen af tillægstakserede SMS-tjenester, som kan betegnes som konkurrencer, udformer tjenesten således, at slutkunden højst kan deltage ved at afsende op til 12 SMS'er pr. abonnentnummer pr. dag pr. tjeneste, og at konkurrencen højst må give anledning til en tillægstaksering på 12 kr. pr. abonnentnummer pr. dag pr. tjeneste.

Ved almennyttige indsamlinger skal aftalens parter sikre, at tjenesteudbyderen udformer tjenesten således, at slutkunden kun kan deltage én gang i samme indsamling pr. abonnentnummer pr. dag og med maksimalt $150 \mathrm{kr}$. pr. dag.

Generelt forpligter aftalens parter (teleselskaberne) sig til at indgå aftale med tjenesteudbyderen på vilkår, der bl.a. indeholder de bestemmelser, der er angivet i aftalen. Disse bestemmelser er bl.a. vedrørende indholdet af SMS-tjenesterne, at de ikke må være uegnet for børn under 16 år, og at de ikke må indeholde:

- $\quad$ Beskrivelse af seksuelle eller erotiske forhold.

- Kontaktformidling med henblik på seksuelt samvær eller andre elementer heraf.

- Henvisning til andre tjenester eller links med seksuelt eller erotisk indhold.

- Beskrivelser af vold.

- $\quad$ Spil, præmiekonkurrencer og lignende i strid med gældende lovgivning.

- Adgangstegn, passwords eller lignende, der giver adgang til tjenester med ovenstående indhold.

Endelig gælder det generelt, at tjenesteudbyderen ved markedsføring af tillægstakserede SMS-tjenester skal overholde gældende lovgivning, herunder Markedsføringsloven og Forbrugeraftaleloven.

De erhvervsdrivendes ansvar for hinandens markedsføringsmæssige adfærd eller for at samarbejde med en anden erhvervsdrivende, der ikke optræder i overensstemmelse med gældende ret og god norm, kan tænkes, hvor der er et vist samarbejde mellem udbyder og betalingsmodtager om selve salgskonceptet, eller hvor udbyder har erfaret, at betalingsmodtager anvender salgsmetoder eller aftalevilkår, som er i strid med lovgivningen. Betalingsmiddelleverandøren kan således i visse tilfælde gøres ansvarlig for indholdsudbyderen/tjeneste-leverandøren i markedsføringsmæssig henseende og må kunne pålægges enten at sørge for, at indholdsudbyderens/tjenesteleverandørens forhold bringes i overensstemmelse med gældende lovgivning eller at afbryde samarbejdet med denne. Som eksempel herpå kan tænkes situationer, hvor indholdsudbyderen i forhold til mindreårige markedsfører ydelser med indhold bestående af sex eller vold, eller at en indholdsudbyder sælger ydelser, der medfører virus. Hvis betalingsmiddelleverandøren (f.eks. et teleselskab) ikke enten sørger for, at indholdsudbyderen bringer forholdene i orden eller afbryder sit samarbejde med indholdsudbyderen, vil betalingsmiddelleverandøren kunne pådrage sig et ansvar for egne handlinger, nemlig sit samarbejde med en underlødig aftalepartner og dermed medvirken til overtrædelse af gældende lovregler.

Det ville dog i forbindelse med den voldsomme udvikling på området for overtakserede SMS/MMS'er styrke forbrugerbeskyttelsen væsentligt, såfremt der pålægges teleselskaberne et direkte, privatretligt ansvar overfor forbrugerne for tjenesteydernes fejl og misbrug. Dette ville skærpe teleselskabernes opmærksomhed overfor nye tjenesteydere og støtte udviklingen af teknologi til beskyttelse mod misbrug af forbrugerne. 


\section{Aktører og interessekonflikter}

\subsection{Indledning}

Udviklingen på mikrobetalingsområdet med dets store muligheder for at opdyrke nye markeder og effektivisere gamle har givet næring til en skærpelse af interessekonflikterne blandt aktørerne på området.

Tidligere var det (i store træk) pengeinstitutterne, der formidlede betalingstransaktioner, og vare- og tjenesteudbyderne, der handlede med varer og tjenester. Hertil kom teleselskaberne, der solgte samtaler og - i begrænset omfang - visse services som f.eks. oplysninger. Indførelsen af EDB og Internettet, udbredelsen af mobiltelefoner med anvendelsen af SMS'er og udviklingen af mulighederne i mikrochips har ændret denne situation, således at der er skudt helt nye typer virksomheder frem, som sælger ydelser, der hverken er varer eller tjenesteydelser, teleselskaberne har udviklet deres udbud og ydelser, og der er erhvervsdrivende, der hidtil ikke har beskæftiget sig med betalingsformidling, men som nu udvikler egne betalingssystemer. Hertil kommer den stærkt øgede distancehandel, som udgør en væsentlig forøgelse af den enkelte erhvervsdrivendes geografiske rækkevidde.

\subsection{Internetbaserede betalingssystemer}

Udbyderne af mikrobetalingssystemer på Internettet, består dels af pengeinstitutter, der tilbyder elektronisk betaling via forbrugerens sædvanlige konto samt et nyudviklet småpengesystem beregnet til "fjernbetaling", CoinClick, dels af en række erhvervsdrivende, der enkeltvis eller i samarbejde med andre (lignende) erhvervsdrivende udbyder betalingssystemer, og endelig erhvervsdrivende, der ikke selv har betalingssystemer, men som tilslutter sig andres - primært pengeinstitutternes. Der er således ved at udvikle sig en uoverskuelig "underskov" af betalingssystemer. (Som eksempel kan nævnes Valus, som er en række medievirksomheders system og "svar" på pengeinstitutternes elektroniske småpengesystem, og udviklet bl.a. til betaling for oplysninger, nyheder, spil m.v. over Internettet). Betaling via overtakserede SMS-tjenester vil også kunne findes ved ydelser, købt over Internettet, da de nyeste telefoner kan tilknyttes det mobile Internet.

Baggrunden for udviklingen af de mange nye betalingssystemer er dels, at der er penge at tjene direkte ved betalingsformidling, men også i nogen grad, at man kan skabe en kundebinding/kunde-loyalitet ved hjælp af betaling med egne betalingssystemer: Hvis kunden har en konto ved f.eks. en elektronisk avis eller ved en adresseoplysningsudbyder, er det nemmere at blive her frem for at gå over til en anden avis/en anden udbyder, hvor der skal betales med andre, eventuelt mere besværlige betalingsmidler.

En anden væsentlig årsag til udviklingen er "kampen om gebyrerne". Således er Valus ifølge oplysningerne over dets hjemmeside udviklet som reaktion på pengeinstitutternes gebyrpolitik. Udbyderne af Valus-systemet (FDIM - Foreningen af Danske Internet Medier) ønsker at undgå risikoen for, at pengeinstitutterne opkræver gebyrer ved hver 
transaktion, og de ønsker kontrol med udgifterne ved systemet og at få del i overskuddet ved mikrobetalinger.

\subsection{Overtakserede SMS/MMS-systemer via teleselskaberne}

Ved overtakserede SMS/MMS-systemer er aktørerne en mobiloperatør, en tjenesteudbyder og en slutkunde, hvor slutkundens primære og vigtigste kontraktpartner er mobiloperatøren, hvorigennem både mobilabonnementet og købet af indholdsydelser afregnes. Mobiloperatørerne udgør en selvstændig interessepart på markedet uafhængig af pengeinstitutterne. Udviklingen af brugen af de overtakserede SMS/MMS'er udgør et meget stort potentiale, idet der her ikke er de samme barrierer for brugerne i form af følelse af fremmedhed overfor ny teknologi eller uvilje mod at lære sig brugen af et nyt medium, og ingen problemer med "kritisk masse", da stort set de fleste forbrugere allerede har en mobiltelefon.

\subsection{Andre betalingssystemer}

Betalingssystemer baseret på plastickort, chipkort eller andet mikrochipbaserede medier, kan udvikles uafhængig af andre interessenter på mikrobetalingsmarkedet af enkelte tjenesteudbydere som "internt" betalingssystem, f.eks. til betaling af bus og tog til et transportselskab, af bro- og vejafgifter, af parkering i et afgrænset område eller flere parkeringsområder, tilknyttet samme selskab, af vaske- og badefaciliteter på en campingplads, af mad og drikkevarer på en festivalplads og lign. Sådanne systemer kan udbydes både af den enkelte erhvervsdrivende og af en flerhed af tjenesteudbydere.

\subsection{Interessekonflikter mellem udbyderne af mikrobetalings- systemer.}

De enkelte mikrobetalingssystemer vil formentlig have hver sit marked og niche, afhængigt af, hvor dyrt det vil være at udvikle og drive dem, og hvilket held, man vil have med at få forbrugerne gjort fortrolige med anvendelsen af dem. Den væsentligste interessekamp omkring udviklingen af mikrobetalingsmarkedet og dermed også omkring udviklingen af retsregler, der er tilpasset det enkelte betalingsmiddels ergonomi, vil formentlig komme til at stå mellem teleselskaberne og pengeinstitutterne. Overtakserede SMS/MMS'er kan udvikle sig til et helt nyt, generelt anvendeligt betalingsmiddel for så vidt angår en lang række af hverdagens mindre betalinger i det omfang det lykkes at overvinde de retlige og praktiske/psykologiske barrierer, der på nuværende tidspunkt findes herfor. Dette aspekt sætter fokus på behovet for (at fastholde) et højt forbrugerbeskyttelsesniveau. 


\title{
6 Identifikation af de retlige problemer vedrørende mikroaftaler og - betalinger
}

\subsection{Generelt: Hvad gør, at der er særlige problemer ved mikro-aftaler}

Udviklingen og udbredelsen af mikrobetalingssystemer møder forskellige problemer og barrierer, hvoraf kun den retlige barriere er genstand for denne redegørelse.

\begin{abstract}
De praktiske, økonomiske og psykologiske barrierer findes beskrevet andre steder, bl.a. i en rapport af Rasmus Christiansen og Mikael W. Koch Hansen: "Mikrobetalinger", fra Handelshøjskolen i København, august 2002, hvor der bl.a. anføres, at svigtende annonceomsætning på Internettet har nødsaget indholdsleverandøren til at satse på mikrobetalinger som supplement hertil. Det anføres dog, at det kræver store investeringer at udvikle mikrobetalingssystemer, og at forbrugeren viser dels ringe betalingsvillighed $\mathrm{i}$ forhold til indholdsydelserne på Internettet, dels i det hele taget ikke er så interesseret i mikrobetalingsmulighederne endnu. Der er dermed store barrierer omkring det psykologiske aspekt og i at opnå "kritisk masse" - dvs. en tilslutning til et betalingssystem, der gør det attraktivt for brugerne og de erhvervsdrivende at tilslutte sig til systemet og økonomisk rentabelt at udbyde og drive det.
\end{abstract}

I august 2002 var i Danmark Valus og CoinClick de eneste væsentlige mikrobetalingssystemer tilknyttet Internettet i Danmark.

Rapporten omhandler kun Internetbaserede mikrobetalinger for informationsydelser og dermed ikke problemerne omkring de overtakserede SMS/MMS'er.

Mikroaftaler og mikrobetalinger er retligt set ikke forskellig fra andre aftaler og betalinger. Aftalens genstand er en vare eller tjenesteydelse (indholdsydelse), og betalingen foregår elektronisk, således som så mange andre betalinger i dag. Derfor gælder også, som tidligere nævnt, lovgivningen vedrørende køb, fjernsalg, kreditaftaler, markedsføring, persondata m.v. for disse aftaler.

Når dette er sagt, må det dog også konstateres, at mikroaftalerne og mikrobetalingerne har nogle faktiske scerprceg, der muligvis giver behov for en særlig retlig regulering af forholdene.

Det første særpræg ved mikroaftalerne og -betalingerne er, at de vedrører småbeløb, ofte på $10 \mathrm{kr}$. og derunder. Økonomien i disse aftaler beror derfor på både for realydelsesleverandøren og betalingssystemudbyderen (og for forbrugerne, hvis de skal betale for at anvende systemet - og det skal de jo på den ene eller den anden måde), at der indgås et stort antal af sådanne aftaler, og at de er billige at håndtere.

Hvis der skal udføres flere/mange transaktioner pr. aftale, f.eks. vedrørende oplysninger, som den erhvervsdrivende er forpligtet til at give forbrugeren, og sådanne transaktioner er forbundet med omkostninger af ikke helt ubetydelig størrelse (f.eks. på grund af gebyrer til teleselskabet, pengeinstitutterne eller anden betalingsmiddeludsteder), finder vare og tjeneste-/indholdsudbyderne det vanskeligt at få en økonomisk bæredygtig forretning ud af denne type handler. De erhvervsdrivendes behov for et meget enkelt 
og billigt betalingssystem kan derfor være i modstrid med forbrugernes retlige behov for oplysninger og sikkerhed.

Et andet særpræg ved mikroaftalerne er de medier, der anvendes til indgåelsen af aftalerne: Ved overtakserede SMS/MMS-beskeder er det mobiltelefonen, der er det elektroniske medie, og ved Internethandel er det computere af forskellig art (i fremtiden også mobiltelefoner tilknyttet det mobile Internet), medens det ved forskellige mikrochipbaserede betalingssystemer kan være plastickort, emblemer, klistermærkater, armbånd, lommecomputere eller andet, der gør brugeren i stand til at identificere sig over for systemet.

Disse medier frembyder forskellige muligheder (og for visse: mangel på samme) i forhold til at give brugeren oplysninger om selve tilslutningsaftalerne og om den enkelte handel og en eventuel fortrydelsesret og forskellige muligheder og problemer vedrørende sikkerhed mod tredjemands misbrug:

Mobiltelefonen i den udgave, der for tiden er den mest almindelige, giver begrænsede muligheder for både forudgående og efterfølgende oplysninger, idet den indtil videre kun giver teknisk mulighed for at modtage og vise en mindre mængde tegn pr. SMS, og kun kan gemme en mindre mængde af informationer ad gangen. (Når tredjegenerationsmobiltelefonerne bliver det almindelige, vil denne begrænsning forsvinde, idet disse telefoners lagerkapacitet og muligheder for at vise megen tekst ad gangen er betydelig.) Handel via mobiltelefon ved hjælp af overtakserede SMS'er kan dog eventuelt kombineres med Internettet, således at brugeren kan modtage nogle af oplysningerne, som han ikke nødvendigvis behøver have lige i købsøjeblikket, over sin e-mailadresse, eller oplysningerne kan lægges på en dertil indrettet side på Internettet, der efter omstændighederne, (dvs. hvis den indrettes, så den ikke kan ændres af nogen af parterne og kan lagres/printes ud af kunden) kan betragtes som et varigt medium i relation til bl.a. reglerne om oplysninger i fjernsalg. Endvidere kan vare/tjeneste/indholdsudbyderen supplere med henvisning til en hjemmeside, hvor man kan identificere de anvendte koder, hvem der er indholdsudbydere på nummeret, hvilket teleselskab, der er ansvarligt, hvad tjenesterne koster, hvordan man framelder sig, hvordan og hvortil man kan klage m.v. Tjenesteudbyderen kan ved at kræve oplysning om brugerens e-mailadresse hermed sikre sig, at brugeren har adgang til disse oplysninger. Se nærmere herom under de relevante afsnit under de enkelte lande.

Hvis en mobiltelefon kommer i tredjemands besiddelse, kan den anvendes til misbrug af ejerens konto, indtil denne spærres. Dette giver behov for at kunne følge med i kontoen og eventuelt at kunne spærre for visse ydelser/forbrug over en vis grænse.

Mikrobetalinger over Internettet byder på alle muligheder for, at brugeren får de relevante og lovmæssige oplysninger før, under og efter en handel. Her er problemerne ikke praktiske/fysiske, men alene hvor mange ressourcer, den erhvervsdrivende skal investere i systemet. Det er endvidere et spørgsmål, om forbrugeren er interesseret i at modtage en stor mængde informationer for hvert lille køb, der er foretaget, eller om man hellere vil nøjes med, at muligheden for at kontrollere sit forbrug eller sit kontoudtog foreligger.

Internetkonti kan misbruges, såfremt en uvedkommende kan hacke sig ind på kontoen eller kommer i besiddelse af et eventuelt password/pin-kode. Derud over kan betalingsmodtager kræve mere end aftalt for ydelserne, undlade at levere og alligevel kræve betaling eller på anden måde uretmæssigt afkræve forbrugeren penge. 
Mikrochips og andre former for elektronisk ladede kort anvendes ofte til forudbetalte (pre-paid) systemer. Mikrochippen indeholder information om, at kortet - eller hvor chippen nu er placeret - er "ladet med" en vis værdi. Ved de såkaldte "smart-cards" er der tilknyttet en kode, således at kun kortindehaveren kan anvende det. Kortet kan dog også være et "ihændehaverkort", således f.eks. telekort, elektroniske bus- eller metrobilletter, småpengekort m.v. Der er ofte tale om relativt lave beløb som maksimum på chipkortene, f.eks. op til 1.500 kr., men i Norge kan der lagres op til 10.000 kr. på SIMkortet, hvorefter behovet for beskyttelse mod uberettiget tredjemand bliver væsentligt.

Sådanne forudbetalte kort er i Danmark omfattet af lov om betalingsmidler og i alle lande af lovgivningen om elektroniske penge.

Ved forudbetalte kort uden mulighed for online "optankning" af penge begrænses en række af de juridiske problemer, idet brugeren får begrænset mulighed for at overforbruge, ligesom tredjemands misbrug også begrænses til maksimum kortets værdi, forudsat der ikke er nogen mulighed for at trække beløb ud over kortets maksimum.

Ved "ihændehaverkort" med et forud indlæst maksimum er der ikke mulighed (og næppe noget stort behov heller) for at give brugeren kontoudskrifter, der viser, hvor og hvornår kortet er brugt, men der vil i mange tilfælde være mulighed for at vise kortets saldo ved hvert brug.

Disse forholdsvist simple forudbetalte kort er ikke sikret mod tredjemands misbrug, idet der er tale om ihændehaverkort, hvor kortet er bærer af fordringen, således at den, der præsenterer kortet, formodes at være berettiget til at bruge det, og det er ikke muligt at spærre kortet. Til gengæld er brugerens risiko begrænset af kortets indestående. Kortet minder om rede penge, hvor brugerens sikkerhed mod tredjemands misbrug ligeledes består $\mathrm{i}$ at passe godt på sine ting, og hvor man heller ikke får tilsendt oplysning om, hvorledes man har brugt pengene. De frembyder dermed ret få juridiske problemer, men der er dog det særlige problem vedrørende tilbagebetaling af forudbetalte kort, såfremt hele det forudbetalte beløb ikke ønskes anvendt eller udstederen går konkurs eller lukker inden hele beløbet er brugt.

\subsection{Behov for oplysninger}

\subsubsection{Forudbetalte systemer uden konto - "ihændehaverkort" (småpengekort, elektroniske billetter m.v.)}

Forudbetalte ihændehaverkort uden adgang til nogen løbende konto udgør en (mindre) del af mikrobetalingerne.

Ved sådanne systemer med relativt lille disponibelt beløb er forbrugerens behov for detaljeret opgørelse over brugen af kortet ikke så stort som ved konto. Oplysning om saldo på kortet er dog af væsentlig interesse og kan teknisk set eventuelt gives enten direkte ved den enkelte indløsning eller ved centralt placerede "læsere".

Ved forudbetalte systemer ved ihændehaverkort har brugeren forud for tilslutning til betalingssystemet behov for at vide, 1) hvem man indgår aftale med, og eventuelt hvilken geografisk og anvendelsesmæssig udbredelse kortet dækker, 2) hvad det koster at anvende betalingsmidlet 3) om/hvorledes et eventuelt overskydende beløb kan refunderes og 4) hvor der kan klages ved uregelmæssigheder i systemet. (Dette sidste krav bør også opfyldes i forbindelse med den enkelte transaktion). 
Under brugen af sådanne forudbetalte betalingsmidler har brugeren som minimum behov for løbende at få oplyst saldo på sin "kort" hver gang, der trækkes på kortet, eller ved et af brugeren valgt beløb (f.eks. hver gang der er brugt 5 eller $10 \mathrm{kr}$.).

\subsubsection{Mikrobetalinger med løbende konto}

I sådanne betalingssystemer har brugeren ud over de oplysninger, som er nævnt ovenfor $\mathrm{i}$ afsnit 6.2.1., yderligere brug for oplysning om 5) systemets sikkerhed og beskyttelsen mod tredjemandsmisbrug og for 6) en eller anden form for kvittering for eller registrering af det enkelte træk på kontoen og 7) kontoudskrifter, som bør komme inden for et kortere tidsrum, således at brugeren får en reel mulighed for at kontrollere sin konto og sit forbrug og bl.a. sikre sig mod tredjemands misbrug.

\subsection{Sikkerhed mod tredjemands misbrug}

Brugeren (og betalingsmodtageren) har i et vist omfang og i nogle sammenhænge behov for betalingsmiddelsystemer, der er sikret mod tredjemands misbrug.

Tredjemand kan i denne sammenhæng være en person, der har tilegnet sig det medie, der er bærer af betalingsmidlet (mobiltelefon, elektronisk kort, hacket sig ind på Internetkonto), men tredjemand kan også være en person, der er aktør i betalingsformidlingen. Det kan f.eks. være en person hos en betalingsmodtager eller systemudbyder.

\subsubsection{Misbrug begået af udefrakommende tredjemand}

Behovet for beskyttelse mod tredjemands misbrug er afhængig af, hvilket mikrobetalingssystem der er tale om. Forudbetalte elektroniske ihændehaverkort, som f.eks. telekort til telefonbokse, elektroniske "klippekort" til bus og tog m.v., som kan anvendes af enhver uden kode, er enkle, billige og simple betalingssystemer. Der er ingen risiko for tab ud over det beløb, der resterer på kortet. Sådanne betalingssystemer behøver ingen sikring mod tredjemands misbrug, forudsat, at værdien på kortet er forholdsvis begrænset. Forbrugeren må passe på kortet og ved tab lides ikke større tab end ved tab af et tilsvarende kontant pengebeløb. Hvis der kan lagres meget store beløb på kortet, bør det kunne tilknyttes en kode til beskyttelse med tredjemand.

Ved betalingssystemer, der enten er tilknyttet forbrugernes sædvanlige konto i et pengeinstitut eller hos en teleudbyder eller på anden måde giver adgang til at trække fra en konto med mulighed for at overtrække denne i et eller andet omfang, er behovet for beskyttelse mod tredjemand et helt andet.

Forbrugerens beskyttelse mod tyveri/hackning/afluring opnås med en rimelig grad af sikkerhed ved hjælp af personlige koder eller elektronisk underskrift suppleret med dels en høj grad af teknisk sikkerhed ved betalingsmidlets indretning og dels en aftalt eller lovbestemt rimelig fordeling af ansvaret og hæftelsen for misbrug. Det må her bemoerkes, at den PIN-kode, der anvendes til at åbne for en mobiltelefon, ikke kan anses for at vore betryggende sikkerhed i forhold til anvendelsen af overtakserede SMS-tjenester. Telefonens kode anvendes til at åbne for telefonen, hvorefter den ifølge sagens natur ofte vil være åben gennem længere tid (dette er en væsentlig del af formålet med at medbringe en telefon og også i teleselskabernes interesse). Såfremt en åben telefon kommer i en uberettiget tredjemands hænder, vil den uden særlig kode kunne give en ubegrænset adgang til ejerens konto, og ville på kort tid kunne bruges for et ganske stort 
beløb til f.eks. at betale mad og drikkevarer på festivals, billetter til biograf, leje af videofilm m.v.. Denne risiko kunne dog begrænses, såfremt der sættes en effektivt virkende og passende lav beløbsgrænse for, hvor meget en abonnent kan købe for pr. dag pr. telefonnummer ved hjælp af SMS/MMS'er eller hvor stort et beløb, abonnenten hæfter for som selvrisiko.

I Danmark kunne denne grænse eventuelt sættes ved $1.200 \mathrm{kr}$., som er brugerens selvrisiko ved betalingsmidler, hvor et betalingsmiddel er misbrugt af tredjemand, og den hemmelige personlige kode er anvendt.

\subsubsection{Sikkerhed mod misbrug fra betalingsformidleren eller betalingsmod- tageren}

Mikrobetalingssystemer, som blot er forudbetalte, elektroniske "klippekort", indebærer ikke nogen risiko for, at betalingsmodtager eller betalingsformidleren uretmæssigt kan gå ind på kundens konto og notere et forbrug, som kunden ikke selv har foretaget. Ved sådanne "elektroniske klippekort" er der dog risiko for, at betalingsmodtagers udstyr ikke fungerer, således at der registreres "klip", uden at kunden får tjenesteydelsen eller varen leveret. Hvis kortet rent faktisk har været anvendt i den konkrete situation, må brugeren have bevisbyrden for, at varen/tjenesteydelsen ikke blev leveret i overensstemmelse med aftalen. Derfor må brugeren have en let adgang til at reklamere straks, idet det i modsat fald vil blive næsten umuligt at løfte sin bevisbyrde. (Dette er begrundelsen for, at der må stilles krav om, at der ved det enkelte betalingssted gives oplysning om klagemulighed).

Ved Internetbaserede mikrobetalingssystemer (forud- eller bagudbetalte) findes der elektroniske "nøglesystemer", der kan sikre, at et betalingsmiddelsystem ikke kan misbruges af betalingsformidleren eller betalingsmodtageren (indholdsleverandøren). Hvis sådanne systemer anvendes, betyder det, at det vil være stort set uafviseligt for forbrugeren at betale med begrundelse $\mathrm{i}$, at forbrugeren ikke har bestilt ydelsen ${ }^{1}$.

(Der kan dog være andre problemstillinger, der gør, at kunden ikke kommer til at betale. Der har således været tilfælde, hvor forbrugerens modem uden forbrugerens vidende er blevet omkoblet til en anden server, der har foretaget opkald til sextjenester, ligesom der har været sager mod firmaer, der lader mindreårige bestille internetforbindelser, anvende sex-tjenester uden den myndige abonnents tilladelse). I Danmark og Norge er der fastlagt en praksis, hvorefter det ved opkald til sextjenester er teleselskaberne, der har bevisbyrden for, at det er abonnenten selv eller en person, han har tilladt opkaldet, der har foretaget opkaldet. Dette skyldes, at der har været en stor mængde sager, hvor kunderne har oplyst og sandsynliggjort, ikke at have ringet til disse tjenester. Teleselskaberne må derfor sikre sig, at der skaffes bevis for kundens identitet ved sådanne typer opkald.

Hvis tjenesteydelsesleverandøren indretter sit mikrobetalingssalg uden denne sikkerhed, må den erhvervsdrivende være indstillet på ikke teknisk at kunne modbevise forbrugernes indsigelse om, at det ikke er dem selv, der har bestilt ydelsen. Leverandøren af tjenesteydelsen/varen må således være indstillet på at tilbagebetale beløbet til forbrugerne.

Det er problematisk at indrette et betalingssystem med en relativt ringe sikkerhed, og såfremt systemet udbyder for ringe grad af sikkerhed, må dette anses for at være i strid med god markedsføringsskik og et problem, som tilsynsmyndighederne bør skride ind overfor, uagtet om man generelt vil acceptere en lavere grad af sikkerhed ved mikrobetalingssystemer end ved f.eks. home-bankingsystemer og betalingssystemer i øvrigt.

\footnotetext{
${ }^{1}$ Rapport Mikrobetalinger afsnit 6.2.4.
} 
Betalingssystemer skal i Danmark anmeldes til Forbrugerombudsmanden efter lov om visse betalingsmidler $\S 6$, og betalingsmidler skal i medfør af lovens generalklausul i $§ 4$ være "sikre og velfungerende".

At ovennævnte kan være et problem ses af, at VISA og MasterCard pr. 30. september 2002 har opsagt indløsningsaftalerne med en række pornosites. Årsagen er de mange klager, hvor forbrugerne nægter at have købt disse ydelser. Dette betyder, at VISA og MasterCard i praksis er nødt til at bevise, at det er kunden, der har købt ydelsen. Da det er omkostningstungt at håndtere klagerne, har man derfor valgt at opsige aftalerne med de leverandører, der repræsenterer mange forbrugerklager.

Det danske Forbrugerklagenævn har fulgt en praksis, hvorefter telefonabonnenten kun hæfter for opkald til sextjenester o. lign., som han selv har foretaget, eller som han har givet tilladelse til. Det er derfor vigtigt for udbyderne, at de sørger for kunne bevise, at det er en myndig person, der har bestilt ydelsen. Det er ligeledes afgørende, at de erhvervsdrivende sørger for at opfylde lovgivningens krav til bl.a. oplysningspligten og fortrydelsesretten, idet aftalen ellers ikke er bindende for forbrugeren.

Der er i Danmark afsagt dom i Sø og Handelsretten, hvorefter det er forbudt udbydere af sex-tjenester at udskrive regninger for bl.a. telesex ydelser alene efter en nummerviser. Den erhvervsdrivende pålægges bevisbyrden for, at der er indgået en aftale om ydelsen, hvor bestilleren har været tilstrækkeligt oplyst om ydelsens pris og andre vilkår. Dette er i overensstemmelse med almindelige aftaleretlige principper: Den, der vil kræve betaling for en ydelse, må bevise, at der er indgået aftale om den.

\subsection{Fortrolighed}

Forbrugeren har behov for, at oplysninger om den enkelte forbrugers anvendelse af mikrobetalingssystemet ikke misbruges. Forbrugernes behov for fortrolighed skal afvejes over for de erhvervsdrivendes behov for og ønske om at kunne indsamle og anvende oplysninger om kundens adfærd, kundeprofiler m.v. Disse behov må afvejes lovmæssigt med regler om indsamling, anvendelse og videregivelse af personoplysninger.

\subsection{Frivillighed}

Forbrugerne har behov for frit at kunne vælge mellem eksisterende betalingssystemer. Et sådant frit valg må også være ønskeligt fra erhvervssiden, idet dette vil styrke den nødvendige konkurrence på området.

Forbrugerne har endvidere behov for frivillighed forstået således, at det skal være muligt ved opsigelse at frigøre sig fra en én gang indgået aftale, Dvs. forbrugere skal have mulighed for at opsige aftaler om betalingssystemer uden at blive mødt af (urimelige) sanktioner fra betalingsmodtagerens eller betalingsmiddeludbyderens side.

Frivillighedskravet betyder, at aftalen om tilslutning til et mikrobetalingssystem skal udformes som en særskilt aftale. Dette gælder også, hvor et eksisterende medie (mobiltelefonen) udvikles og udbygges med et betalingssystem. Aftalen vil eventuelt kunne indgås ved fremsendelse af informationsmateriale om de nye tjenester med passende varsel om ændringerne og med anmodning om accept af den ny tjeneste. Det er ikke tilstrækkeligt med negativ aftalebinding, således at forbrugeren anses for at have accepteret aftalen, såfremt denne ikke har reageret inden en bestemt frist.

Dette synspunkt er også gjort gældende af den danske Forbrugerombudsmand i forhold til de teleselskaber, der nu udbyder ydelser betalt over overtakserede SMS'er. Her kræves efter Forbrugerombudsmandens brev af 8. august 2003 til en række teleselskaber, at der må indgås en særlig aftale med abonnenterne 
om brug af betalingstjenesterne, da der er tale om væsentligt ændrede/nye funktioner i forhold til de hidtidige abonnementsaftaler/brug af mobiltelefonerne.

\subsection{Fortrydelsesret}

Et stort antal aftaler med mikrobetalinger angår varer eller tjenesteydelser, der på grund af deres art eller karakter ligger uden for, hvad der er muligt at fortryde: En bustur kan ikke tilbageleveres, is og øl kan ikke sælges, hvis det har været leveret én gang, spil og lotterier ikke meningsfuldt tilbagesendes efter deltagelsen. Disse ydelser er omfattet af undtagelserne til fortrydelsesretten i direktivet om fjernsalg og vil ikke kunne fortrydes. Andre ydelser, som f.eks. ringetoner, vittigheder, og informationer er $\mathrm{i}$ et vist omfang omfattet af direktivets fortrydelsesret, selv om de ikke kan tilbageleveres. Her findes dog reglen om, at fortrydelsesretten ved aftale om køb af lyd- eller billedoptagelser eller EDB-programmer kun gælder, så længe forbrugeren ikke har brudt forseglingen. Sådanne ydelser kan indrettes således, at der skal brydes en elektronisk "forsegling" ved hjælp af en kode. Endvidere findes den væsentlige begrænsning i fortrydelsesretten, at forbrugeren ikke kan gøre fortrydelsesretten gældende ved tjenesteydelser, hvor udførelsen er påbegyndt med forbrugerens samtykke inden udløbet af fortrydelsesfristen.

\subsection{Sikring mod eget "uagtsomme" overforbrug}

Mikrobetalingsaftaler omhandler aftaler om småbeløb og retter sig ofte mod børn og unge, ligesom de ofte vedrører ydelser, der tilskynder til spontane køb.

Ved forudbetalte betalingssystemer uden mulighed for "optankning" over telefonen eller Internettet har disse systemer en indbygget sikring mod uagtsomt overforbrug. Sådanne systemer ses ved mobiltelefoners taletidskort, ved småpengekort og ved telefonkort til offentlige telefonbokse.

Der er dog set eksempler på, at teleudbyderen ved taletidskort ikke har standset for muligheden for at anvende telefonen, men blot trukket det merforbrugte beløb ved indsættelse af næste taletidskort. Dette må anses som værende i strid med hele idéen med taletidskort. Såfremt kunden reklamerer straks efter, at han har opdaget dette, må teleselskabet være forpligtet til at tilbageføre det beløb, der overskrider taletidskortets beløb (eller et aftalt saldomaksimum ved abonnement), medmindre kunden klart er blevet gjort opmærksom på, at der nu tales/trækkes SMS'er ud over det forudbetalte/aftalte beløb.

Ved betalingssystemer med løbende abonnement har mange forbrugere, der har overladt en mobiltelefon til et barn eller teenager, fået ubehagelige overraskelser, når de har modtaget regningen. Mikrobetalingssystemer bør derfor indrettes med mulighed for at aftale saldomaksimum.

Der har dog været dårlige erfaringer med teleselskabernes "saldomax-aftaler", hvor der har været mange tilfælde, hvor dette maksimum er overskredet, eller teleselskabet har oplyst barnet om, hvilken kode, der skulle anvendes, for at åbne for overskridelse af maksimum. Hvis ikke kunden er blevet tydeligt informeret om, at overskridelsen kunne ske, må kunden være uden forpligtelse til at betale for overskridelsen. Den indgåede aftale (som kunden har betalt særligt for), må forpligte teleudbyderen til at skulle standse leverancen, når maksimum er nået. 


\subsection{Særlige problemstillinger i relation til børn og unge}

\subsubsection{Mulighed for at spærre for køb af overtakserede SMS/MMS}

Børn og unge udgør en stor (og stigende) forbrugergruppe i relation til mobiltelefoni, overtakserede SMS'tjenester og forbrug af tjenesteydelser (og varer) købt over Internettet. Der er udstrakt enighed om, at børn og unge skal beskyttes imod udnyttelsen af deres tillid, manglende kritisk sans og manglende erfarenhed, og dette har givet sig til udtryk både i praksis ved de nordiske forbrugerombudsmænd og i ICC's kodeks.

Børn og unge bør således beskyttes mod indhold af voldelig og seksuel karakter, mod udnyttelse af deres trang til at lege og mod udnyttelse af deres mangel på økonomiske erfaringer. Dette må medføre, at børn og unge har krav på ikke at blive udsat for indholdsydelser, der virker krænkende $\mathrm{i}$ form af seksuelle eller voldelige fremstillinger $\mathrm{i}$ ord, tegn eller billeder, ligesom der må opstilles en beskyttelse mod at sætte store pengesummer over styr i spil og konkurrencer og lign.

Mindreårige er i et vist omfang beskyttet mod at påtage sig økonomiske forpligtelser, der ikke er til gavn for deres behov, medens der ikke findes nogen beskyttelse mod at komme til at se eller læse pornografiske eller voldelige fremstillinger eller nogen grænser for, hvilke spil og konkurrencer, der kan deltages i. Der må derfor anses at vare et stort behov fra forbrugerside for, at der kan valges en eller anden form for sparring for $k ø b$ af indholdsydelser, således at visse typer ydelser generelt kan fravaelges/spcerres for. En sådan spærring kendes i dag for bestemte telefonnumre, der bl.a. indeholder sextjenester m.v. Såfremt det ikke er muligt at opbygge systemer, der kan sondre mellem indholdsydelserne, må en mulig løsning være, at der udbydes mulighed for at fravælge selve funktionen med de overtakserede SMS/MMS.

\subsubsection{Hvem hæfter for den mindreåriges forbrug?}

Udgangspunktet er, at mindreårige ikke selv kan indgå aftale, der indebærer gældsstiftelse og dermed ikke kan indgå aftale om et telefonabonnement, men skal have værgens samtykke hertil. Endvidere kan end ikke værgen indgå en for den umyndige forpligtende aftale om, at den umyndige ubegrænset kan hæfte for køb af varer og tjenesteydelser via overtakserede SMS'er eller på anden måde, hvorpå den umyndige overlades mulighed for løbende at købe på kredit.

En mindreårig kan dog uden værgens tilladelse oprette en forudbetalt konto, købe taletidskort og lignende, hvis kontoen alene betales af midler, som den mindreårige har fri rådighed over, men det påhviler kontoudsteder at sikre sig, at der er tale om midler, som den mindreårige kan råde over. Kontoen må derfor som minimum ikke give mulighed for overtræk.

Da udlevering af elektroniske betalingsmidler med tilknyttet kort giver mulighed for overtræk, bør sådanne betalingsmidler som hovedregel ikke udleveres til unge under 18 år. Ved overtræk vil den gældsstiftelse, der sker ved overtrækket være ugyldig, medmindre myndighederne (i Danmark Statsamtet) har givet sin godkendelse. Den unge skal kun betale for overtrækket efter nyttereglen. 
Den mindreårige kan således ikke hæfte for, at overtrækket på et kontokort, kreditkort, mikrochipkort eller andet, der giver mulighed for at købe varer eller tjenesteydelser ud over et ganske snævert afgrænset brug.

Ud over reglerne om mindreåriges ret til at disponere over selverhvervede midler må den mindreårige efter omstændighederne med værgens samtykke kunne anses for at kunne hæfte for et telefonabonnement uden særlige tjenester og uden mulighed for at købe via overtakserede SMS'er, ligesom en mindreårig må kunne hæfte for brugen af et elektronisk kort, der registrerer løbende forbrug af f.eks. buskørsel til betaling over en løbende konto. En mindreårig kan dog ikke alene indgå aftale om sådanne kort, hvis de giver adgang til at købe andet end den basale ydelse. Et togkort med elektronisk registrering er således inden for det, en værge kan give samtykke til, at den umyndige selv skal hæfte for, medens et togkort, der yderligere giver adgang til køb af forlystelser, souvenirs og/eller mad og drikkevarer, ligger uden for værgens kompetence til at forpligte den mindreårige på samme måde, som en værge ikke med bindende virkning for den mindreårige kan give samtykke til at indgå aftale om erhvervelse af kreditkort, Dankort m.v. med den virkning, at den umyndige hæfter for overtræk eller tredjemands misbrug.

Om værgen hæfter i medfør af, at han har skrevet under som værge, er tvivlsomt ud fra almindelige kautionsretlige overvejelser, hvorefter kautionisten ikke hæfter, såfremt den, der kautioneres for, ikke gør det selv. Værgens hæftelse kunne herefter tænkes i form af et erstatningsansvar, men dette forudsætter et ansvarsgrundlag og dermed, at værgen har foretaget sig noget, han kan bebrejdes.

Hvis den mindreårige eller værgen har skrevet under på en kontrakt, som de ikke har kompetence til, idet der er tale om ufravigelige lovregler til beskyttelse af den mindreårige, er aftalen ugyldig, og den mindreårige hæfter ikke for det forbrug, der sker i medfor af aftalen ud over, hvad der må anses for at være kommet ham til nytte. Denne nytteværdi vil ofte anses for at være lav, idet de fleste telefonsamtaler og overtakserede SMS/MMS'er må betegnes som ikke-nødvendige set i denne sammenhæng.

En undersøgelse blandt danske skoleelever i 6. og 9. klasse (hvor mere end $90 \%$ af eleverne havde en mobiltelefon) antyder, at ca. hver 7. af disse mindreårige mobiltelefonbrugere selv havde indgået på kontrakter om mobiltelefoner. En del af disse er dog med taletidskort, der kan købes kontant for midler, som den mindreårige lovligt kan råde over.

De ovenforstående overvejelser om den mindreåriges hæftelse er dog i et vist omfang rent teoretiske, da teleudbyderne ofte sørger for at få værgens underskrift på telefonkontrakten. Værgen underskriver sig som kontraktsansvarlig, hvilket betyder, at den mindreårige ikke selv hæfter over for teleudbyderen, men at værgen hæfter umiddelbart.

Spørgsmålet er herefter, om den myndige kontraktsansvarlige hæfter for enhver brug, som den mindreårige, der får overladt en mobiltelefon eller andet betalingsmedie, foretager, uanset om dette ligger uden for aftalens "kerneområde" - dvs. er mere og andet end telefonsamtaler og meddelelses-SMS'er. Svaret på dette spørgsmål må bero på, hvilken aftale der er indgået mellem den, der underskrev aftalen, og udbyderen af teleydelsen/betalingsmidlet. Hvis aftalen f.eks. oprindelig var en aftale om, at der kan foretages telefonsamtaler og sendes SMS'er over abonnementet, må det anses at ligge uden for denne aftale, at der kan foretages køb af varer og tjenesteydelser via overtakserede SMS'er. For at brugeren af telefonen (den mindreårige) kan foretage sådanne overtakserede SMS/MMS-køb med abonnentens hæftelse til følge, må teleudbyderen derfor indgå en særskilt aftale med abonnenten herom. Hvis ikke der findes en sådan særskilt aftale, der indbefatter brugen af overtakserede SMS/MMS'er, er teleudbyderens udvidelse af abonnementet et forhold, der falder uden for det, der er aftalt med forbrugeren, hvilket 
vil være uforbindende for forbrugeren i overensstemmelse med almindelige formueretlige principper og formuleret i de forbrugerbeskyttende regler herom (i Danmark Forbrugeraftalelovens $\S 4$ ).

\subsection{Sammenfatning}

De særlige, retlige problemer - som samtidig udgør nogle af barriererne for udvikling og anvendelse af nye betalingsformer - kan herefter stilles op således:

1. Brugeren af mikrobetalingssystemer har behov for frivillige, fortrolige, sikre og gennemsigtige betalingssystemer, der er sikret mod tredjemands misbrug, og som indeholder oplysninger om aftalevilkår, kontobevægelser m.v.

2. Den gældende lovgivning, som bl.a. er baseret på EU-direktiver, opstiller en række krav om oplysninger, der skal gives brugeren af et betalingssystem, og køberen af varer og tjenesteydelser ved fjernsalg. Disse kravs opfyldelse i fuldt omfang vanskeliggør og fordyrer anvendelsen af betalingssystemer. Disse udgifters vægt bliver forholdsvist store ved små transaktioner og hæmmer muligheden for at udvikle betalingssystemer og handel vedrørende mange, små ydelser.

3. Brugerens retlige behov ved indgåelse af aftale om mikrobetalingssystemer vedrører oplysninger om systemets anvendelse og udbredelse, mulighed for opsigelse/fortrydelse af tilslutning til mikrobetalingssystemet, hvis dette er baseret på abonnementsordning og oplysning om refusion af eventuel resttilgodehavende ved forudbetalte systemer. Brugeren har endvidere behov for at vide, hvem der udbyder betalingssystemet, og hvor der kan klages ved uregelmæssigheder i systemet. Brugeren har endvidere ved kontobaserede systemer behov for en oversigt over det løbende forbrug, med mulighed for kontrol gennem oplysning om, hvornår og til hvem den enkelte betaling er sket.

4. Brugeren har behov for beskyttelse mod tredjemands uberettigede brug og mod fejlkonteringer forårsaget af systemfejl.

5. Brugeren har behov for at kunne aftale beløbsbegrænsninger på bestemte funktioner og/eller på hele kontoen (saldomaksimum).

6. Brugeren har behov for beskyttelse af persondata og mulighed for at få oplysning om, hvilke data, der opbevares, og hvad disse data anvendes til.

7. Særligt i relation til børn og unge er der behov for beskyttelse mod indholdet af de udbudte ydelser (spil, konkurrencer, vold, sex), og der er her særligt behov for en reel mulighed for at styre/begrænse forbruget.

Opstillingen af de erhvervsdrivende og forbrugernes behov viser, at disse i nogen grad er modsatrettede: De erhvervsdrivende har brug for billige, enkle systemer, og forbrugeren har brug for gennemsigtighed, oplysninger og sikkerhed. Ved en lidt dyberegående analyse er denne modsætning mellem parternes interesser nok mindre, da de erhvervsdrivende har brug for tilfredse kunder, der tør bruge systemerne (i hvert fald de mere lødige, som ønsker at kunne fungere i længere tid på markedet). Herudover har de erhvervsdrivende også brug for sikre systemer og gennemsigtighed for så vidt angår deres mulighed for at kunne dokumentere egne krav over for kunderne og over for andre erhvervsdrivende. På den anden side er kunderne næppe interesserede $\mathrm{i}$ at blive overbe- 
byrdet med oplysninger, hver gang man har handlet for 5 kr. Forbrugerne er også interesserede i, at der udvikles enkle, billige og funktionelle betalingssystemer. Det er dette udgangspunkt, der skal danne fundamentet for den retlige regulering, som skal beskytte forbrugerne uden at hæmme udviklingen unødigt. 


\section{Relevant EU-regulering}

\subsection{Oversigt}

I dette kapitel gennemgås de relevante EU-direktiver. Disse direktiver udgør "mindstemålet" for den retlige regulering, hvilket betyder, at det enkelte land ikke kan indføre regler, der strider mod kravene i denne fællesskabsretlige regulering. Uanset om de nordiske lande måtte ønske at sænke forbrugerbeskyttelsesniveauet på visse områder for så vidt angår mikrobetalinger under henvisning til, at det skal være muligt at gennemføre små betalinger på en enkel og billig måde, vil dette ikke være muligt, såfremt det ville stride mod direktivbestemmelser.

De for mikrobetalinger relevante direktiver er: Direktiv om vildledende og sammenlignende reklame, direktiv om forbrugerbeskyttelse i forbindelse med aftaler indgået uden for fast forretningssted, direktiv om forbrugerbeskyttelse i forbindelse med aftaler vedrørende fjernsalg, direktiv om E-handel, direktiv om urimelige kontraktvilkår i forbrugeraftaler og direktiv om forbrugerkredit.

Direktiv om forbrugerbeskyttelse i forbindelse med angivelse af priser på forbrugsvarer findes ikke specielt relevant på mikrobetalinger, idet dette direktivs anvendelsesområde er fastsættelse af krav om angivelse af salgspriser pr. måleenhed for varer, der udbydes af forhandlere til forbrugerne.

\subsection{Direktiv om vildledende og sammenlignende reklame $(84 / 450$ som ændret ved EP/R Dir 97/55)}

\subsubsection{Direktivets indhold}

Formålet med dette direktiv er bl.a. at beskytte forbrugerne, erhvervsdrivende og offentligheden i almindelighed med vildledende reklamer og urimelige følger heraf.

Ved reklame forstås i medfør af artikel 2, litra 1, enhver form for tilkendegivelse i forbindelse med udøvelse af virksomhed som handlende, håndværker eller industridrivende eller udøvelsen af liberalt erhverv, som har til formål at fremme afsætningen af varer eller tjenesteydelser.

Vildledende reklame defineres i artikel 2, litra 2, som enhver reklame, som på nogen måde, herunder dens udformning, skaber eller er egnet til at skabe et urigtigt indtryk hos de personer, den er rettet til eller når ud til, og som på grund af sin vildledende karakter kan antages at påvirke deres økonomiske adfærd, eller som af disse grunde skader eller er egnet til at skade en konkurrent.

Ved afgørelsen af, hvorvidt en reklame er vildledende, skal der i medfør af direktivets artikel 3 tages hensyn til alle dens bestanddele og især til oplysninger vedrørende:

a) egenskaber ved varerne eller tjenesteydelserne, såsom det omfang i hvilket de står til rådighed, deres beskaffenhed, udførelse og sammensætning, måde og tidspunktet for 
deres fremstilling eller ydelse, deres hensigtsmæssighed, anvendelsesmuligheder, mængde, specifikationer, geografiske eller handelsmæssige oprindelse eller de resultater, som kan forventes opnået ved brugen, eller resultaterne af og de vigtigste karakteristika ved afprøvning eller kontrol af varerne eller tjenesteydelserne;

b) prisen eller den måde, hvorpå prisen beregnes, samt betingelserne for levering af varerne og erlæggelse af tjenesteydelserne;

c) annoncørens status, egenskaber og rettigheder, såsom hans identitet og formue, hans kvalifikationer og immaterielle rettigheder eller de af ham tilkendte prisbelønninger og udmærkelser.

Medlemsstaterne skal i henhold til artikel 4 påse, at der i forbrugernes, konkurrenternes og offentlighedens interesser findes tilstrækkelige og effektive midler til bekæmpelse af vildledende reklame.

Disse midler skal omfatte retsforskrifter, hvorefter personer eller organisationer, der i henhold til medlemsstaternes lovgivning har en legitim interesse $i$ at få vildledende reklame forbudt, får adgang til enten at indlevere en sag for retten i anledning af sådan reklame, og/eller at indbringe sådan reklame for en administrativ myndighed, som har kompetencen til enten at træffe afgørelsen om klager eller at indlede passende retsforfølgning.

Direktivet er for så vidt angår vildledende reklame et minimumsdirektiv.

\subsubsection{Direktivet set i forhold til mikrobetalinger}

Direktivets formuleringer vedrørende vildledende reklamer er så åbne og brede, at der ikke her kan siges at ligge nogen konkret grænse for en retlig regulering af mikrobetaling, men direktivet medfører, at der fra forbrugerside må kunne stilles krav om, at myndighederne skrider ind over for vildledende reklamer vedrørende varer eller tjenesteydelser, der betales ved hjælp af mikrobetalingssystemer.

\subsection{Direktiv om forbrugerbeskyttelse i forbindelse med aftaler ind- gået uden for fast forretningssted (R dir 85/577/EØF)}

\subsubsection{Direktivets indhold}

Direktiv om forbrugerbeskyttelse $\mathrm{i}$ forbindelse med aftaler indgået uden for fast forretningssted gælder for aftaler indgået mellem en forbruger og en erhvervsdrivende under en udflugt arrangeret af den erhvervsdrivende uden for dennes faste forretningssted eller i forbindelse med den erhvervsdrivendes besøg hos forbrugerens eller på forbrugerens arbejdsplads. Dette gælder dog kun, hvis besøget ikke sker efter udtrykkelig anmodning fra forbrugeren.

Direktivet giver forbrugeren fortrydelsesret vedrørende varer og tjenesteydelser samt en pligt for den erhvervsdrivende til skriftligt at oplyse forbrugeren herom.

\subsubsection{Direktivet set i forhold til mikrobetalinger}

Direktivet om aftaler indgået uden for fast forretningssted vil kun have forholdsvis ringe betydning i mikrobetalingsforhold, idet en stor del af sådanne aftaler indgås i forbindelse med fjernhandel, og direktiv om aftaler indgået uden for fast forretningssted gælder 
for aftaler indgået af en forbruger og en erhvervsdrivende, der er til stede fysisk på f.eks. en udflugt, på forbrugerens arbejdsplads eller hjemme hos forbrugeren.

Såfremt en erhvervsdrivende arrangerer udflugter med henblik på at sælge varer eller tjenesteydelser til forbrugeren, hvor der betales med mikrobetalingsmidler, f.eks. et småpengekort eller et til sådant brug særligt udviklet mikrochipkort, ville sådanne forhold dog være omfattet af direktivet. Dette medfører, at forbrugeren har fortrydelsesret $\mathrm{i}$ medfør af artikel 5, og at den erhvervsdrivende skal oplyse herom, jf. artikel 4.

Da mikrobetalinger angår køb af ganske små varer eller tjenesteydelser, vil dette dog oftest angå mad og drikkevarer eller tjenesteydelser (forpligtelser af enhver art), som ikke kan tilbageleveres og dermed ikke fortrydes.

Direktivets anvendelsesområde ved mikrobetalinger vil dermed kun omfatte en meget lille del af den mikrobetalingssituation, der er omfattet af denne undersøgelse.

Hvis der skulle udvikle sig et mikrobetalingsmarked af en art, som er omfattet af dette direktiv, og som forbrugeren og erhvervsdrivende er interesseret $i$, indeholder direktivet i artikel 3, stk. 1, en bestemmelse om, at medlemsstaterne kan vedtage, at dette direktiv kun skal gælde for aftaler, ifølge hvilken den modydelse, der skal erlægges af forbrugeren overstiger et bestemt beløb. Dette beløb må ikke overstige 60 ECU. Denne undtagelse kunne sættes i anvendelse for sådanne særlige situationer.

\subsection{Direktiv om forbrugerbeskyttelse i forbindelse med aftaler ved- rørende fjernsalg (EP/R Dir 97/7/EF)}

\subsubsection{Direktivets indhold}

Direktiv om fjernsalg vedrører aftaler mellem en leverandør og en forbruger vedrørende varer eller tjenesteydelser, der er indgået som led i et system for varesalg eller levering af tjenesteydelser organiseret af leverandøren, som for den pågældende aftales vedkommende udelukkende anvender en eller flere former for fjernkommunikationsteknik frem til og inklusiv selve indgåelsen af aftalen, jf. artikel 1.

Ved fjernkommunikationsteknik forstås f.eks. telefon, teleshopping, Internet, brev og SMS/MMS'er. Vareautomater og automatiserede forretningslokaler samt anvendelse af offentlige telefonbokse er undtaget fra direktivet, jf. artikel 3, ligesom artikel 4, 5 og 6 samt 7, stk. 1, ikke finder anvendelse på aftaler om levering af tjenesteydelser i form af logi, transport og forplejning og fritidstilbud, når leverandøren ved aftalens indgåelse påtager sig at levere sådanne ydelser på en forud fastlagt dato eller i et nærmere bestemt tidsrum. I tilfælde af udendørsbegivenheder, kan leverandøren undtagelsesvist forbeholde sig ret til ikke at anvende artikel 7, stk. 2, under særlige omstændigheder.

Når en aftale er omfattet af direktivet, skal forbrugeren $i$ god tid inden aftalens indgåelse have en lang række oplysninger i medfør af artikel 4. Disse oplysninger er:

a) leverandørens navn og, i tilfælde af aftaler hvor der kræves forudbetaling, tillige hans adresse

b) varens eller tjenesteydelsens vigtigste egenskaber

c) varens eller tjenesteydelsens pris inkl. alle afgifter

d) eventuelle leveringsomkostninger

e) betalings- eller leveringsbetingelser eller betingelserne for opfyldelse af aftalen 
f) eventuel fortrydelsesret, undtagen i de i artikel 6, stk. 3, nævnte tilfælde

g) omkostningerne ved anvendelse af fjernkommunikationsteknikken, når de beregnes efter anden tarif end grundtariffen

h) det tidsrum, i hvilket tilbuddet eller prisen er gyldig

i) i givet fald aftalens korteste gyldighedsperiode i forbindelse med aftaler om varige eller regelmæssige vareleverancer eller tjenesteydelser.

Oplysningerne skal gives på en klar og forståelig måde "under anvendelse af midler, der er tilpasset den anvendte fjernkommunikationsteknik", jf. artikel 4, stk. 2. Der stilles således ikke krav om skriftlighed i direktivet, men kun om, at oplysningerne ud over at være formuleret klart og forståeligt skal/må være tilpasset det medie, der anvendes til aftalens indgåelse. I direktivets betragtninger (nr. 11) hedder det, at anvendelsen af fjernkommunikationsteknikker ikke bør medføre en begrcensning af den information, der gives forbrugeren. Forbrugeren skal i medfør af artikel 5 modtage bekræftelse skriftligt eller på et andet varigt medium, som er til hans rådighed og tilgængeligt for ham. Direktivet fastlægger ikke i teksten, hvad der kan anses som "varigt medium", men ud fra formålet med bestemmelsen, må der lægges vægt på, om det er muligt for forbrugeren at opbevare (lagre) de oplysninger, han modtager direkte med det pågældende medium på en sådan måde, at oplysningerne $\mathrm{i}$ en rimelig periode er tilgængelig for fremtidig reference (kontrol og bevis) og kan reproduceres. Bekræftelsen skal omfatte oplysningerne i litra a-f. Der skal under alle omstændigheder forelægges skriftlig oplysning om betingelser og de nærmere regler for udøvelsen af fortrydelsesretten, om den fysiske adresse på leverandørens forretningssted, hvortil forbrugeren kan indgive eventuelle klager, oplysninger om foreliggende eftersalgsservice og garantibetingelser og om betingelserne for ophævelse af aftalen, hvis denne er af ubestemt varighed eller af mere end ét års varighed.

Dette krav om oplysninger gælder dog ifølge artikel 5, stk. 2, ikke ved tjenesteydelser, hvor selve opfyldelsen sker ved anvendelse af fjernkommunikationsteknik, når disse tjenesteydelser leveres samlet på én gang, og hvor faktureringen foretages af formidleren af fjernkommunikationsteknikken. Rækkevidden af denne undtagelse er uklar, men de eksempler, der er givet ved udarbejdelsen af bestemmelsen (oplysningstjenester) peger på en meget snæver anvendelse af denne undtagelse. Det har formentlig alene været tanken at undtage de situationer, hvor det ikke er muligt at indskyde et ekstra led indeholdende en ordrebekræftelse med de relevante oplysninger, førend leveringen af selve ydelsen. Sprogligt kan bestemmelsen anses at angå anvendelsen af fjernkommunikationsteknik til levering af f.eks. oplysninger, hvor man på én gang anvender telefonsystemet og får sin tjenesteydelse leveret. Ringetoner, vittigheder, horoskoper m.v. bliver ikke på samme måde "leveret samlet på én gang", da der er flere kommunikationsgange mellem forbruger og indholdsleverandør, hvilket giver mulighed for, at der fysisk kan afsendes en ordrebekræftelse, og disse indholdsydelser kan derfor næppe anses for omfattet af undtagelserne i artikel 5, stk. 2.

Ved aftaler indgået via fjernhandel har forbrugeren ifølge direktivets artikel 6 fortrydelsesret med en frist på mindst 7 hverdage løbende fra modtagelsen af varer eller for tjenesteydelsers vedkommende fra aftalens indgåelse eller fra den dato, hvor den pligtiges oplysninger om fortrydelsesret er givet, dog maksimum 3 måneder.

Forbrugeren kan ikke på forhånd give afkald på fortrydelsesretten, men artikel 6, stk. 3, indeholder nogle situationer, hvor fortrydelsesretten ikke kan gøres gældende. De for mikroaftaler mest relevante undtagelser er: 
1) tjenesteydelser, hvor udførelsen er påbegyndt med forbrugerens samtykke inden fortrydelsesfristens udløb,

2) varer, som er fremstillet efter forbrugerens specifikationer eller har făet et tydeligt personligt præg eller som på grund af deres beskaffenhed ikke kan tilbagesendes eller må antages at ville blive forringet eller forældet hurtigt,

3) levering af lyd- eller billedoptagelser eller edb-programmer, som forbrugeren har brudt plomberingen på,

4) levering af aviser, tidsskrifter og magasiner,

5) tips- og lotteriydelser.

Rækkevidden af disse undtagelser er ikke ganske klar. Således er det usikkert, hvad der forstås ved varer, som på grund af deres beskaffenhed ikke kan tilbagesendes. Foreløbig angår de fleste mikroaftaler over fjernsalg dog ydelser, der bedst kan analogiseres med tjenesteydelser, hvorfor bestemmelsen næppe får stor betydning, i denne sammenhæng.

Derimod vil reglen i artikel 6, stk. 3, "tjenesteydelse, hvor udførelsen er påbegyndt med forbrugerens samtykke", kunne finde umiddelbar anvendelse. Denne regel medfører, at levering af f.eks. ringetoner, horoskoper og lign. kan indrettes således, at indholdsleverandøren, efter at forbrugerens bestilling af en indholdsydelse er modtaget, kan sende forbrugeren en besked om, at bestilling er modtaget, og at levering kan ske, så snart forbrugeren har bekræftet at give afkald på sin fortrydelsesret. Dette afkald kan gives ved at sende en besked med "ja, tak, begynd levering nu". Forbrugeren kan ikke på forhånd, dvs. inden aftalens indgåelse ved forbrugerens afsendelse af sin bestilling, give afkald på sin fortrydelsesret. Fortrydelsesretten er præceptiv, og forbrugeren skal have "den i stk. 1 fastsatte fortrydelsesret" for at kunne give samtykke til påbegyndelsen af leverancen inden fristens udløb.

Medmindre andet er aftalt, skal leverandøren effektuere bestillingen senest 30 dage regnet fra dagen efter, at forbrugeren har afgivet sin bestilling, jf. artikel 7.

Artikel 8 bestemmer, at medlemsstaterne skal sørge for at fastsætte passende regler om, at en forbruger kan anmode om annullering af betaling, hvis et betalingskort er blevet anvendt svigagtigt $\mathrm{i}$ forbindelse med en aftale om fjernsalg, som omfattes af direktivet, og at forbrugeren i tilfælde af svigagtig anvendelse får krediteret eller refunderet de foretagne indbetalinger. Reglen om, at forbrugeren ikke er bundet af levering i tilfælde af, at dette sker uden forudgående anmodning, findes i artikel 9, der lyder:

"Medlemsstaterne træffer de nødvendige foranstaltninger til at

- forbyde levering af varer eller tjenesteydelser til en forbruger uden forudgående bestilling fra denne, hvis leverancen indeholder en anmodning om betaling

- fritage forbrugeren for enhver modydelse i tilfælde af levering uden forudgående anmodning, da manglende svar ikke er ensbetydende med samtykke."

Endelig findes i artikel 10 en bestemmelse om, at en leverandørs anvendelse af telefax eller telefonisk opkaldsautomat kræver forudgående samtykke fra forbrugeren, samt at andre fjernkommunikationsteknikker end disse, som tillader individuel kommunikation, kun kan anvendes, hvis forbrugeren ikke klart modsætter sig det. Dette omfatter også udsendelse af SMS'er med reklamemateriale.

Direktivet, der er et minimumsdirektiv, fastsætter, at forbrugeren ikke kan give afkald på sin beskyttelse i henhold til direktivet. 


\subsubsection{Direktivet set i forhold til mikrobetalinger}

Direktivet om forbrugerbeskyttelse i forbindelse med fjernsalg vil utvivlsomt omfatte en stor del af de aftaler, der omhandles i denne rapport, idet disse ofte vil være indgået via fjernkommunikationsteknik som led i et af leverandøren udbudt "system for varesalg eller levering af tjenesteydelser".

Dette betyder dels, at der inden aftalens indgåelse - dvs. inden forbrugerens bestilling skal gives oplysninger i henhold til artikel 4, og efter aftalens indgåelse skal have bekræftelse på aftalen skriftligt på papir eller på andet varigt medie, som er til hans rådighed og tilgængeligt for ham, jf. artikel 5, dels at der er som udgangspunkt fortrydelsesret.

I relation til mikrobetalinger er det derfor væsentligt at definere, på hvilke måder, der kan gives forbrugeren den efterfølgende (skriftlige) bekræftelse, og hvad der skal forstås som "varigt medium, som er til hans rådighed og tilgængeligt for ham". Hvis leverandøren sikrer sig (ved at spørge om forbrugerens e-mailadresse), at forbrugeren har adgang til Internettet, må oplysningerne sendt som e-mail opfylde kravet i artikel 5, da disse kan gemmes eller printes ud af forbrugeren selv, medens det næppe er tilstrækkeligt, at oplysningerne alene gives på leverandørens hjemmeside med en generel henvisning til, at den findes her. Hvis dette skal opfylde kravet i artikel 5 om varigt medium, som er til forbrugerens rådighed og tilgængeligt for ham, kræver dette, dels at oplysningerne bliver på leverandørens hjemmeside (eller en hertil særligt indrettet internetside) i ganske lang tid (i hvert fald indtil forbrugeren har modtaget en kontoudskrift med oplysningerne), at leverandøren ikke selv kan ændre oplysningerne og at der er oplyst om hjemmesideadresse via SMS/MMS eller e-mail. Om dette er nok, er dog tvivlsomt, idet der stadig er store dele af befolkningen, der ikke har jævnlig adgang til Internettet, og det synes kunstigt at stille forbrugeren i en situation, hvor han skal på biblioteket for at læse, hvilken vare til hvilken pris han har købt, om der er leveringsbetingelser, hvilke betalingsbetingelser, der gælder, samt om han har fortrydelsesret. Særligt vedrørende fortrydelsesretten må det gælde, at anvendelsen heraf forudsætter kendskab til den.

Det kan også diskuteres, om forbrugeren i henhold til direktivets krav har "modtaget" en ordrebekræftelse/kvittering og dermed også oplysningerne, hvis den blot findes på leverandørens hjemmeside. Det må derfor formentlig kræves, at forbrugeren ved aftaler indgået over telefonen som minimum får en SMS/MMS eller en e-mail med henvisning til en sådan internetside for at opfylde kravene i artikel 5. Dette forudsætter dog, at forbrugeren overfor den erhvervsdrivende har oplyst at have adgang til Internettet.

Direktivet indeholder en række undtagelser fra fortrydelsesretten. Dette gælder bl.a. varer, som er fremstillet efter forbrugerens specifikationer eller har fået et tydeligt personligt præg. Dette er næppe nogen stor del af mikrobetalingerne, men hvis der skulle være tilfælde, hvor forbrugeren via fjernsalg inden for de små beløb, mikrobetalinger omhandler, har fremstillet varer efter særlige specifikationer eller med personligt præg, er disse varer altså omfattet. Som eksempel kan nævnes udfærdigelsen af individuelle badges eller klistermærker el.lign. Her ville der ikke være fortrydelsesret.

Undtagelsen om varer, som ikke kan tilbagesendes eller må antages at ville blive forringet eller forældet hurtigt, omfatter bl.a. salg af mad og drikkevarer bestilt over et elektronisk fjernkommunikationsmedie (f.eks. mobiltelefon, hvor der kan bestilles øl og andre drikkevarer til levering i en nærliggende bar). 
Ved tjenesteydelser, hvor udførelsen er påbegyndt ved forbrugerens samtykke inden fortrydelsesfristens udløb, er det vanskeligste led at afgrænse, hvornår forbrugerens samtykke kan siges at foreligge. I almindelig aftaleret antages et samtykke at kunne være andet end et klart udtalt verbalt samtykke. Det kan også ligge underforstået i de handlinger, den der accepterer, foretager sig eller på anden måde underforstået i situationen.

Det, der er afgørende i relation til samtykket, er dog, hvad forbrugeren skal give samtykke til. Efter direktivets tekst og indhold skal forbrugeren give samtykke til, at udførelsen af tjenesteydelsen påbegyndes inden udløbet af fortrydelsesretten. Fortrydelsesfristen må ifølge direktivets ordlyd og formål skulle være påbegyndt, dvs. at aftalen skal være indgået med oplysning om fortrydelsesrettens eksistens, førend forbrugeren kan give samtykke til, at den afkortes. Dvs. at hvis forbrugeren er oplyst om, at der er en fortrydelsesret ved fjernkøb af sådanne tjenesteydelser, kan systemet lovligt indrettes sådan, at forbrugeren oplyses om, at hvis han fortsætter processen med aftalens gennemførelse (f.eks. ikke afbryder telefonen inden for de næste 5 sekunder, eller hvis han trykker på en "accept-knap"), er dette ensbetydende med, at der ikke på et senere tidspunkt kan fortrydes. Det afgørende er ikke, hvorledes samtykket til afbrydelse af fortrydelsesfristen gives, men at den gives, og at forbrugeren er oplyst om, at han giver samtykke til, at levering påbegyndes nu.

Ved levering af lyd-eller billedoptagelser eller edb-programmer afbrydes fortrydelsesretten, når forbrugeren bryder plomberingen herpå. Dette må også omfatte den situation, at forbrugeren (som ved ordrebekræftelsen har fået oplyst, at han har fortrydelsesret) oplyses om, at når der trykkes på OK-knappen på mobiltelefonen, "godkend" på computerens skærmbillede, indtastes en kode eller lign., åbnes adgangen til det bestilte, og herefter kan der ikke fortrydes. Denne undtagelse vil gælde ringetoner, spil, vitser, horoskoper m.v.

Fastlæggelse af undtagelsen vedrørende tips- og lotteriydelser må ske konkret under vurdering af, hvor stor en del af ydelsen, der består af elementerne tips- eller lotteriydelser.

Hvis forbrugeren benytter sin fortrydelsesret, skal leverandøren vederlagsfrit tilbagebetale de beløb, som forbrugeren har betalt, jf. artikel 6, stk. 2, og de eneste omkostninger, forbrugeren kan pålægges, er de direkte udgifter i forbindelse med tilbagelevering af varen. Tilbagebetaling skal ske snarest og senest inden 30 dage.

\subsection{Direktiv om visse retlige aspekter af informationssamfundstje- nester, navnlig elektronisk handel, i det indre marked (Direktivet om elektronisk handel) EU Dir 2000/31}

\subsubsection{Direktivets indhold}

Direktivet om elektronisk handel regulerer en række aspekter ved elektronisk handel, som også kan have betydning for mikrobetalinger.

Direktivet finder ikke anvendelse på spil, som indebærer, at der gøres en indsats med penge i hasardspil, herunder lotteri og væddemål.

Af væsentligst interesse for mikrobetalinger findes reglerne i artikel 5 om krav vedrørende let, umiddelbar og vedvarende adgang for tjenestemodtageren og de kompetente 
myndigheder til en række oplysninger bl.a. vedrørende tjenesteyderens navn, fysiske adresse, e-mailadresse m.m., artikel 6 med kravet om, at kommerciel kommunikation klart skal kunne identificeres som sådan, at reklametilbud som f.eks. rabatter, præmier og tilgift samt konkurrencer og spil klart skal kunne identificeres som sådanne, og at betingelserne for at opnå rabat m.v. eller deltage i spil og konkurrencer skal oplyses.

Endvidere indeholder direktivet i artikel $7 \mathrm{krav}$ om, at uopfordret kommerciel elektronisk post klart og utvetydigt er angivet som sådan, når modtageren modtager den, samt at der skal etableres "opt-out" registre for personer, der ikke ønsker sådan kommerciel kommunikation.

Direktivet indeholder i artikel 9-11 regler om, dels at det skal være muligt at indgå juridisk bindende kontrakter elektronisk, dels en række krav om oplysninger, der skal gives, inden ordre afgives, samt at der skal gives ordrebekræftelse uden unødig forsinkelse og elektronisk. Disse oplysninger skal gives ud over de oplysninger, der er omfattet af direktivets artikel 5 om den generelle oplysningspligt.

Artiklerne 12-15 indeholder regler for formidleransvar for tjenesteyderen, der medfører, at den tjenesteyder, der leverer en informationssamfundstjeneste (f.eks. et teleselskab) ved ren videreformidling, ikke er ansvarlig for den transmitterede information, såfremt han ikke selv har iværksat transmissionen, udvalgt modtageren af denne og ikke udvælger og ikke ændrer den transmitterede information. Tjenesteyderen kan dog af en domstol eller en administrativ myndighed pålægges at bringe en overtrædelse af gældende regler til ophør eller forhindre den. Ligeledes er tjenesteyderen under visse i artikel 13 nævnte betingelser ikke ansvarlig for transmission af information, men tjenesteyderen er forpligtet til efter krav fra domstole og administrative myndigheder at bringe en overtrædelse til ophør eller hindre den, endelig bestemmes i artikel 14, at tjenesteyderen ikke pådrager sig ansvar for information oplagret på anmodning af en tjenestemodtager forudsat, at tjenesteyderen ikke har konkret kendskab til den ulovlige aktivitet eller information, og at tjenesteyderen fra det øjeblik, hvor han får et sådant kendskab, straks tager skridt til at fjerne informationen eller hindre adgang til den.

Hvis tjenestemodtageren handler under tjenesteyderens myndighed eller kontrol, er tjenesteyderen ikke fritaget for ansvar for tjenestemodtagerens handlinger.

Tjenesteyderen må ikke pålægges en generel pligt til overvågning af den information, de fremsender eller oplagrer, eller en generel forpligtelse til aktivt at undersøge forhold eller omstændigheder, der tyder på ulovlig virksomhed.

\subsubsection{Direktivet set i forhold til mikrobetalinger}

Direktivet om e-handel er stort set $\mathrm{i}$ sin helhed af væsentlig betydning i mikrobetalinger og vil blive inddraget under gennemgangen af den nationale ret.. Særligt kan nævnes reglerne om oplysningspligt og ordrebekræftelse, om identifikation af kommerciel kommunikation, og at eventuelle vilkår for at opnå rabat, tilgift og præmier (i det omfang dette er lovligt i relation til national lovgivning) skal oplyses klart og utvetydigt, at salgsfremmende konkurrencer og spil klart skal kunne identificeres som sådanne, at uopfordret kommerciel kommunikation via e-mail klart og tydeligt skal fremtræde som sådan, og at man skal kunne framelde sig modtagelsen af sådanne henvendelser.

Direktivets bestemmelser i artikel 11 om mulighed for at kunne finde og rette indtastningsfejl og om ordrebekræftelse, der skal gives uden unødig forsinkelse og elektronisk, og at ordren og bekræftelsen af deres modtagelse anses for modtaget, når parterne, som 
de er adresseret til, har adgang til dem, er ligeledes af central betydning for mikrobetalinger, idet dette kræver, at forbrugeren, selv ved indgåelse af aftalen via overtakserede SMS'er, har krav på en ordrebekræftelse, der giver mulighed for at finde og rette eventuelle misforståelser umiddelbart i forbindelse med aftaleindgåelsen.

Endelig er reglerne om formidleransvar for tjenesteyderen af betydning, bl.a. idet reglerne medfører, at domstolene og administrative myndigheder kan pålægge formidlerne af aftaler med mikrobetalinger at forhindre (yderligere) overtrædelser fra udbyderne af salget af varer og tjenesteydelsers side. Hvis en tjenesteudbyder således har udfærdiget et aftalekoncept, der er i strid med gældende lovgivning, f.eks. reglerne om god markedsføringsskik, eller som ikke giver de krævede oplysninger, kan formidleren pålægges at forhindre yderligere transmission over telefon- eller Internettet. De kan dog ikke i medfør af direktivet om e-handel pålægges nogen generel overvågningsopgave.

\subsection{Direktiv om fjernsalg af finansielle ydelser til forbrugerne (EP og $\mathrm{R}$ dir 2002/65/EF)}

\subsubsection{Direktivets indhold}

Direktivet om fjernsalg indeholder hovedreglerne for aftaler om fjernsalg af varer og tjenesteydelser, men finansielle tjenesteydelser er ikke omfattet af dette direktiv. Dette "hul" i reguleringen af forbrugerbeskyttelsen i forbindelse med aftaler indgået i forbindelse med fjernsalg lukkes ved direktiv om fjernsalg af finansielle ydelser til forbrugerne (som skal fortolkes og anvendes i overensstemmelse med direktivet om e-handel, jf. betragtning nr. 6 til direktivet).

Formålet med direktiv om fjernsalg af finansielle tjenesteydelser er dels at tilnærme medlemsstaternes love og administrative bestemmelser til hinanden, dels at sikre et højt forbrugerbeskyttelsesniveau med henblik på at styrke udviklingen af det indre marked.

Direktivet regulerer fjernsalgsaftaler om finansielle tjenesteydelser, hvorved forstås enhver aftale, der har karakter af bankkredit, eller betalingstjenesteydelse, hvis aftalen er indgået mellem en forbruger og en leverandør under anvendelse af en eller anden form for fjernkommunikationsteknik i forbindelse med et system til fjernsalg eller fjernlevering af tjenesteydelser drevet af leverandøren.

Hovedindholdet i direktivet er opstilling af minimumskrav til oplysninger, som forbrugeren skal have inden indgåelse af fjernsalgsaftalen, og om meddelelse af aftalevilkår og -betingelser samt forhåndsbesked (artikel 3, 4 og 5). Hertil kommer en 14 dages fortrydelsesret regnet fra aftalens indgåelse eller fra den dag, forbrugeren modtog aftalevilkårene på papir eller andet varigt medium.

Undtaget fra fortrydelsesretten er bl.a. handel med fremmed valuta, varer og andre finansielle tjenesteydelser, som næppe har interesse for mikrobetalingsproblematikken.

"Varigt medium" defineres i artikel 2, litra f, som en indretning, som sætter forbrugeren i stand til at lagre oplysninger sendt til ham personligt på en måde, der muliggør senere konsultation i en periode, som er afpasset efter oplysningernes formål, og som giver mulighed for uændret gengivelse af de lagrede oplysninger.

Fortrydelsesretten finder ikke anvendelse på aftaler, som efter forbrugerens udtrykkelig ønske er blevet helt opfyldt af begge parter, inden forbrugeren udøver sin fortrydelsesret. 
De oplysninger, som leverandøren af den finansielle ydelse skal give i medfør af artikel 3 , er dels oplysninger 1) om leverandøren (navn og adresse m.m.), 2) om den finansielle tjenesteydelse (dens vigtigste karakteristika, den samlede pris, der skal betales, risici som følge af aftalen, betalings- og leveringsbetingelser m.m.) samt 3) om fjernsalgsaftalen, fortrydelsesretten og dens udøvelse m.m.) og endelig 4) om klageadgang m.v.

Hvis der anvendes taletelefoni, er der i artikel 3, stk. 3, opstillet begrænsede krav til oplysningspligten. I så fald skal alene oplyses leverandørens identitet og det kommercielle formål med opkaldet. Herudover kan leverandøren - med forbrugerens udtrykkelige samtykke - nøjes med at give oplysning om navn og stilling på den person, forbrugeren er i kontakt med, tjenesteydelsens vigtigste karakteristika, herunder den samlede pris for tjenesteydelsen, som forbrugeren skal betale til leverandøren, afgifter m.v., og hvorvidt der er fortrydelsesret, dens varighed og betingelserne for at gøre den gældende. Leverandøren skal også ved taletelefoni underrette forbrugeren om, at der kan fås andre oplysninger efter anmodning og angive disses karakter.

Under alle omstændigheder skal leverandøren give de fuldstændige oplysninger på papir eller andet varigt medium straks efter fjernsalgsaftalens indgåelse, hvis aftalen er indgået på forbrugerens anmodning via et medium, som ikke gør det muligt at udlevere samtlige oplysninger, før aftalen indgås, jf. artikel 3, stk. 3, jf. artikel 5, stk. 1 og 2. Hvis en enkelt aftale indebærer flere på hinanden følgende transaktioner eller en række enkeltoperationer af samme karakter over en vis periode, anvendes direktivet kun på den første aftale og ikke på de efterfølgende successive operationer eller enkeltoperationer af samme karakter over en vis periode. Dette betyder f.eks., at direktivet finder anvendelse på en fjernsalgsaftale vedrørende tilslutning til et mikrobetalingssystem, men ikke på de senere enkeltstående transaktioner.

\subsubsection{Direktivet set i forhold til mikrobetalinger}

Direktivet om fjernsalg af finansielle ydelser vil omfatte indgåelsen af distanceaftaler om tilslutning til betalingssystemer omfattende mikrobetalinger samt enkeltstående aftaler med mere end 1 års intervaller (artikel 1, stk. 2). Direktivet er i højere grad end det generelle fjernsalgsdirektiv indrettet på fjernsalg via nyudviklede fjernkommunikationsmetoder. Således er der en særlig regulering af de oplysninger, der skal gives ved aftaler indgået via taletelefoni (hvor mængden af de oplysninger, der skal gives umiddelbart begrænses). Der er ligeledes fastlagt en definition af begrebet "varigt medium", der bl.a. omfatter disketter, Cd-rom, DVD'er og harddisken på forbrugerens computer, hvorpå den elektroniske post lagres, mens det tekniske niveau i mobiltelefonen for tiden udelukker, at dette kan omfatte SMS'er. Definitionen udelukker ikke, at en webside på Internettet kan indrettes på en måde, der opfylder kravene i dette og andre direktiver.

Direktivet finder i forbindelse med mikroaftaler anvendelse ved indgåelsen af tilslutningsaftalen men omfatter også enkeltstående aftaler om leverance af finansielle tjenesteydelser, hvis der er lang tid imellem disse (mere end 1 år). Her findes også reglen i artikel 9, der forbyder uanmodede tjenesteydelser. Det forbydes således at levere finansielle tjenesteydelser til en forbruger uden forudgående anmodning herom, når denne levering indebærer, at forbrugeren skal betale for den. Forbrugeren skal fritages for enhver forpligtelse i tilfælde af uanmodet levering, idet manglende reaktion fra forbrugeren ikke må anses for samtykke.

En leverandør må således ikke uanmodet lade sit mikrobetalingssystem installere på forbrugerens computer eller udvide mobiltelefonens funktioner med den finansielle 
ydelse, et betalingssystem er. Han må heller ikke uden samtykke henvende sig til forbrugeren ved hjælp af opkaldsautomat eller fax.

Direktivet fastlægger endvidere præceptivt fortrydelsesret for forbrugeren samt pligt til, at medlemsstaterne skal påse, at det er muligt for en forbruger at anmode om annullering af en betaling, hvis et betalingskort er blevet anvendt svigagtigt $i$ forbindelse med en fjernsalgsaftale og at blive krediteret for eller få refunderet hele det betalte beløb, hvis der er tale om en sådan svigagtig anvendelse.

Der findes ikke en tilsvarende regel for betaling via overtakserede SMS'er og MMS'er.

Direktivet skal være implementeret senest den 9. oktober 2004.

\subsection{Direktiv om urimelige kontraktvilkår i forbrugeraftaler (R dir 93/13)}

\subsubsection{Direktivets indhold}

Direktiv om urimelige aftalevilkår gælder generelt for alle aftaler, der indgås mellem erhvervsdrivende og forbrugere. Direktivet indeholder dels en række eksempler på, hvilke vilkår, der må anses for urimelige, dels en regel om, at ikke-individuelt forhandlede vilkår anses for urimeligt, hvis det til trods for kravene om god tro (hæderlig forretningsskik) bevirker en betydelig skævhed i parternes rettigheder og forpligtelser ifølge aftalen til skade for forbrugeren.

\subsubsection{Direktivet set i forhold til mikrobetalinger}

Direktivet lægger en generel "bund" i forhold til, hvilke vilkår der kan aftales imellem erhvervsdrivende og forbrugerne. Dette betyder bl.a., at de vilkår, der aftales ved forbrugerens tilslutning til mikrobetalingsmidler og ved aftaler med betaling hermed er underlagt domstolenes censur, hvorved aftalens rimelighed skal vurderes under hensyn til, hvilken type aftale, der er tale om, og hvilke type varer eller tjenesteydelse aftalen omfatter. En sådan vurdering er ikke særegen for mikrobetalinger, men domstolene vil formentlig bl.a. medtage i vurderingen, hvilken målgruppe reklamematerialer og aftalevilkår henvender sig til og under hvilke forhold, aftalen indgås (tid, sted, medie). Dette stiller krav til den, der udfærdiger aftalen, idet det må erindres, at forbrugeren ved indgåelse af mikroaftaler ofte ikke har hverken tid, mulighed for eller anledning til at sætte sig ind i lange og komplicerede kontrakter.

\subsection{Direktiv om forbrugerkredit (R Dir 87/102 som senest ændret ved EP/R dir 98/7)}

\subsubsection{Direktivets indhold}

Direktivet om forbrugerkredit finder anvendelse på aftaler om forbrugerkredit, jf. artikel 1, dog med undtagelse af kreditaftaler i henhold til hvilke, der ikke skal betales renter og andre omkostninger eller kreditter i form af træk på en løbende konto bevilget af et kredit- eller finansieringsinstitut, idet denne undtagelse dog ikke gælder kreditkortkonti, jf. artikel 2. For sådanne kreditter om løbende konto gælder dog artikel 6, der stiller 
krav om, at forbrugeren skal have oplysning om kredittens eventuelle maksimumsbeløb, om den årlige rente og andre omkostninger samt ændringer heri.

Aftaler om præstation af en løbende ydelse, når forbrugeren har ret til at betale sådanne ydelser gennem rater, så længe de præsteres, anses ikke for at være kreditaftaler i henhold til dette direktiv. Dette fritager aftaler om løbende leverancer af f.eks. telefonabonnement fra direktivet, jf. artikel 2, stk. 1, litra e. Hvis der er kreditkort tilknyttet aftalen, er den dog omfattet af direktivet.

Endvidere er kreditaftaler om mindre end 200 ECU undtaget, jf. artikel 2, stk. 1, litra f.

Disse to undtagelser vil formentlig medføre, at en stor del af de aftaler, der vedrører mikrobetalingsmidler, ikke vil være omfattet af direktivet om forbrugerkredit.

For de kreditaftaler, der er omfattet af direktivet, gælder dels at kreditaftaler skal oprettes skriftligt med en genpart heraf til forbrugeren, og at aftalen skal indeholde en række oplysninger bl.a. om årlige omkostninger i procent, om tilbagebetalingsbeløb og om det samlede beløb, forbrugeren i alt skal betale for kreditten.

Direktivet bestemmer endvidere, at forbrugeren har ret til at indfri en kreditaftale forud for forfaldstidspunktet, og at forbrugeren kan gøre enhver indsigelse gældende over for en tredjemand, som har fået overdraget kreditgiverens fordring på forbrugeren.

\subsubsection{Direktivet set i forhold til mikrobetalinger}

De undtagelser fra direktivet, som er anført i artikel 2, litra e, om løbende ydelser og om småkreditter (under 200 ECU), vil formentlig omfatte en stor del af aftalerne om mikrobetalinger. I de tilfælde, hvor direktivet gælder, får dette nogen indflydelse på den retlige regulering. Ved de aftaler om tilslutning til mikrobetalingssystemer, der måtte angå beløb, der gør, at de er omfattet, eller som angår løbende kredit med kreditkort, vil kravet om skriftlighed og udlevering af genpart af aftaler til forbrugeren betyde, at det vil være forholdsvist nemt for den erhvervsdrivende at opfylde kravene til oplysningspligten vedrørende indgåelse af kreditaftaler. Ved indgåelsen af sådanne aftaler skal kreditgiver i mikroaftaler opfylde samme krav som kreditgiveren i andre typer kreditaftaler.

\subsection{Kommissionens henstilling om transaktioner med elektroniske betalingsmidler, især forholdet mellem udsteder og indehaver (Henstilling 97/489/EF)}

Kommissionen er den 30. juli 1997 kommet med en henstilling om transaktioner med elektroniske betalingsmidler, især forholdet mellem udsteder og indehaver, der med udgangspunkt i formålet at sikre et fuldt fungerende indre marked peger på, at den kraftige innovation og hastige teknologiske udvikling også gælder transaktioner ved elektroniske betalingsmidler og den elektroniske handel. Kommissionen har på den baggrund udfærdiget et regelsæt, der ønskes indført som minimumsregulering i medlemsstaterne og EØS-landene.

Formålet med henstillingen er at sikre et højt forbrugerbeskyttelsesniveau inden for elektroniske betalingsmidler og at fremme forbrugernes tillid til og detailhandlernes accept af elektroniske betalingsmidler.

Kommissionen fastlægger en række minimumskrav vedrørende informationer, forpligtelser og ansvar for udsteder og indehaver. Informationskravet gælder både ved indgåel- 
sen af en kontrakt om tilslutning til betalingsmidlet og i forbindelse med de enkelte transaktioner, ligesom det fastslås, at det er vigtigt, at der føres fortegnelser over transaktioner med elektroniske betalingsmidler, således at det er muligt at efterspore transaktionerne og rette eventuelle fejl. Bevisbyrden for, at en transaktion er korrekt registreret og konteret og ikke har været berørt af eventuelle tekniske sammenbrud eller andre uheld, pålægges udstederen.

Indehaveren må ikke annullere en ordre, som han/hun har givet ved hjælp af sit elektroniske betalingsmiddel, undtagen hvis beløbet ikke var fastlagt, da ordren blev givet. Henstillingen indeholder endvidere en regulering af udstederens forpligtelse i tilfælde, hvor en kontoindehavers betalingsinstrukser ikke er blevet effektueret eller er blevet effektueret mangelfuldt, samt for betalingsinstrukser, som indehaveren ikke har givet tilladelse til.

Kommissionen fører tilsyn med gennemførelsen af denne henstilling og vil eventuelt, hvis den finder gennemførelsen utilfredsstillende, stille forslag til den fornødne bindende lovgivning om de spørgsmål, der er omhandlet i henstillingen.

Henstillingen er indholdsmæssigt meget tæt på de regler, der findes for de tilsvarende områder i den danske lov om betalingsmidler, men vil ikke blive gennemgået i detaljer $\mathrm{i}$ denne rapport.

\subsection{Meddelelse fra Kommissionen til Rådet og Europaparlamentet om en ny retslig ramme for betalinger i det indre marked.}

Denne meddelelse fra Kommissionen sigter på at videreudvikle effektive betalingstjenester, konkurrence på lige vilkår rimelig beskyttelse af brugerne af betalingstjenester, betalingssikkerhed og retssikkerhed for alle parter, som berøres af betalingsvirksomhed. Meddelelsen er et udspil til samråd med/høring af alle berørte parter om de almene mål og principper, der skal ligge til grund for modernisering og forenkling af den retslige ramme, som skal gælde for betalingstjenester i detail ledet i det indre marked. Denne høring skal lede frem til, at kommissionen præsenterer passende og rimelige forslag til en ny retslig ramme for betalinger. Meddelelsen opregner en række vejledende principper for et kommende direktivforslag. Disse principper er bl.a. effektivitet, sikkerhed, konkurrence på lige vilkår og forbrugerbeskyttelse på et højt niveau.

De forbrugerbeskyttelseshensyn, der nævnes, er krav på koncentreret, sammenhængende og anvendelig information før og efter udførelsen af en betalingstransaktion. Der nævnes her, at en af de vanskeligste opgaver bliver at finde en rimelig balance mellem informationsindholdet og informationsvolumen, så at brugeren kan forstå og få kendskab til sine rettigheder og pligter.

Herefter nævnes retslig beskyttelse, hvis en betalingstransaktion ikke er udført, er udført fejlagtigt, eller er sket uden forbrugerens tilladelse.

Retslig beskyttelse må også overvejes ved distancehandel og den øgede brug af direkte debitering (f.eks. ved betaling over telefonen), samt når elektroniske betalingssystemer ikke findes tilgængelige.

Endelig nævnes muligheden for alternativ tvistløsning.

Høringssvar skal være kommet frem inden den 15. januar 2004, og derefter vil der blive udarbejdet et nyt direktiv om betalinger. 


\section{Relevant nordisk regulering}

\subsection{Danmark}

\subsubsection{Oversigt}

Der gælder i Danmark love og enkeltregler, som regulerer fjernsalg, aftaler om elektronisk (fjern)handel og -betaling, umyndiges formueretlige aftaler, udbud af teletjenester, registrering af personoplysninger og udbud af betalingssystemer, som er af relevans for det samlede overblik over den retlige regulering af mikroaftaler. I det følgende vil disse love dog kun blive inddraget i det omfang, de har særlig interesse for mikrobetalinger. Derudover vil der kun blive givet en kort omtale af lovens indhold.

Der findes ud over denne lovgivning frivillige brancheaftaler, bl.a. indgået af teleselskaberne. Disse aftaler søger at tage højde for nogle af de problemer, der ikke er lovgivet for.

\subsubsection{Offentligretlig regulering}

Den væsentligste offentligretlige, generelle regulering af området vedrørende mikroaftaler er markedsføringsloven og personoplysningsloven. Herudover indeholder lov om betalingsmidler og lov om e-handel en række specialregulerende regler, bl.a. en pligt til at anmelde betalingssystemer til Forbrugerombudsmanden, oplysningspligt og om identifikation af kommerciel reklame.

Lov om konkurrence- og forbrugerforhold på telemarkedet med tilhørende bekendtgørelser regulerer informations- og indholdstjenester med integreret taksering, men kun delvist de indholdstakserede (overtakserede) SMS-betalinger, der ikke har integreret taksering, men som er at anse som et betalingsmiddel.

Markedsføringsloven gælder overalt i markedsføringen i Danmark. I forhold til mikrobetalinger er følgende regler af særlig interesse: Generalklausulen i $\S 1$, vildledningsforbudet i $\S 2$, oplysningspligten i $\S 3$, reglen om anvendelsen af elektronisk reklame i $\S$ 6 a og Forbrugerombudsmandens mulighed for at føre tilsyn med, at loven overholdes, herunder ret til at kræve meddelt alle oplysninger, som skønnes nødvendige for denne virksomhed, jf. $\S 15$.

Generalklausulen om god markedsføringsskik i $\S 1$ betyder i relation til mikrobetalinger, at Forbrugerombudsmanden kan stille krav til udbydere af betalingssystemer om, at disse skal indrettes sikkert, overskueligt og i overensstemmelse med god markedsføringsskik. Dette krav findes også i betalingsmiddellovens generalklausul i lovens $\S 4$, der er specialregel for betalingsmidler. Såfremt udbyderne af betalingssystemet samarbejder om salg af mikroydelser med indholdsudbydere (f.eks. teleselskabernes salg af overtakserede SMS-tjenester) eller leverandører af varer eller tjenesteydelser, giver markedsføringslovens $\S 1$ hjemmel til at kræve, at systemudbyderen er ansvarlig for, hvorledes realydelsesleverandøren indretter sin markedsføring, f.eks. for så vidt angår relevante oplysninger om ydelsen, afbestillingsmulighed, hvem der er leverandører af 
ydelsen m.v. Herudover er systemudbyderen ansvarlig for egne tiltag, f.eks. i form af hyppighed og udformning af regninger, overholdelse af saldokontrolaftaler, serviceydelser over for brugerne i forbindelse med oplysning om, hvem indholdsleverandøren er, og hvorledes der kan klages over denne.

Indholdet af de ydelser, der kan erhverves ved betaling med mikrobetalinger, er som al anden markedsføring, underkastet kravet om god markedsføringsskik. Særligt i forhold til markedsføring over for børn og unge kan Forbrugerombudsmanden gribe ind og stille krav om, at indholdet ikke må være skadeligt eller krænkende. Her vil især indholdsydelser af seksuel eller voldelig karakter være i fokus, men også andet indhold kan være omfattet. Dette gælder f.eks. indhold, der animerer børn og unge til umådeholdent forbrug, til at plage forældre om, at de skal købe bestemte ydelser, eller som får barnet/den unge til at føle, at man må købe ydelsen for at kunne begå sig socialt eller som på utilbørlig måde påvirker børn/unge politisk, religiøst eller på anden måde. Også manglende overskuelighed $\mathrm{i}$ informationerne eller manglende eller skjulte oplysninger kan være $\mathrm{i}$ strid med markedsføringslovens $\S \S 1$ og 3 .

Bekendtgørelse om informations- og indholdstjenester med integreret taksering, der dog ikke omfatter de overtakserede SMS/MMS'er, bestemmer vedrørende tids- og opkaldstakserede tjenester, at de i visse kategorier ikke må være uegnede for børn under 16 år og ikke må beskrive seksuelle eller voldelige forhold og ikke må formidle kontakt eller links til andre tjenester med sådant indhold. Visse kategorier af tjenester må heller ikke indeholde konkurrencer.

Markedsføringslovens $\S \S 2$ og 3 forbyder vildledende markedsføring og opstiller et generelt krav om, at den erhvervsdrivende skal give "forsvarlig vejledning" vedrørende ydelsen.

En erhvervsdrivende må ikke uanmodet rette henvendelse til nogen ved brug af elektronisk post (e-mail og SMS) med henblik på afsætning af bl.a. varer og tjenesteydelser, jf. markedsføringslovens $\S 6$ a, stk. 1. Dette betyder, at det ikke er tilladt at udsende reklamer og tilbud uopfordret. Dog må en erhvervsdrivende nu (efter 25. juli 2003) markedsføre egne produkter via SMS og e-mail til de kunder, hvorfra den erhvervsdrivende har modtaget deres elektroniske adresse i forbindelse med salg af en vare eller en tjenesteydelse. Betingelserne for lovligheden af sådan markedsføring er dog, at kunden har mulighed for let og gebyrfrit at frabede sig dette, både i forbindelse med afgivelsen af adressen til den erhvervsdrivende og ved efterfølgende henvendelser, jf. markedsføringslovens $\S 6 \mathrm{a}$, stk. 2 .

$\S 6$ a, stk. 2, betyder, at de erhvervsdrivende, der én gang har fået kunders e-mailadresse eller telefonnummer i forbindelse med køb af SMS-baserede ydelser, vil kunne fortsætte med at sende e-mails og SMS/MMS'er til kunderne med reklamer og tilbud, lige ind til kunden siger fra over for sådan markedsføring. Dette angår også salg af overtakserede SMS/MMS'er.

Lov om tjenester i informationssamfundet, herunder visse aspekter af elektronisk handel (e-handelsloven) finder anvendelse på mikroaftaler, bortset fra aftaler vedrørende spil, lotterier og væddemål, jf. e-handelslovens $\S 1$. (Med spil menes deltagelse i spil med mulighed for at vinde penge eller andet, ikke f.eks. computerspil af diverse arter, der er ren leg uden mulighed for gevinst)

Kommerciel kommunikation via elektroniske medier skal udformes og præsenteres, så det tydeligt fremgår, at der er tale om kommerciel kommunikation (reklame, tilbud m.v.). Det skal tydeligt fremgå, på hvis vegne den kommercielle kommunikation udsendes, og - i det omfang det overhovedet er lovligt - betingelser for at modtage rabatter, 
tilgift og gaver skal være let tilgængelige og fremlægges klart og tydeligt, jf. lov om ehandel $\S 9$, stk. 1 og 2. Det samme gælder for salgsfremmende konkurrencer og spil, der er tilladt.

Lov om e-handel stiller yderligere krav om, at en tjenesteyder skal stille hensigtsmæssige, effektive og tilgængelige hjælpeværktøjer til rådighed for tjenestemodtageren, hvorved denne får mulighed for at rette fejl (lovens $\S 11$, stk. 1).

Dette gælder dog ikke for aftaler, der indgås udelukkende ved brug af e-mail eller SMS/MMS, jf. $§ 13$, forudsat at aftalen er indgået udelukkende ved individuel kommunikation, hvilket ikke er tilfældet, hvis aftalen er indgået på baggrund af kommercielt materiale, som den erhvervsdrivende har udsendt.

En tjenesteyder skal stille kontraktbetingelser og generelle salgsbetingelser til rådighed på en sådan måde, at en tjenestemodtager har mulighed for at oplagre og gengive disse. Dette må medføre, at disse betingelser som minimum skal lægges ud på en webside, hvorfra kunden kan hente dem, idet det ikke vil være tilstrækkeligt at sende dem pr. SMS. formentlig vil de nye telefoners MMS-systemer kunne opfylde kravene til mængden af oplysninger, der skal kunne ses.

Lov om betalingsmidler regulerer en meget stor del af de mikrobetalingsaftaler, der er omfattet af denne fremstilling. Loven, som er den eneste af sin art i de nordiske lande, er en videreudvikling af lov om betalingskort fra 1984.

Lov om elektroniske penge er i det væsentligste en offentligretlig lov, der regulerer forholdene omkring udstederne af elektroniske penge, men reglen i 6 gælder umiddelbart for brugerne. Denne regel medfører, at ihændehaveren af et kort eller andet medium indeholdende elektroniske penge $\mathrm{i}$ gyldighedsperioden og op til et år herefter er berettiget til at anmode om udbetaling af restbeløbet uden fradrag af andet beløb et gebyr afpasset efter de nødvendige omkostninger. Udstederen kan bestemme, at beløb under 25 kr. ikke udbetales.

Lov om betalingsmidler omfatter i medfør af dens $\S 1$ betalingsmidler, der kan benyttes til at erhverve varer eller tjenesteydelser, foranledige overførsel af beløb, hæve penge eller foretage andre betalingstransaktioner. Sådanne betalingsmidler kan være 1) hovekort og betalingskort, som er knyttet til bestemte brugere, 2) andre fysiske legitimationsmidler, som er knyttet til bestemte brugere, og som er beregnet til elektronisk aflæsning, 3) koder og biometriske vaerdier, som er beregnet til at legitimere brugere og 4) elektronisk registrerede fordringer, som udsteder er forpligtet til at indfri på brugers anmodning.

Loven omfatter også forudbetalte betalingsmidler i form af elektroniske penge og betalingsmidler, som brugeren kun kan anvende i det omfang, der forud for anvendelsen af betalingsmidlet er sket indbetaling af midler, som ikke er registreret på en konto, der tilhører brugeren, eller hvor brugeren vederlagsfrit har modtaget en sådan værdi eller har fået forhøjet betalingsmidlets værdi.

Loven gælder ikke for betalingsmidler, der udelukkende udbydes til erhvervsdrivende, hvis udstederen godtgør, at brugeren i tilslutningsaftalen har forpligtet sig til udelukkende at anvende betalingsmidlet erhvervsmæssigt, og udstederen ikke efterfølgende accepterer, at betalingsmidlet anvendes på anden måde.

Anvendelsesområdet for lov om betalingsmidler omfatter både de klassiske betalingskort og hævekort, chipbaserede systemer, rent elektronisk registrerede fordringer, som udsteder er forpligtet til at indfri, og forskellige former for elektroniske penge. Loven omfatter også betalingssystemer med anvendelse af overtakserede SMS/MMS'er, idet 
sådanne betalingssystemer tilknyttet telefonregningen vil være omfattet af $\S 1$, stk. 2 , nr. 2, idet SIM-kortet er et "fysisk legitimationsmiddel", og § 1, stk. 2, nr. 3, idet telefonnummeret er en kode, der legitimerer brugeren. Dette medfører, at også udstedere af sådanne systemer skal anmeldes til Forbrugerombudsmanden, der fører tilsyn med, at der ikke sker overtrædelse af loven, og at udbyderen skal udforme betalingssystemet i overensstemmelse med lovens krav om, at betalingsmidlet skal være sikkert og velfungerende $(\S 4)$, og at der skal gives en lang række oplysninger til brugeren af systemet ( $\S 7$ og 8). Endvidere finder lovens hæftelses- og ansvarsregler samt reglerne om opsigelses- og refusionsret m.v. anvendelse på mikrobetalingssystemerne.

De informationer, den erhvervsdrivende får vedrørende personers private eller økonomiske forhold, skal behandles i overensstemmelse med de krav, der opstilles i lov om behandling af personoplysninger, der gælder generelt for al behandling af personoplysninger, som helt eller delvis foretages ved hjælp af elektronisk databehandling, jf. lovens $\S 1$.

Oplysningerne skal behandles i overensstemmelse med god databehandlingsskik, jf. personoplysningslovens $\S 5$, og mere konkret må behandling af oplysninger kun finde sted, hvis den registrerede har givet sit samtykke hertil, hvis behandlingen er nødvendig af hensyn til opfyldelsen af en aftale, som den registrerede er part i, eller af hensyn til gennemførelse af foranstaltninger, der træffes på den registreredes anmodning forud for indgåelsen af en sådan aftale. Endvidere kan behandling af personoplysninger ske, såfremt behandlingen er nødvendig for, at den dataansvarlige eller den tredjemand, til hvem oplysningerne videregives, kan forfølge en berettiget interesse, og hensynet til den registrerede ikke overstiger denne interesse, jf. personoplysningslovens $\S 6$, stk. 1 .

En virksomhed må i medfør af personoplysningslovens $\S 6$, stk. 2, ikke videregive oplysninger om en forbruger til en anden virksomhed til brug ved markedsføring eller anvende oplysningerne på vegne af en anden virksomhed i dette øjemed, medmindre forbrugeren har givet sit udtrykkelige samtykke hertil.

Samtykke til videregivelse af personoplysninger kan gives generelt, f.eks. ved indgåelse af tilslutningsaftalen vedrørende mikrobetalingssystemer, men samtykket skal være $u d$ trykkeligt. I praksis foretages der ofte en positiv reformulering af dette samtykke, således at begrundelsen for, at samtykke gives, ikke findes i de erhvervsdrivendes mulighed for markedsføring, men i forbrugernes behov for $\mathrm{i}$ fremtiden at blive orienteret om andre/nye/bedre produkter. Hvis formuleringen af samtykket fokuserer for meget på forbrugerens fremtidige muligheder og tilslører, at dette indebærer, at der videregives oplysninger om vedkommendes person, vil det dels være i strid med kravet om udtrykkeligt samtykke, dels være i strid med god databehandlingsskik og god markedsføringsskik.

Ud over disse generelt gældende regler vedrørende registreringer i lov om personoplysninger gælder betalingsmiddellovens $\S 13$, der bl.a. indeholder en særregel om registrering og CPR-nummer i forbindelse med betalingsmidler.

Telelovgivningen med lov om konkurrence- og forbrugerforhold på telemarkedet regulerer også visse forhold vedrørende mikrobetalinger.

Denne lov er bl.a. hjemmel for bekendtgørelse om informations- og indholdstjenester med integreret taksering, som dog ikke er omfattet af denne rapport, idet sådanne informations- og indholdstjenesteydelser ikke er omfattet af begrebet mikroaftaler, men blot er en særlig serviceydelse under telefonabonnementet, som koster ekstra pr. minut (integreret taksering). 
Loven giver endvidere hjemmel for udstedelse af bekendtgørelse om udbud af elektroniske kommunikationsnet og -tjenester (udbudsbekendtgørelsen), der også omfatter de i denne rapport nævnte overtakserede (indholdstakserede) SMS'er og MMS'er. Udbudsbekendtgørelsen omfatter kun delvist forudbetalte kort eller elektroniske kommunikationstjenester, der kan sidestilles hermed.

Udbudsbekendtgørelsen indeholder en række offentligretlige krav bl.a. om oplysninger, opsigelser, saldokontrol m.m. Disse krav vil blive gennemgået sideløbende med de tilsvarende privatretlige krav nedenfor i afsnit 8.1.3.

\subsubsection{Privatretlig regulering}

Den privatretlige lovgivning indeholder regler, der regulerer aftaleindgåelse og aftalevilkår, krav om, hvilke oplysninger, der skal gives før, under og efter en aftale samt om hæftelses- og erstatningsregler.

\subsubsection{Indgåelse af aftale}

Ved indgåelse af aftale om tilslutning til selve mikrobetalingssystemet gælder de generelle regler i aftaleloven, særligt $\S \S 38$ a-d og aftalelovens $\S 36$, der beskytter forbrugeren mod urimelige aftalevilkår og opstiller en formodningsregel om fortolkning til fordel for forbrugeren med aftalevilkår, der ikke er individuelt forhandlet. Disse regler gælder i princippet også for den enkelte mikroaftale/mikrobetaling, men disse retshandler er i sig selv af så ringe økonomisk værdi, at man næppe nogensinde vil se aftalelovens regler påberåbt over for en realydelsesleverandør.

Samme problemstilling gælder for så vidt angår købeloven, der regulerer realydelsens kontraktmæssighed, når der er tale om en vare, men købelovens regler om mangler og forsinkelse og beføjelserne her over for vil næppe heller kommer til anvendelse i nogen retssal for varer, der koster 20-30 kr. Reglerne gælder dog naturligvis ikke desto mindre.

Ud over disse regler gælder udbudsbekendtgørelsens $§ 5$, stk. 1, der kræver, at udbyderen af offentlige elektroniske kommunikationsnet eller -tjenester til slutbrugeren skal sikre, at der foreligger en kontrakt som grundlag for ethvert kundeforhold med en slutbruger. Denne kontrakt skal indeholde en lang række oplysninger. Se herom nedenfor i afsnit 8.1.3.2.

Særligt gælder for børn og unge under 18 år, at de er beskyttet mod at stifte gæld i medfør af vargemålslovens $\S 1$. Dette betyder, at børn og unge ikke kan hæfte for overtræk ved aftaler om mikrobetalingssystemer, der er tilknyttet en konto. Børn og unge vil i et vist omfang kunne indgå aftaler vedrørende forudbetalte mikrobetalingssystemer, som f.eks. taletidskort, elektroniske klippekort m.v., i hvert fald for så vidt de disponerer over selverhvervede midler eller gaver givet til eget brug.

Værgen kan give samtykke til, at barnet/den unge indgår aftale om et almindeligt telefonabonnement, herunder telefonabonnement med mulighed for at sende almindelige SMS'er, men værgen kan ikke give samtykke til, at barnet eller den unge hæfter for gæld ved brug af overtakserede SMS'er, ligesom værgen ikke kan forpligte den mindreårige ved aftaler om kreditkort og betalingskort, der giver adgang til at stifte gæld. Dvs. at hvis værgen har givet samtykke til en abonnementsaftale, hvor der er inkluderet overtakserede SMS/MMS'er, er denne del af aftalen ikke bindende, og barnet /den unge kommer kun til at betale for de ydelser, der er købt via overtakserede SMS'er i det om- 
fang, de har været til nytte for den mindreårige. Og det er hverken ringetoner, horoskoper, vittigheder eller logoer, medens f.eks. transport med bus og tog kan være det.

Om værgen hæfter for den mindreåriges brug af overtakserede SMS/MMS'er er tvivlsomt ud fra kautionsretlige principper, hvorefter kautionisten kun er forpligtet, såfremt hovedmanden også er det. Værgen kan dog være ansvarlig ud fra erstatningsretlige overvejelser, såfremt han har udvist culpøs adfærd i forhold til udbyderen af betalingssystemet eller betalingsmodtageren.

Som nævnt ovenfor i afsnit 6.8 er beskyttelsen af mindreårige i medfør af værgemålsloven mindre praktisk anvendelig, idet udbyderne af mikrobetalingssystemer kræver en myndig persons underskrift som kontraktsansvarlig i stedet for den mindreårige. Hermed er det den voksne, der selv er ansvarlig for den mindreåriges brug af mikrobetalinger.

Det er et særligt aftaleretligt spørgsmål, om der er indgået aftale om mindreåriges brug af overtakserede SMS/MMS'er. Såfremt der ikke oprindelig var denne facilitet i aftalen, kræves der en særlig tillægsaftale, jf. også udbudsbekendtgørelsens $\S 5$, stk. 1, for at den kontraktsansvarlige voksne bliver forpligtet. I modsat fald vil denne del af aftalen i overensstemmelse med almindelige aftaleretlige principper ikke være vedtaget af den kontraktsansvarlige, og han vil ikke være bundet af den mindreåriges brug af overtakserede SMS'er.

Forbrugerombudsmanden har i et brev til de danske teleudbydere gjort klart, at retsstillingen er som ovenfor fremstillet, og at der kræves fremsendt og tiltrådt en særlig tillægsaftale vedrørende overtakserede SMS'er, for at den voksne kan afkræves betaling herfor.

\subsubsection{Oplysningspligten inden aftalen indgås}

Oplysningspligten vedrørende mikroaftaler er i dansk ret fastslået i flere af de love, der regulerer området. Således findes der regler, der opstiller krav om oplysning i lov om betalingsmidler, lov om e-handel, forbrugeraftaleloven, telelovgivningen og i kreditaftaleloven. Kravene til de oplysninger, den erhvervsdrivende skal give, angår såvel markedsføring inden aftalens indgåelse som forholdene ved aftaleindgåelsen og den løbende forpligtelse til at afgive kvittering og kontooversigter.

Lov om betalingsmidler indeholder i $\S 4$ en generalklausul, der kræver, at betalingssystemer skal indrettes og virke således, at der sikres brugeren gennemsigtighed, frivillighed, beskyttelse mod misbrug samt fortrolighed om brugerens anvendelse af betalingsmidlet. Forbrugerombudsmanden skal ved forhandling søge forholdene ændret, hvis betalingssystemet ikke lever op til kravene i loven.

Lovens $\S 7$ kræver, at udsteder skal stille informationsmateriale til rådighed for brugeren $\mathrm{i}$ forbindelse med indgåelse af aftale om adgang til at anvende et betalingsmiddel. Dette materiale skal i et let og forståeligt sprog sætte brugeren i stand til at anvende betalingsmidlet på en sikker og hensigtsmæssig måde og oplyse om typiske omkostninger ved anvendelsen af betalingsmidlet. Materialet skal særligt gøre opmærksom på de sikkerhedsmæssige krav, som brugeren skal efterleve, samt hvilket ansvar brugeren kan ifalde ved tredjemands misbrug af betalingsmidlet. De beskrivelser, der skal gives, skal være præcise og tilstrækkelige nok til, at forbrugeren kan få overblik og forståelse for sine pligter og rettigheder ifølge aftalen.

Lov om e-handel indeholder en række offentligretlige regler om oplysningspligt, herunder generel i $\S 7$, hvorefter en tjenesteyder skal give oplysning om tjenesteyderens navn, 
fysiske adresse, e-postadresse samt andre oplysninger, der gør det muligt at kontakte og kommunikere med tjenesteyderen samt visse oplysninger om tjenesteyderens virksomhed og en henvisning til de faglige regler, der måtte gælde.

Lov om e-handel kræver generelt, at prisen skal angives klart og tydeligt, når der gives oplysning om pris. Det kræves ikke, at prisen oplyses, men dette følger af andre regler i forbindelse med ordreafgivelsen

Inden en ordre afgives, kræver e-handelslovens $\S 10$, at en tjenesteyder klart, forståeligt og tydeligt skal give tjenestemodtageren oplysning om de forskellige led i forbindelse med kontraktens indgåelse, om kontrakten bevares af tjenesteyderen og om mulighederne for at finde og rette indtastningsfejl. Endvidere skal oplyses om de sprog, kontrakten kan indgås på, og hvilke relevante adfærdskodekser tjenesteyderen er tilsluttet samt den elektroniske adgang til disse.

Inden en ordre afgives, skal tjenesteyderen give tjenestemodtageren tekniske muligheder for at finde og rette indtastningsfejl, og tjenesteyder skal give tjenestemodtager mulighed for at kunne lagre eller gengive kontraktbetingelser og generelle salgsbetingelser, jf. e-handelslovens $\S 11$.

Loven stiller ikke specificerede krav om, hvorledes oplysningerne skal gives. Oplysninger givet på en internetside og ved e-mail kan opfylde lovens krav, men loven tager ikke stilling til, om oplysninger givet via SMS er tilstrækkelige. Således som SMS'er rent praktisk er udformet i de fleste mobiltelefoner i dag, vil de næppe kunne opfylde lovens krav til oplysninger og lagring/gengivelse heraf, medens kommende "generationer" af mobiltelefoner muligvis vil blive indrettet således, at dette vil kunne blive tilfældet.

Om det vil være tilstrækkeligt til opfyldelse af oplysningskravene i $\S 7$ at henvise til en internethjemmeside, hvis aftalen skal indgås via SMS, er tvivlsomt, idet lovens ord i $\S \S$ 7 og $11 \mathrm{er}$, at tjenesteyderen "skal give oplysning om". Det er således næppe tilstrækkeligt, at der gives adgang til oplysning om prisen ( $(8)$, betingelserne for at modtage reklametilbud ( $(9)$, de forskellige tekniske led i forbindelse med kontraktens indgåelse, muligheden for at finde og rette indtastningsfejl og adfærdskodekser, eventuel opbevaring af kontrakten og kontraktsprogene (§ 10) m.v. § 7, stk. 3, kræver dog kun, at der skal være en let tilgængelig og vedvarende adgang til de oplysninger, der er omfattet af $\S 7$ (navn, adresse, CVR-nummer, brancheorganisation m.v.), hvorfor det for disse oplysningers vedkommende muligvis vil være tilstrækkeligt med en henvisning til en hjemmeside indeholdende oplysningerne.

Direktivets tekst i artikel 5 taler om "let, umiddelbar og vedvarende adgang". Dette er sprogligt set ikke præcist det samme som lov om e-handel $\S 7$, stk. 2, "let tilgængelig og vedvarende". Direktivets krav synes strengere end den danske lovtekst.

Telelovgivningen indeholder i bekendtgørelsen om udbud af elektroniske kommunikationsnet og -tjenester $\S 6 \mathrm{krav}$ om, at udbydere af offentlige kommunikationsnet eller tjenester til slutbrugeren på forespørgsel skal oplyse om de forhold, der er nævnt i $\S 5$, stk. 2 (bl.a. udbyders navn og adresse, relevante priser, aftalevilkår m.v.). Dette kan dog ske ved at stille et telefonnummer med en oplysningstjeneste til rådighed for brugeren.

Forbrugeraftaleloven indeholder i kapitel 4 regler om fjernsalg, der gælder for aftaler om køb af varer og tjenesteydelser og løbende levering af varer eller tjenesteydelser, når aftalen indgås ved brug af fjernkommunikation, og uden at parterne mødes og indgår som led $i$ et system for fjernsalg. 
Forbrugeraftalelovens $\S 11$ indeholder krav om oplysninger, den erhvervsdrivende skal give, inden der indgås en aftale. Disse oplysninger er bl.a. den erhvervsdrivendes navn og adresse, prisen på varen, varens/tjenesteydelsens karakter og væsentligste egenskaber, oplysning om fortrydelsesret, vilkår om betaling, levering eller anden opfyldelse af aftalen samt om en eventuel uopsigelighedsperiode. Disse oplysninger skal gives $i$ rimelig tid, og inden der indgås en aftale, jf. forbrugeraftalelovens $\S 11$, stk. 2, og oplysningerne skal gives på en måde, der er "egnet under hensyn til den anvendte kommunikationsteknik, og som tager særligt hensyn til umyndige personer". Det er næppe tilstrækkeligt, at oplysningerne om varen og dens pris, om uopsigelighed, fortrydelsesret, den erhvervsdrivendes identitet m.v. gives alene med henvisning til en internetadresse. Mange - også unge mennesker - har ganske vist i dag (let) adgang til Internettet, men formålet med oplysningerne om bl.a. fortrydelsesretten, om varen og dens pris m.v. forspildes, hvis disse oplysninger skal findes i et andet medium og et andet sted, end der, hvor aftalen indgås. Det må forventes, at mange f.eks. ikke vil få set oplysningerne i tide til at kunne anvende en fortrydelsesret. Hvis de væsentligste af oplysningerne gives i ordrebekræftelsen (jf. nedenfor), vil henvisning til en internetside dog kunne være tilstrækkeligt, såfremt denne indrettes, så den f.eks. ikke kan ændres af nogen af parterne, idet hverken direktivet eller forbrugeraftaleloven stiller krav om skriftlighed, og oplysningerne skal tilpasses den anvendte kommunikationsteknik.

Kreditaftaleloven stiller krav om en lang række oplysninger, der skal gives skriftligt, jf. kreditaftalelovens $\S \S 8,9$ og 10 . Hvis en aftale om et mikrobetalingssystem indebærer mulighed for, at den erhvervsdrivende yder kredit til forbrugeren, hvor det samlede beløb, der skal betales, ved fuld udnyttelse af kontoen overstiger $1.500 \mathrm{kr}$., skal den erhvervsdrivende give disse oplysninger skriftligt. Dette kan også ske elektronisk via en e-mail til forbrugeren.

\subsubsection{Oplysninger m.v. efter aftaleindgåelsen}

Når aftalen, der indebærer mikrobetalingen er indgået, har brugeren efter lov om kreditaftaler krav på en genpart af aftalen, ligesom der i medfør af $\S 11$ skal tilsendes forbrugeren kontoudtog, der skal opfylde lovens krav om bl.a. saldoen ved periodens begyndelse og slutning, størrelsen og tidspunktet for debiteringer og krediteringer i løbet af perioden, den nominelle årlige rente.

Efter lov om betalingsmidler $\S 8$ har forbrugeren krav på kvittering ved enhver transaktion med betalingsmidlet, medmindre brugeren på anden måde har let adgang til oplysninger om, hvorvidt og hvornår den pågældende transaktion er gennemført. Dette må kunne ske via SMS ved telefoniske aftaler ved en e-mail eller på et display ved anvendelse af elektroniske billetter, telefonkort o. lign.

Lov om e-handel stiller i $\S 12$, stk. $1 \mathrm{krav}$ om, at en tjenesteyder uden unødig forsinkelse elektronisk skal bekrofte modtagelsen af en elektronisk ordre. Dette må betyde, at såfremt aftalen er indgået via (overtakseret) SMS, skal der også afgives en ordrebekræftelse på denne måde. Loven opstiller ikke nogen krav til udformningen eller indholdet af denne ordrebekræftelse.

Forbrugeraftaleloven stiller i $\S 11$ a, stk. 1, krav om, at der efter indgåelse af en aftale om fjernsalg skal gives oplysninger om den erhvervsdrivendes navn, adresse, beskrivelse af varen/tjenesteydelsen, prisen, leveringsomkostninger og fortrydelsesret "læsbart på papir eller på et andet varigt medium", hvis disse oplysninger ikke er givet i denne form på et tidligere tidspunkt. Herudover skal der gives oplysning om klageadgang og adgan- 
gen til at anvende fortrydelsesretten. Kravet om varigt medium har været et af problemerne i udviklingen af fjernsalg via mobiltelefoner, således som den tekniske standard er for tiden. Dette kunne dog muligvis løses ved en smidig fortolkning af reglen i $\S 11$, stk. 5, uden at forbrugerbeskyttelsen behøvede at blive svækket. Nogle af de oplysninger, der skal gives efter $\S 11$, stk. 5, kunne forbrugeren uden problemer vente med at få i varig form til senere, mens andre af oplysningerne er af afgørende betydning for forbrugeren i selve købsøjeblikket, men ikke nødvendigvis i "varig" form straks. Forbrugeren har brug for oplysninger om varens pris, egenskaber og fortrydelsesretten for at have et fundament for at bruge/give afkald på fortrydelsesretten, men i denne sammenhæng er det vigtigere, at oplysningerne gives "straks", end at de gives varigt. Den varige form kunne dermed udskydes til senere/andet medium, da formålet hermed giver mulighed for kontrol af forbrug forbrugsstyring og for bevis i tilfælde af uregelmæssigheder eller uenigheder vedrørende de bestilte ydelsers art eller mængde. Et køb via overtakseret SMS kunne herefter afvikles ved fremsendelse af oplysning om varens pris m.v. og om fortrydelsesretten via SMS samt en henvisning til en internetside, hvortil resten af de krævede oplysninger ville kunne findes. Denne internetside skulle indrettes således, at oplysningerne lagres i en periode, svarende til, at forbrugerne kan nå at kontrollere tilsendte kontoudtog, og den må ikke kunne ændres ensidigt af nogen af parterne.

Kravet om oplysningerne gælder ikke ved aftale om tjenesteydelser, hvor bestilling og udførelsen af tjenesteydelsen sker på én gang ved brug af fjernkommunikation. Dette omfatter ydelser, hvor leveringen sker i samme øjeblik som bestillingen, f.eks. opringning til informationstjenester med nyheder, klokken, vejret m.v. Ved de overtakserede SMS/MMS'er er der ikke dette faktiske sammenfald mellem bestilling og udførelsen, idet der går nogle sekunder mellem bestillingen og leveringen. I dette interval er der mulighed for at indskyde et led indeholdende de oplysninger, som forbrugeren har brug for, for at tage stilling til, om han ønsker at modtage det bestilte, eller om fortrydelsesretten skal udnyttes.

I Norge og Sverige fortolkes den tilsvarende bestemmelse baseret på fjernsalgsdirektivets artikel 5, stk. 2 som en undtagelse, der omfatter enkeltstående ydelser. Dette fortolkes dog meget snævert, hvilket også er nødvendigt for ikke at komme i modstrid med direktivet. Se nærmere under afsnit 8.2.3.3. og 8.3.3.3.

Oplysningerne efter aftalens indgåelse skal gives snarest muligt.

Forbrugeraftalelovens $\S 10 \mathrm{~d}$ indeholder enkelte undtagelser fra reglerne om informationspligten, men de mikroaftaler, der indgås for tiden, vil ofte $i k k e$ være omfattet af disse undtagelser. Visse aftaler vil dog være omfattet af undtagelsen. Dette gælder aftaler om transport, som skal effektueres i umiddelbar forlængelse af aftalens indgåelse (så vil det fremgå, inden for hvilket tidsrum/periode tjenesteydelsen skal udføres) og aftaler om rekreative fritidsaktiviteter, hvis det fremgår af aftalen, hvornår tjenesteydelsen skal udføres (§ $10 \mathrm{~d}$, litra 3).

$\S 11$ a, stk. 3, kræver, at de i stk. 1 og 2 nævnte oplysninger skal gives snarest muligt. Dette indebærer, at de ikke behøver at blive givet straks, hvorfor det muligvis vil være tilstrækkeligt at give oplysningerne på en internetside, såfremt kunden har oplyst at have adgang til Internettet. (Dog må e-handelslovens krav om ordrebekræftelse skulle gives direkte over SMS, såfremt aftalen er indgået på denne måde, jf. ovenfor)

Oplysninger om fortrydelsesretten skal dog nødvendigvis gives i umiddelbar sammenhæng med aftalen, såfremt den erhvervsdrivende ønsker, at forbrugeren skal have mulighed for at give samtykke til, at leveringen af tjenesteydelsen skal påbegyndes, uanset at fortrydelsesfristen ikke er udløbet, jf. $\S 12$, stk. 2. Et sådant samtykke kan kun gives, 
såfremt forbrugeren er oplyst om, at der er en fortrydelsesret, som forbrugeren giver samtykke til at afbryde. Forbrugerens accept af levering uden at være oplyst om fortrydelsesretten kan ikke antages at være et stiltiende samtykke til at give afkald på en ret, man ikke kendte.

Telelovgivningen indeholder i udbudsbekendtgørelsens $\S 5$, stk. 2, en lang række krav til oplysninger, som udbyderen af det elektroniske kommunikationsnet eller -tjeneste skal give i den kontrakt, der er grundlag for brugerens tilslutning til kundeforholdet. Denne offentligretlige regulering af kontraktens indhold vedrører den grundlæggende aftale om tilslutning til mikrobetalingssystemet (f.eks. mobilabonnementet). Udbyderen skal bl.a. oplyse sit navn og adresse, alle relevante priser, vilkår for opsigelse og fornyelsen af aftalen, vilkår om kompensation og tilbagebetaling ved mangler ved tjenesten, telemuligheder m.v.

Ved forudbetalte systemer er oplysningspligten begrænset, jf. $\S 5$, stk. 3, således at der kun skal gives de oplysninger, der er relevante for sådanne systemer. Udbyderen skal på forespørgsel over for enhver oplyse om de forhold, der er nævnt i $§ 5$, stk. 2.

Telelovgivningen indeholder ikke krav om oplysninger om, hvorledes eksempelvis en mobiltelefon anvendes på en sikker og hensigtsmæssig måde, ligesom der heller ikke skal oplyses om sikkerhedsmæssige krav og foranstaltninger, ansvaret i forbindelse med misbrug eller om omkostningerne ved at anvende telefonen som betalingsmiddel. Sådanne oplysninger kræves efter betalingsmiddellovens $\S 7$, men teleselskaberne søger i Danmark dispensation fra denne lov.

\subsubsection{Fortrydelsesret}

Lov om forbrugeraftaler har i $\S \S 12-12$ c regler om fortrydelsesret, der dog, jf. $\S 10$ e, ikke gælder ved køb af 1) levnedsmidler og husholdningsartikler, der leveres på forbrugerens bopæl eller arbejdsplads som led i organiseret og regelmæssig udbringning, 2) indkvartering, transport, forplejning - herunder servering og catering, hvis det fremgår af aftalen, hvilken dag eller inden for hvilken bestemt periode tjenesteydelsen skal udføres (som eksempel kan nævnes køb af tog- og busbillet via SMS, og betaling af parkeringsafgift kan muligvis analogiseres til "indkvartering og transport") og aftaler vedrørende rekreative fritidsaktiviteter, herunder underholdnings-, idræts- og lign. kulturbegivenheder, hvis det fremgår af aftalen, hvilken dag eller inden for hvilken bestemt periode, den pågældende tjenesteydelse skal udføres (eksempelvis køb af billetter til forlystelser m.v.). Reglerne om fjernsalg - og dermed fortrydelsesretten - finder endvidere ikke anvendelse på aftaler, der indgås ved hjælp af vareautomater el.lign. automater eller fra automatiserede forretningslokaler.

En stor del af de ydelser, der kan købes ved mikroaftaler, og også de tjenesteydelser, der kan købes via overtakserede SMS/MMS'er, er omfattet af fortrydelsesretten i forbrugeraftalelovens $\S 12$, der giver 14 dages fortrydelsesret, men $\S 12$, stk. 2, indebærer, at forbrugeren ved fjernsalg af tjenesteydelser kan give afkald på fortrydelsesretten, således at levering af ydelsen kan påbegyndes, uden risiko for at forbrugeren fortryder, efter at levering er sket, og således at levering ikke behøver afvente udløbet af de 14 dage. Det samtykke, forbrugeren kan afgive, kræver, at forbrugeren kender den ret, han giver samtykke til at give afkald på, men samtykket kan gives samtidig med, at forbrugeren trykker på en "godkend" eller "ja tak" ordre.

En mikroaftale om en ringetone betalt med overtakseret SMS kan dermed få følgende forløb: Forbrugeren ser en annonce for ringetonen, (som er en opfordring til at gøre tilbud). Forbrugeren sender en SMS med 
bestilling (afgiver tilbud, som binder forbrugeren, når det kommer til den erhvervsdrivendes kendskab). Herefter er der en aftale, der binder forbrugeren, og herefter kan forbrugeren give samtykke til, at levering sker før udløbet af fortrydelsesfristen med den følge, at fortrydelsesretten bortfalder. Den erhvervsdrivende sender derfor en (eller flere) SMS til forbrugeren lydende: Du har bestilt ringetone x, pris $10 \mathrm{kr}$. Du har fortrydelsesret i 14 dage, levering kan ske nu, hvis du giver afkald på denne og sender os en SMS med beskeden "OK". Efter at denne besked er modtaget, kan levering ske. Flere oplysninger på www.ringetonen.dk/12345. På denne adresse findes kundens specifikke oplysninger om tid og pris for købet, den erhvervsdrivendes navn og adresse og hvor forbrugeren kan henvende sig med eventuelle klager (samt oplysning om opsigelse af aftale, hvis det ikke blot er en enkelt ringetone, købet drejer sig $\mathrm{om}$, men et abonnement på ringetoner)

\subsubsection{Haftelses- og ansvarsregler}

Lov om betalingsmidler har i $\S \S 11-12$ regler om hæftelse og ansvar for tredjemands uberettigede brug og for fejlregistrering og konteringsfejl.

Udgangspunktet for hæftelsesansvaret for tredjemands uberettigede brug er, jf. $\S 11$, stk. 1, at udsteder hæfter i forhold til brugeren for tab som følge af andres uberettigede anvendelse af et betalingsmiddel, medmindre andet følger af undtagelserne i § 11, stk. 2-6. Brugeren hæfter under alle omstændigheder kun, hvis transaktionerne er korrekt registreret og bogført.

Brugeren kan komme til at hæfte for tredjemands uberettigede brug, såfremt han har udvist culpøs adfærd, herunder undladt at underrette udstederen i tide om betalingsmidlets bortkomst, eller har overladt betalingsmidlet og PIN-koden til en anden under omstændigheder, hvor brugeren burde have indset, at der var risiko for misbrug. Brugeren hæfter med en selvrisiko på $1.200 \mathrm{kr}$., hvis den hemmelige PIN-kode er anvendt ud fra en formodning om, at dette kun kan ske, hvis brugeren som minimum må have udvist uforsigtighed i brugen af koden, således at den har kunnet aflures.

Særligt vedrørende mobiltelefoner gælder, at disse kan anses for et betalingsmiddel, jf. lov om betalingsmidler $\S 1$, hvis der er indgået aftale om brugen af overtakserede SMS/MMS beskeder. Det er dog ikke afklaret i praksis, hvilke regler forbrugeren kommer til at hæfte efter, hvis tredjemand foretager køb via overtakserede SMS'er. Telefonens SIM-kort kan muligvis analogiseres til et betalingsmiddel med tilknyttet kort med PIN-kode, hvilket ville medføre, at brugeren hæfter efter reglerne om misbrug med anvendelse af pinkode ( $\$ 11$, stk. 2 - 6) men dette er ikke fuldt ud dækkende, da SIMkortets kode ikke vedrører kortets brug som betalingsmiddel, men selve anvendelsen af telefonen. Hvis man foretager denne anvendelse af $\S 11$, stk. 2, kan forbrugeren komme til at hæfte for et forbrug på op til $1.200 \mathrm{kr}$., hvis telefonen mistes i åben tilstand, uden brugeren får givet besked til teleudbyderen.

Brugeren hæfter med op til $8.000 \mathrm{kr}$. for tab som følge af tredjemands uberettigede brug i en række tilfælde, bl.a. hvis brugeren har udvist groft uansvarlig adfærd, har undladt at underrette udsteder snarest muligt efter at have fået kendskab til, at koden er kommet til tredjemands kundskab eller selv har oplyst koden til den, der har foretaget den uberettigede brug.

Brugeren hæfter fuldt ud for tredjemands uberettigede brug af betalingsmidlet, når han har oplyst PIN-koden under særligt graverende omstændigheder.

Udsteder hæfter for ethvert misbrug, der foretages, efter at der er givet underretning om, at der er risiko for, at betalingsmidlet vil blive misbrugt, jf. $\S 11$, stk. 7. Lov om betalingsmidler $\S 11$, stk. 8,2. pkt., indeholder endvidere den regel, at udsteder er ansvarlig, hvis et betalingskort er blevet anvendt svigagtigt i forbindelse med en aftale om fjern- 
salg. Formålet med $\S 11$, stk. 8, 2. pkt., er at friholde brugeren for hæftelsen for selvrisikoen, hvorimod bestemmelsen ikke har til hensigt at friholde brugeren for hæftelsen for misbrug, der er omfattet af $\S 11$, stk. 3, 4 og 6 (hvor brugeren har udvist en vis culpøs adfærd i forbindelse med PIN-koden, overladelse af betalingsmidlet eller undladt at underrette udsteder om risikoen for misbrug).

Bestemmelsen har til formål at gennemføre fjernsalgsdirektivets artikel 8, der vedrører betaling med betalingskort og pålægger medlemsstaterne at sikre, at forbrugeren kan "anmode om annullering af en betaling, hvis et betalingskort er blevet anvendt svigagtigt i forbindelse med en aftale om fjernsalg, og at forbrugeren i tilfælde af svigagtig anvendelse får krediteret eller refunderet de foretagne indbetalinger”.

$\S 11$, stk. 8, 2. pkt., får ikke stor selvstændig betydning ved handel over Internettet, da bruger "i forvejen", dvs. i medfør af $\S 11$, stk. 2, stk. 3 og stk. 4, ikke hæfter for betalinger over Internettet ved overførsel af kortnummer og udløbsdato og eventuelt kontrolnummer, da hæftelsen kun forekommer, hvor PIN-koden er anvendt (stk. 2, 3 og 6), eller at betalingsmidlet har været aflæst fysisk eller elektronisk i forbindelse med misbrugstransaktionen, og at der i tilknytning hertil er anvendt falsk underskrift (stk. 4). Heraf følger, at udstederen i overensstemmelse med udgangspunktet i $§ 11$, stk. 1, hæfter over for brugeren, hvis misbruget finder sted alene ved overførsel af oplysninger om kortnummer og udløbsdato eller via telefonnummeret.

$\S 11$, stk. 8, 2. pkt., kan derimod få betydning, hvis fjernsalget er sket med betaling via mobiltelefonen, hvor PIN-koden er anvendt.

Forbrugerombudsmanden har i december 1996 udstedt retningslinjer vedrørende fjernsalg med betalingssystemer.

Disse regler lyder vedrørende indsigelse om misbrug, ikkelevering og fortrydelsesret:

"Gør kortindehaveren gældende,

a) at en fjernsalgstransaktion hverken er foretaget eller bemyndiget af kortindehaveren,

b) at debiteringen overstiger det beløb, der er aftalt med betalingsmodtageren,

c) at den bestilte ydelse ikke er leveret, eller

d) at kortindehaveren eller den angivne modtager har udnyttet en lovbestemt eller aftalt fortrydelsesret ved at undlade at modtage eller afhente den bestilte ydelse,

skal kortudstederen stille opkrævningen i bero, mens indsigelsens rigtighed undersøges. Kan indsigelsen ikke umiddelbart tilbagevises som uberettiget, må kortudstederen alene opkræve det beløb, som kortindehaveren kan vedkende sig. Er kortindehaveren allerede blevet debiteret for transaktionen, skal det omtvistede beløb straks tilbageføres til kortindehaveren.

En senere debitering/gendebitering må kun ske i det omfang kortudstederen kan godtgøre, at indsigelsen er urigtig.

Bemærkninger:

Bestemmelsen vedrører såvel indsigelser om misbrug som situationer, hvor gennemførelsen af betalingen bringer kortindehaveren ud i en særlig risiko, fordi systemet er indrettet således, at kortindehaveren ikke har mulighed for at holde betalingen tilbage. Forbrugeren bør således risikofrit kunne udnytte en fortrydelsesret ved at undlade at modtage eller afhente den bestilte ydelse, ligesom det ikke er rimeligt, at betalingen gennemføres, hvis den bestilte ydelse ikke leveres.

Det fremgår af bestemmelserne, at det omtvistede beløb skal tilbageføres straks, dvs. i løbet af et par dage efter at kortudsteder er blevet bekendt med indsigelsen".

Disse vejledende regler vil også omfatte mikrobetalinger, som er omfattet af lov om betalingsmidler.

\subsubsection{Saldokontrol}

Mange forbrugere ønsker at kunne holde kontrol med eget eller børns forbrug af mikrobetalingsaftaler, f.eks. i form af telefonforbrug eller anvendelsen af overtakserede 
SMS/MMS'er. Samme ønske har formentlig også en del erhvervsdrivende, der overlader mobiltelefoner til de ansatte til brug til taletelefoni og almindelige SMS'er, men som ikke ønsker, at disse telefoner skal bruges ud over en vis grænse.

Udbudsbekendtgørelsen kræver i $\S 15$, at udbyderen af telefoni via bl.a. mobilkommunikation, og som anvender forbrugsafhængig debitering (løbende konto), skal tilbyde saldooplysning og saldokontrolordning, jf. § 20, ligesom der skal kunne spærres for brug af visse tjenester (informations- og indholdstjenester f.eks., men ikke særskilt spærring for anvendelsen af overtakserede SMS/MMS'er). Saldokontrolordninger kan pålægges gebyr. Teleselskaberne har udviklet to forskellige modeller herfor: Taletidskort/telefonkort og saldomaksimering. Begge tiltag skulle kunne give brugeren kontrol med forbruget.

Det har dog vist sig, at ikke alle teleselskaber administrerer disse ordninger på en sådan måde, at forbrugeren kan regne med, at forbruget rent faktisk er maksimeret. Ved taletidskort til mobiltelefoner har visse teleselskaber ladet brugeren overtrække værdien på taletidskortet for så at trække det merforbrugte beløb på det næste taletidskort, der blev isat mobiltelefonen, ligesom saldomaksimumsaftaler for abonnementsordninger ikke har fungeret tilfredsstillende. Hvis det er forbrugeren selv, der har overskredet aftalte grænser, er der næppe tvivl om, at forbrugeren hæfter for merforbruget. Hvis saldomaksimeringsordningen er aftalt mellem en abonnent og teleudbyderen med det formål, at abonnenten kan begrænse børn og unges forbrug af mobiltelefoner, er dette mere tvivlsomt. Afhængig af over hvor lang tid, merforbruget er oparbejdet, og af teleudbyderens markedsføring kan resultatet blive, at abonnenten berettiget kan gå ud fra, at det aftalte/forudbetalte maksimum ikke kan overskrides, hvorfor teleselskabet ikke blot kan bryde en sådan aftale (f.eks. ved at oplyse den kode, der kan åbne for maksimumsgrænsen til et barn, der ringer til teleselskabet) og derefter afkræve abonnenten for merforbruget.

Der er i telelovgivningen kun krav om, at spærring for brugen af overtakserede SMS/MMS'er kan ske ved at spærre helt for telefonen, men dette er ikke nogen tilfredsstillende løsning for en del forbrugere (og erhvervsdrivende). Som det er nu, må kunden vælge mellem et abonnement uden mulighed for at anvende de overtakserede SMS/MMS'er og et abonnement, hvor der er mulighed herfor, men hvor denne mulighed kun kan begrænses ved en saldomaksimumsaftale. Det ville være hensigtsmæssigt, at man kunne have et abonnement, der indebar muligheden for både at kunne anvende de overtakserede SMS/MMS ydelser og forhindre andre i at bruge dem - f. es. børn og uberettigede tredjemænd.

Der skal ud over mulighed for spærring tilbydes en løbende udsvingskontrol, jf. udbudsbekendtgørelsens $\S 15$, stk. 1, jf. $\S 23$, således at forbrugeren modtager information om, at forbruget f.eks. i en periode er $100 \%$ større end det gennemsnitlige forbrug. Dette kan hjælpe til at opdage et eventuelt overforbrug fra en mindreårigs side.

\subsubsection{Opfylder dansk lovregulering forbrugerens behov for beskyttelse}

Sammenfattende kan det siges, at forbrugerens behov for beskyttelse i det store og hele mødes af lovgivningen, men der er enkelte punkter, hvor dette ikke er tilfældet:

Der mangler en afklaring af, hvilke regler, forbrugeren hæfter efter ved tredjemands misbrug af mobiltelefonen som betalingsmiddel.

Der mangler en afklaring af konsekvensen af, at udbyderen af et betalingssystem ikke overholder aftaler om saldokontrol/saldomaksimum, uanset at dette er mange forældres mulighed for at begrænse børn og unges mobiltelefonforbrug.

Såfremt Danmark fastholder den fortolkning af direktiv om fjernsalg artikel 5, stk. 2, der er fastlagt i forbrugeraftalelovens $\S 11$, stk. 5, findes forbrugerens behov for oplys- 
ninger mødt af den danske lovgivning. Såfremt denne fortolkning ændres i overensstemmelse med det, der gælder i f.eks. Sverige, kan der opstå et alvorligt hul i forbrugerbeskyttelsen på dette punkt i takt med, at betaling via SMS/MMS udvikles og udbredes, og det drejer sig om stigende beløb, der handles for over telefonen.

Der bør overvejes et selvstændigt ansvar for teleselskaberne i forhold til forbrugerne for tjenesteudbydere, der i grov og gentagen grad misligholder aftaler med forbrugerne, overtræder regler for god markedsføringsskik eller på anden måde udviser adfærd, der er stærkt belastende for forbrugerne.

Særligt i relation til børn og unge er der behov for beskyttelse mod vildledning f.eks. i forhold til pris og egenskaber ved ydelsen, og mod indholdet af de udbudte ydelser. Markedsføringsloven må dog give den fornødne mulighed for at opstille relevante krav til reklamemateriale, oplysninger og ydelsernes indhold. Beskyttelse af børn og unge mod at anvende store beløb på overtakserede SMS/MMS'er, må administreres af forældrene således, at børn ikke får abonnement med denne mulighed, eller ved hjælp af anvendelse af aftaler om saldomaksimum. Aggressiv markedsføring rettet mod børn og unge kan reguleres efter reglen i markedsføringslovens $\S 1$ om god markedsføringsskik.

Der savnes en pligt til at tilbyde særskilt spærring/pinkode for anvendelsen af overtakserede SMS/MMS'er. Udviklingen af mobiltelefonen som betalingsmiddel kan ikke i sin nuværende form antages at være et sikkert betalingsmiddel, Som forholdene er nu, må man enten vælge et abonnement uden mulighed for at anvende overtakserede SMS/MMS'er, eller risikere, at børn eller en uberettiget tredjemand kan misbruge telefonen til betalinger.

\subsubsection{Giver dansk lovregulering anledning til barrierer i udviklingen af mikro- betalingssystemer?}

Lovgivningen på området er overordentlig kompliceret og uoverskuelig, hvilket i sig selv må antages at udgøre et problem for de erhvervsdrivende. Dette problem kan dog i nogen grad afhjælpes ved udfærdigelse af vejledninger til de erhvervsdrivende.

Den erhvervsdrivende leverandør af varer eller tjenesteydelser vil - med visse undtagelser, jf. ovenfor - være forpligtet til: At udvikle sikre, overskuelige og velfungerende betalingssystemer (eller kun at tilslutte sig sådanne eksisterende systemer), at give oplysninger inden aftalens indgåelse om sig selv og den omhandlede vare/tjenesteydelse og dens pris, egenskaber og leverings- og betalingsforpligtelser m.v., herunder oplysning om en eventuel fortrydelsesret for forbrugeren, at give disse oplysninger læsbart på papir eller andet varigt medium, senest når aftalen er indgået, at give ordrebekræftelse og kvittering uden unødig forsinkelse, samt at respektere og effektuere en eventuel fortrydelsesret.

Den erhvervsdrivende, der er ansvarlig for betalingssystemet i forhold til forbrugeren, vil være forpligtet til: At sikre, at betalingsmidlet er sikkert og velfungerende, at afgive oplysninger om betalingssystemet, inden aftalen indgås, herunder oplysninger om systemets anvendelsesmuligheder og risici, at afgive kvittering efter hver transaktion, medmindre brugeren på anden måde har let adgang til oplysninger om, hvorvidt og hvornår den pågældende transaktion er gennemført, at give oplysninger om løbende transaktioner (kontoopgørelser) med fornøden mulighed for forbrugeren for at føre kontrol med rigtigheden af posteringerne, at hæfte i visse tilfælde af tredjemands misbrug 
over for forbrugeren samt at iagttage god skik vedrørende behandling og opbevaring af personoplysninger.

Mange af disse forpligtelser "giver sig selv", når den erhvervsdrivende udfører almindelig, god markedsføringsmæssig adfærd, men enkelte af kravene må antages med den nuværende teknologi i en vis grad at udgøre en barriere for udviklingen af betalingssystemer. Dette gælder i særlig grad kravet i forbrugeraftalelovens $\S 11 \mathrm{a} \mathrm{om}$, at oplysningerne skal afgives læsbart på papir eller på et andet varigt medium, som forbrugeren råder over og har adgang til. Der kan dog formentlig findes en smidig ordning på dette problem, således at forbrugeren umiddelbart får de for aftalen umiddelbart nødvendige oplysninger, og resten af oplysningerne lagres på en internetside, jfr. ovenfor undr afsnit 8.1.3.3.

Det må bemærkes, at flere af de teleselskaber, der har søgt om dispensation fra betalingsmiddelloven selv angiver, at de allerede opfylder lovgivningens krav.

Kravene $\mathrm{i}$ forbrugeraftaleloven og lov om e-handel er i stort omfang direktivbaserende og kan dermed ikke fraviges i national ret.

Såfremt man ønsker at lempe reglerne for oplysningernes afgivelse, skal der foretages en afvejning af behovet for/ønsket om dette og af beskyttelsen af forbrugeren. I denne afvejning bør det erindres, at mange mikroaftaler retter sig markedsføringsmæssigt mod og indgås af ganske unge mennesker. Man kunne derfor overveje at sætte grænsen for de udformede undtagelsesregler ret lavt pr. ydelse/pr. kunde/pr. dag.

\subsection{Norge}

\subsubsection{Oversigt.}

Der findes heller ikke i Norge nogen lovgivning, der specifikt regulerer mikroaftaler og mikrobetalinger, men retsstillingen på dette område har også her karakter af en række love, der gælder generelt for særlige forhold og områder. De væsentligste offentligretlige regler findes i markedsføringsloven, personoplysningsloven og lov om epengeforetak. Finansavtaleloven gælder ikke direkte for elektroniske pengeaftaler, men principperne $\mathrm{i}$ finansavtalelovens regler kan muligvis blive retningsgivende for indholdet i vilkår for tjenester fra udbyderen af elektroniske penge. Dette gælder bl.a. vedrørende oplysningspligt og forbrugerens hæftelse for andres misbrug af betalingsmidlet.

De privatretlige regler, der har mest relevans for reguleringen af mikroaftaler og mikrobetalinger, findes i e-handelsloven, angrerettloven, kreditkjøpsloven, avtaleloven og vergemålsloven og forbrukerkjøpsloven.

Der er herud over udarbejdet brancheaftale for markedsføring og salg af mobile indholdstjenester. Brancheaftalen er lavet i samarbejde mellem Teleforum, som er en brancheorganisation for leverandører af mobile indholdstjenester og Forbrukerombudet. Reglerne i denne aftale har til formål at sikre forbrugerinteresser og bidrage til en sund udvikling af markedet for mobile indholdstjenester. Reglerne giver ikke en udtømmende regulering af de mobile indholdstjenester, og de kan ikke regnes på linje med retningslinjer eller lignende fra Forbrukerombudet. 


\subsubsection{Offentligretlig regulering}

Markedsføringsloven er også i Norge den lov, der bredt og generelt regulerer markedsføringsforhold. Markedsføringslovens $\S 1$, stk. 1, indeholder en generalklausul, der lyder: "I næringsvirksomhet må det ikke foretas handling som strider mot god forretningsskikk næringsdrivende imellom eller er urimelig i forhold til forbrukere eller som for øvrig strider mot god markedsføringsskikk".

Ved vurderingen af, om generalklausulen er overtrådt, kan der bl.a. lægges vægt på, om reklamen på grund af udformning, formål, omfang eller andre virkemidler fremstår som særlig påtrængende, jf. § 1, stk. 3, og al markedsføring skal udformes og præsenteres på en sådan måde, at den tydeligt fremstår som markedsføring, jf. § 1, stk. 4.

Markedsføringsloven indeholder i $\S 2$ forbud mod vildledende forretningsmetoder, hvorefter det er forbudt at anvende urigtige eller af anden grund vildledende fremstillinger eller fremgangsmåder.

Både generalklausulen og forbudet mod vildledning er relevante i den retlige regulering af mikrobetalinger og mikroaftaler både $\mathrm{i}$ forhold til udbyderen af betalingsmidler og af vare og tjenesteydelser. Disse generelle regler suppleres af markedsføringslovens $\S 3$, hvorefter det er forbudt i næringsvirksomhed at anvende fremstilling, som er egnet til at påvirke efterspørgslen efter eller udbudet af varer, tjenester eller andre ydelser, når fremstillingen ikke giver forsvarlig eller tilstrækkelig vejledning eller trækker uvedkommende forhold ind og derfor må anses for at være urimelig. Det samme gælder efter $\S 3$, stk. 2, enhver anden fremgangsmåde, dersom den udnytter forbrugernes mangelfulde erfaring eller kundskaber og derfor må anses for at være urimelig.

Disse tre generelt gældende markedsføringsregler giver også i Norge mulighed for en virksom, effektivt og fleksibel regulering af forholdene omkring mikroaftaler og mikrobetalinger, såfremt der er ressourcer til at følge op på eventuelle overtrædelser. Hertil kommer markedsføringslovens specialregler, hvoraf bl.a. kan nævnes forbudet i $\S 2$ a mod at kræve betaling for varer, tjenesteydelser eller andre ydelser uden forudgående aftale samt mod uanmodet levering af varer, tjenesteydelser eller andre ydelser. Denne regel må også i Norge kunne anvendes til støtte for kravet om, at leverandører af SMStjenester skal have et klart aftalegrundlag for at udvide et almindeligt telefonabonnement til også at omfatte funktioner, hvorefter telefonen gøres til et betalingsmiddel via brugen af overtakserede SMS/MMS'er.

Det er i medfør af markedsføringslovens $\S 2 \mathrm{~b}$ forbudt i næringsvirksomhed uden modtagerens forudgående samtykke at rette markedsføringshenvendelser til forbrugeren ved hjælp af telekommunikationsmetoder, som tillader individuel kommunikation, som f.eks. elektronisk post, tekstbeskeder til mobiltelefonen, telefax eller talemaskiner (automatiseret opringningssystemer).

Kravet om forhåndssamtykke gælder dog ikke for markedsføring, hvor forbrugeren kontaktes mundtligt ved hjælp af telefon. Her gælder der imidlertid andre regler, der regulerer aftaler indgået ved telefonsalg, jf. angrerettlovens regler om oplysningspligt og fortrydelsesret, jf. angrerettlovens $\S \S 7,9$ og 4 .

Markedsføringslovens $\S 9$ a om urimelige aftalevilkår giver mulighed for offentligretligt at skride ind over for urimelige aftalevilkår, idet vilkår, der anvendes eller tilsigtes anvendt $\mathrm{i}$ erhvervsvirksomhed over for forbrugeren kan forbydes, når de findes urimelige over for forbrugerne, og det findes, at forbud tilsiges af almene hensyn. Dette giver en 
god mulighed for samspil med den privatretlige regulering i medfør af aftalelovens $\S \S$ 36-37. Se nærmere herom nedenfor i afsnit 8.2.3.

Lov om behandling av personopplysninger (personopplysningsloven) har til formål at beskytte den enkelte mod, at privatlivet bliver krænket gennem behandling af personoplysninger. Loven gælder bl.a. for behandling af personoplysninger, som helt eller delvis sker med elektroniske hjælpemidler og omfatter dermed de oplysninger, der kan indsamles og behandles i sammenhæng med mikrobetalinger.

Lovens $\S 8$ bestemmer, at personoplysninger kun kan behandles, dersom den registrerede har samtykket, eller det er fastsat i lov, at der er adgang til en sådan behandling, eller at behandlingen er nødvendig for at opfylde en aftale med den registrerede eller for at udføre gøremål efter den registreredes ønske, før en aftale indgås, at den behandlingsansvarlige skal kunne opfylde en retslig forpligtelse, --- at den behandlingsansvarlige eller tredjemand som oplysningerne udleveres til kan varetage en berettiget interesse og hensynet til den registrerede ikke overstiger denne interesse. Registrering af personfølsomme oplysninger er i medfør af $\S 9$ undergivet yderligere begrænsninger.

Brug af personnummer og andre entydige identifikationsmidler må kun benyttes i databehandlingen, når der er sagligt behov for en sikker identifikation, og anvendelsen er nødvendig for at opnå dette, jf. personopplysningslovens $\S 12$.

Den databehandlingsansvarlige og databehandleren skal sørge for tilfredsstillende informationssikkerhed med hensyn til fortrolighed, integritet og tilgængelighed ved behandling af personoplysninger, jf. lovens $\S 13$.

Enhver har krav på at få oplyst bl.a., hvilke typer registreringer der foretages, hvem den databehandlingsansvarlige er, samt hvilke oplysninger, der er registreret om vedkommende selv, jf. $§ 18$.

Lov om personoplysninger indeholder herudover en lang række krav og regler, der regulerer behandling og videregivelse af personoplysninger. Af særlig interesse kan nævnes $\S 21$ om informationspligt ved brug af personprofiler og $\S 26$ med ret til at reservere sig mod direkte markedsføring. En nærmere gennemgang vil dog være for vidtgående i denne sammenhæng.

Lov om e-pengeforetak gælder erhvervsdrivende, som udsteder betalingsmidler i form af elektroniske penge med undtagelse af banker og kreditinstitutioner. Ved elektroniske penge forstås en pengeværdi repræsenteret ved en (forudbetalt) fordring på udstederen, som er lagret på et elektronisk medium, er udstedt efter modtagelse af midler og er anerkendt som betalingsmiddel af andre erhvervsdrivende end udstederen.

Elektroniske betalingsmidler, som er forudbetalt for et beløb, der ikke overstiger 150 euro, kan under visse betingelser undtages helt eller delvist fra lovens regler.

Ihændehaveren af elektroniske penge kan i gyldighedsperioden kræve, at udstederen indløser de elektroniske penge til pålydende værdi i kontanter eller ved overførsel til en konto uden andre omkostninger end de, som er strengt nødvendige for at udføre denne transaktion, jf. § 1-6. Det kan dog aftales, at der fastsættes et mindstebeløb for indløsning, som ikke kan overstige $50 \mathrm{kr}$.

Lov om visse sider av elektronisk handel og andre informationssamfundstjenester (lov om e-handel) implementerer EU's direktiv om e-handel og indeholder regler, der også vil gælde for mikrobetalinger og mikroaftaler, idet loven gælder for elektronisk handel og andre informationssamfundstjenester. 
Tjenesteudbyderen skal ved udøvelse af sin virksomhed altid give information om sin virksomhed, jf. lovens $\S 8$. Der skal således oplyses navn, adresse, mailadresse og andre oplysninger, der gør det muligt at komme i direkte forbindelse med ham, jf. ehandelslovens $\S 8$, stk. 1 . Herudover skal tjenesteudbyderen give oplysning om diverse registre og godkendelser. Informationerne skal gøres enkle og direkte tilgængelige for tjenestemodtagere og offentlige myndigheder.

Bestemmelsen om tjenesteyderens oplysningspligt om virksomheden gælder ikke for tjenesteydere, som kun tilbyder tjenester, som består i at overføre information over et elektronisk kommunikationssystem, men denne undtagelse gælder ikke ved de i denne rapport omfattede mikroaftaler, der vedrører salg af varer og tjenesteydelser til forbrugeren.

Ved elektronisk markedsføring skal det klart fremgå, hvem markedsføringen sker på vegne af, og hvis uanmodet markedsføring sendes ved hjælp af elektronisk post (e-mail og SMS/MMS), skal det fremgå, at posten indeholder markedsføringsmateriale, idet meddelelse om posten modtages. Hvis der oplyses priser, skal disse være totalpriser inklusive afgifter og leveringsomkostninger, når markedsføringen retter sig mod forbrugere, jf. e-handelslovens $\S 9$.

E-handelsloven indeholder herudover krav om oplysninger, der skal gives før elektronisk bestilling og ved ordrebekræftelse, men disse regler gennemgås sammen med de privatretlige regler under afsnit 8.2.3.2 og 8.2.3.3 om oplysningspligten før og efter aftalens indgåelse.

Forbrugerombudet har udstedt retningslinjer for markedsføring og handel på Internettet, der uddyber og specificerer de erhvervsdrivendes pligter og forbrugernes rettigheder i medfør af markedsføringsloven og den øvrige, relevante lovgivning. Der er heri ikke taget stilling til forbrugernes hæftelse ved tredjemands misbrug, men retningslinjerne oplyser, at der arbejdes på at udfærdige nye retningslinjer, efterhånden som betalingsmetoderne udvikler sig.

\subsubsection{Privatretlig regulering}

Den privatretlige lovgivning i Norge indeholder regler, der regulerer aftaleindgåelse og aftalevilkår, krav om, hvilke oplysninger der skal gives før, under og efter indgåelse af en aftale, og finansaftaleloven indeholder regler om hæftelse og erstatning i tilfælde af tredjemands uberettigede brug af betalingsmidler; som muligvis vil finde retningsgivende anvendelse på elektroniske betalingsmidler udstedt af andre, eksempelvis teleselskabernes overtakserede SMS/MMS'er, jf. nedenfor afsnit 8.2.3.5.

\subsubsection{Indgåelse af aftale}

Ved indgåelse af aftale om tilslutning til selve mikrobetalingssystemet gælder de generelle regler i lov om avslutning av avtaler, om fuldmagt og om ugyldige viljeserklæringer (avtaleloven). Særligt gælder lovens $\S 36$, hvorefter en aftale kan tilsidesættes helt eller delvist, hvis det vil virke urimeligt eller i strid med god forretningsskik at gøre den gældende. For vilkår, der ikke er individuelt forhandlet mellem en forbruger og en erhvervsdrivende gælder aftalelovens $\S 37$, der implementerer EU's direktiv om urimelige kontraktvilkår i forbrugeraftaler.

Børn og unge under 18 år er beskyttet af vergemålsloven, særligt $\S \S 1$ og 2 og kapitel 4, hvorefter hovedreglen også i norsk ret er, at umyndige ikke kan forpligte sig økonomisk, og at en erhvervsdrivende ikke kan fastholde en aftale, der indebærer gældspåtagelse med en umyndig. 
Forbrugerombudsmanden har fastlagt retningslinjer for markedsføring og aftalevilkår i forhold til børn og unge, og der arbejdes for tiden med et stort projekt om markedsføring og mindreårige, der yderligere skal klargøre problemerne og retsstillingen på dette område.

Der gælder formentlig i Norge samme retsstilling for mindreåriges hæftelse for gæld stiftet via telefonabonnement som i Danmark. (Se afsnit 6.8.1 og 8.1.3.1), således at den mindreårige som udgangspunkt kun skal betale for en eventuel gæld efter nyttereglen, hvis han overhovedet skal betale noget. Men da de erhvervsdrivende generelt sørger for at have en myndig kontraktsansvarlig, er denne beskyttelse af de mindreårige mod et (over-)forbrug af mikrobetalingsydelser flyttet over på forældrene, der eventuelt må sørge for, at den mindreårige ikke får adgang til et sådant forbrug. Dette kan gøres ved at vælge et abonnement uden mulighed for at anvende overtakserede SMS/MMS'er, men der er heller ikke i Norge mulighed for at vælge en type abonnement, hvor man har denne mulighed, men kan spærre for den/kun anvende dem med brug af kode.

Der er i den norske lovgivning endnu ikke nogen regel om, at forbrugerne skal kunne kræve saldokontrol, men det er i forslag til forskrift til lov om elektronisk kommunikasjon foreslået, at slutbruger selv skal kunne sætte et maksimum for sit forbrug.

\subsubsection{Oplysningspligten inden aftalen indgås}

Den erhvervsdrivendes oplysningspligt er en væsentlig forudsætning for, at forbrugeren kan få tilstrækkelig viden om, hvem han indgår aftalen med, hvilken ydelse, der købes, og prisen herfor, hvilke vilkår, der gælder for aftalen, hvor der kan klages ved manglende kontraktoverholdelse fra sælgerens side osv. Fastlæggelsen af, hvilke oplysninger, der skal gives og hvordan og hvornår dette skal ske, er derfor også en væsentlig del af de love, der regulerer mikroaftaleområdet. Dette gælder for e-handelsloven, angrerettloven og lov om kreditkøb m.m.

E-handelsloven indeholder en række offentligretlige regler om oplysningspligt i forbindelse med elektronisk markedsføring generelt og i forbindelse med konkret aftaleindgåelse i $\S \S 8-11$, medens $\S 12$ handler om ordrebekræftelse.

En tjenesteyder skal ved udøvelse af sin virksomhed i medfør af e-handelslovens $\S 8$ altid give information om navn, adresse, e-mailadresse og andre oplysninger, der gør det muligt at komme i direkte forbindelse med tjenesteyderen, og herudover skal han give oplysning om registre og godkendelser/diplomer/uddannelser, den erhvervsdrivende har, hvis sådanne er en betingelse for at udbyde den ydelse, som er omhandlet af aftalen. Oplysningerne skal gives klart og direkte tilgængeligt for tjenestemodtageren og offentlige myndigheder. Det skal ved markedsføringen via elektroniske medier som ovenfor nævnt altid fremgå, at der er tale om markedsføring, og det skal klart fremgå, hvem markedsføringen sker på vegne af.

Før elektronisk bestilling skal tjenesteyderen i medfør af e-handelslovens $\S 11$ på en klar, forståelig måde give tjenestemodtageren oplysning om relevante adfærdsregler, som tjenesteyderen følger, og hvor disse kan findes elektronisk, om de forskellige tekniske skridt, som er knyttet til aftaleindgåelsen, om en indgået aftale vil blive gemt af tjenesteyderen, og om den vil være tilgængelig for modparten, om de tekniske midler til at finde og rette indtastningsfejl før bestilling foretages, og om de sprog, aftalen kan indgås på.

Aftalevilkår, standardvilkår og generelle vilkår må gøres tilgængelige for tjenestemodtageren på en måde, der gør det muligt at lagre og gengive dem, jf. e-handelslovens $\S$ 11 , stk. 2. 
Tjenesteyderen skal tilrettelægge den elektroniske aftaleindgåelse på en måde, så indtastningsfejl på en enkel måde kan opdages og rettes, før aftalen indgås, jf. § 11, stk. 3. Denne regel gælder dog - ligesom kravet om oplysninger i $\S 11$, stk. 1 - ikke for aftaler, der udelukkende indgås ved elektronisk post eller tilsvarende individuel kommunikation, jf. $\S 11$, stk. 4. Der er dog kun indgået aftaler udelukkende ved brug af individuel kommunikation i ganske få tilfælde, da langt størstedelen af elektronisk indgåede aftaler sker på baggrund af den erhvervsdrivendes reklame m.v.

Angrerettloven fastlægger i $\S 7$ oplysningspligt før aftaleindgåelsen. $\S 7$, stk. 1, bestemmer således generelt, at forbrugeren, før der bliver indgået aftalen, skal modtage de oplysninger, som forbrugeren har grund til at regne med at få, herunder oplysninger, som forbrugeren har krav på at få efter anden lovgivning.

Forbrugeren har efter $\S 7$, stk. 2, som minimum krav på at få oplysninger om varens eller tjenestens vigtigste egenskaber, den samlede pris, forbrugeren skal betale inkl. afgifter og leveringsomkostninger med specifikation af de enkelte poster, fortrydelsesretten, de væsentligste aftalevilkår, sælgerens navn og adresse, tidsrummet for tilbudet eller prisens gyldighed, omkostningerne ved at bruge fjernkommunikationsmetoden, hvis ikke denne beregnes efter normaltakst samt hvilke sprog, informationerne er tilgængelige.

Oplysningerne skal gives på en klar og forståelig måde, som skal tilpasses det medium, der anvendes til aftalen, jf. $\S 7$, stk. 3. Markedsføringen skal tage særligt hensyn til behovet for beskyttelse af mindreårige. Hvis markedsføringen retter sig mod norske forbrugere eller er på norsk, skal oplysningerne gives på norsk.

Finansavtaleloven opstiller en række krav til at give skriftlige oplysninger før indgåelsen af en kontoaftale med en forbruger. Der skal bl.a. gives oplysninger om nominel årlig rente, omkostninger ved at etablere have eller afvikle kontoen, betalingsinstrumenter knyttet til den, ansvar og risiko ved brug af kontoen og for andres uretmæssige brug af den m.m.

Finansavtaleloven gælder kun direkte for aftaler, der indgås mellem et pengeinstitut og en kunde, og gælder ved mikrobetalinger derfor kun direkte i forhold til bankers, sparekassers og lignende pengeinstitutters mikrobetalingssystemer. Den antages dog at kunne have regeldannende og retningsgivende funktion i forhold til resten af finansaftalemarkedet.

Lov om kreditkjøp m.m. (kreditkøbsloven) gælder for kreditkøb og kontoaftaler, og vil gælde for mikrobetalingssystemer med tilknyttet kontokreditaftale. Kreditkøbsloven bestemmer i $\S 3$ a, at hvor loven kræver skriftlige oplysninger, er dette ikke til hinder for brug af elektronisk kommunikation, dersom køberen eller kontohaveren ønsker dette, ligesom aftaler, der skal indgås skriftligt efter loven, også under visse betingelser kan indgås ved brug af elektronisk kommunikation, jf. § 3 a, stk. 2.

Kreditkøbslovens $\S 5$ opregner kreditgiverens oplysningspligt, før der bliver indgået en kontokreditaftale. Disse oplysninger skal gives skriftligt og vedrører bl.a. kredittens maksimumsbeløb, årlige nominelle rente, effektiv rente, omkostninger m.v.

\subsubsection{Oplysninger m.v. efter aftaleindgåelse}

Når mikroaftalen er indgået, har forbrugeren krav på ordrebekræftelse og visse oplysninger om den indgåede aftale. 
E-handelslovens $\S 12$, stk. 2, bestemmer, at tjenesteyderen altid og uden ugrundet ophold skal sende en elektronisk bekræftelse, om al bestilling er modtaget, medmindre aftalen er indgået udelukkende ved elektronisk post eller tilsvarende individuel kommunikation. (Se overvejelserne om udelukkende brug af individuel kommunikation ovenfor under afsnit 8.1.3.3.)

E-handelslovens $\S 12$ stiller ikke specifikke krav til, hvad der skal stå i ordrebekræftelsen.

Angrerettloven kræver i $\S$, at forbrugeren i forbindelse med indgåelse af en aftale skal modtage en række oplysninger læsbart og lagret på papir eller andet varigt medium, som forbrugeren råder over.

De oplysninger, der skal gives, er en lang række af de samme oplysninger, som skulle gives før aftaleindgåelsen, jf. § 7, stk. 1, litra a-f, og herudover skal der gives oplysning om vilkår og fremgangsmåde samt virkning af fortrydelsesretten. Endelig skal der gives oplysning om eftersalgsservice, garanti m.m.

Ved tjenesteydelser skal oplysningerne gives snarest muligt efter aftaleindgåelsen, mens forbrugeren ved køb af varer skal have oplysningerne senest når de modtager varen.

Lovens $\S 9$, stk. 4, lyder

"Bestemmelsen her gjelder ikke for enkeltstående tjenester som ytes ved bruk av en fjernkommunikasjonsmetode og som faktureres av operatøren (for eksempel teletorgtjenester). Forbrukeren skal likevel kunne få opplyst den fysiske adressen til tjenesteyterens forretningssted der han eller hun kan inngi klager".

Dette er en implementering af fjernsalgsdirektivets artikel 5, stk. 2, 1. pkt., der på dansk lyder

"2. Stk. 1 finder ikke anvendelse på tjenesteydelser, hvor selve opfyldelsen sker ved anvendelse af fjernkommunikationsteknik, når disse tjenesteydelser leveres samlet på en gang, og hvor faktureringen foretages af formidleren af fjernkommunikationsteknikken".

og på engelsk lyder

"2. Paragraph 1 shall not? apply to services which are performed through the use of means of distance communication, where they are supplied on only one occasion and are invoiced by the operator of the means of distance communication".

Direktivets undtagelsesbestemmelse i artikel 5, stk. 2, gælder tilfælde, hvor det ikke er muligt at opfylde kravene til oplysninger og ordrebekræftelse på varigt medium, og den norske implementering heraf er næppe ganske i overensstemmelse hermed. Undtagelsen i direktivet skal efter dets indledende bemærkninger forstås meget snævert, idet forbrugeren uanset medium ikke bør opleve nogen begrænsning i den information, der gives (bemærkning 11). Direktivet lægger således ikke vægt på, at det er en enkeltstående tjenesteydelse, men at bestilling og levering sker på én gang, hvilket er noget andet. Forbrugerbeskyttelsen efter angrerettsloven bliver alvorligt forringet, hvis ikke denne bestemmelse fortolkes meget snævert, idet forbrugeren (særligt børn og unge) nemt kan foretage en serie enkeltstående mikroaftaler uden at tænke over konsekvenserne, og hvor fortrydelsesretten bliver illusorisk, fordi der ikke i forbindelse med den aktuelle beslutning gives oplysning om den i forbindelse med den endelige bestilling. Undtagelsen fortolkes dog ganske snævert, hvilket også er i overensstemmelse med princippet 
om, at undtagelser skal fortolkes indskrænkende. De oplysninger, der før aftalens indgåelse skal gives forbrugeren, som bl.a. indeholder fortrydelsesretten, skal ikke nødvendigvis gives på papir eller andet varigt medium, og særligt børn og unge kan have en tilbøjelighed til at se hurtigt hen over oplysninger, som de ikke lige skal bruge her og nu.

Den ordrebekræftelse, der skal fremsendes i medfør af e-handelslovens $\S 12$, stk. 2 bliver hermed forbrugerens eneste kontrolmulighed, når kontoudskriften kommer, måske uger senere, og der stilles ingen specifikke krav til dennes indhold og form.

Finansaftaleloven kræver, at en kontoaftale skal være skriftlig, jf. § 16. Aftalen skal bl.a. indeholde kontohaverens personnummer til identifikation af kontohaveren samt en lang række oplysninger til identifikation af kontoaftalen. Som ovenfor nævnt gælder finansaftalen ikke direkte mange aftaler om tilslutning til et mikrobetalingssystem, da disse indgås mellem en forbruger og en erhvervsdrivende, der ikke er et pengeinstitut, men mange af lovens regler er udtryk for almindelige obligationsretlige grundsætninger samt generelle forbrugerbeskyttende principper, hvorfor reglerne formentlig vil finde analog anvendelse på andre aftaler end dem, den umiddelbart omfatter. Dette vil også gælde for aftaler mellem en forbruger og en teleudbyder vedrørende anvendelse af overtakserede SMS/MMS'er.

\subsubsection{Fortrydelsesret}

Angrerettloven indeholder regler om fortrydelsesret ved aftaler indgået ved fjernsalg. Disse findes i kapitel 4, som også regulerer en stor del af mikroaftalerne.

Da området er i voldsom udvikling, og eksempelvis overtakserede SMS/MMS'er nu visse steder kan bruges til at betale for mad og drikkevarer, f.eks. på festivals, vil ikke alle mikroaftaler være fjernsalg, jf. definitionen heraf $i$ angrerettlovens $\S 6$, litra $b$, men er at betragte som salg uden for fast forretningssted. Loven undtager salg uden for fast forretningssted, når den samlede kontraktssum er under $300 \mathrm{kr}$., jf. $\S 2$, litra b.

Fortrydelsesretten gælder i 14 dage, jf. $\S 11$, men ikke for varer, der ikke kan leveres tilbage, eller som hurtigt forringes fysisk, jf. $\S 12$. Ved køb af varer regnes fristen fra, at modtagelse af de oplysninger, der skal gives efter lovens kapitel 3, er givet på foreskreven måde, jf. $\S 11$. Hvis oplysning ikke er givet om fortrydelsesretten, bliver denne forlænget til 1 år, jf. $\S 11$, sidste punktum.

Ved køb af tjenesteydelser er der ligeledes fortrydelsesret i 14 dage, men dette gælder ikke for spil (f.eks. tips) og lotterier samt enkeltstående tjenesteydelser, hvis sælgeren ved aftaleindgåelsen forpligter sig til at levere tjenester på et bestemt tidspunkt eller inden for et bestemt tidsrum. Dette vil medføre undtagelse fra fortrydelsesretten ved køb af billetter til transport, film, sportsbegivenheder m.m.

(For at være omfattet af undtagelsen i $\S 19$, litra b, må det kræves, at der er en sammenhæng mellem (begrundelse for) løftet om at levere tjenesteydelsen på et bestemt tidspunkt og indholdet af tjenesteydelsen, idet undtagelsen i modsat fald kan gøre fortrydelsesretten illusorisk, såfremt tjenesteyderen generelt fastsatte et bestemt tidspunkt for levering.)

Forbrugeren kan ved andet salg end telefonsalg (uopfordret henvendelse fra den erhvervsdrivende pr. telefon) give samtykke til, at tjenesteydelsen skal leveres før udløbet af fortrydelsesfristen med den virkning, at forbrugeren ved brug af fortrydelsesretten skal betale for den del af tjenesteydelsen, som er udført samt for medgåede materialer, jf. $\S 21$. 


\subsubsection{Haftelses- og ansvarsregler}

Lov om kreditkøb gælder bl.a. for kontokreditaftaler. Denne lovs $\S 8$ handler om forbrugerens indsigelser mod anden kredityder end sælgeren. Ved forbrugerkreditkøb kan køberen herefter gøre de samme indsigelser og pengekrav vedrørende købet galdende overfor anden kredityder, som han kunne overfor salgeren. Køberen skal give kredityderen besked snarest muligt, og kredityderen hæfter ikke for mere, end han har modtaget fra køberen i anledning af købet.

Finansavtaleloven indeholder i kapitel 5 regler om andres misbrug af konto og betalingsmidler. Ved tredjemands misbrug af en konto er udgangspunktet, at kontohaveren ikke er ansvarlig for andres uretmæssige brug, medmindre den, som har foretaget dispositionen, har legitimeret sig i overensstemmelse med reglerne i kontoaftalen, og misbruget har været muligt som følge af forsæt eller grov uagtsomhed fra kontohaveren eller nogen, som efter kontoaftalen har ret til at bruge kontoen, jf. finansaftalelovens $\S 34$, stk. 1. Ansvaret efter $\S 34$, stk. 1, er begrænset til kontoens disponible beløb på tidspunktet for misbruget. Hvis misbruget er sket i Norge ved brug af elektroniske betalingsmidler, kan ansvaret heller ikke overskride de belastningsgrænser, som gælder for den eller de brugsmåder, som er benyttet, jf. $\S 34$, stk. 2. Dette gælder dog ikke, såfremt kontohaveren har medvirket forsætligt til, at vedkommende har kunnet legitimere sig.

Misbrug af betalingskort er reguleret i finansaftalelovens $\S 35$, og her hæfter kontohaveren med indtil $800 \mathrm{kr}$. for tab, som skyldes andres uretmæssige brug af betalingskort, når tilhørende personlig kode eller andre lignende sikkerhedsprocedurer er brugt, jf. $\S$ 35, stk. 1.

Kontohaveren hæfter i medfør af $\S 35$, stk. 2, for op til $8.000 \mathrm{kr}$. for tab, der skyldes andres uretmæssige brug af betalingskort, hvis kontohaveren eller nogen, betalingskortet er overladt til, ved grov uagtsomhed har muliggjort misbruget, eller dette er muliggjort, fordi kontohaveren eller den, som betalingskortet er overladt til, har undladt at underrette pengeinstituttet snarest muligt efter at have fået kendskab til, at betalingskortet er kommet bort eller inden rimelig tid efter, at dette burde være opdaget.

Hvis misbrug af elektronisk betalingskort er sket i Norge, kan ansvaret i medfør af $\S 35$, stk. 2, ikke overskride de belastningsgrænser, som gælder for den eller de brugsmåder, som er benyttet.

Ansvaret for tredjemands misbrug kan lempes i medfør af finansaftaleloven, dersom måden, kontoen kan anvendes på, ikke er betryggende, eller dersom betalings- eller kontokortsystemet ikke opfylder forsvarlige standarder for identifikation, kontrol og varslingsrutiner, og den uretmæssige belastning eller misbruget har sammenhæng med dette. Kontohaverens ansvar kan også nedsættes, dersom manglende påpasselighed eller andre forhold på pengeinstituttets side har medvirket til, at den uretmæssige belastning eller misbruget kunne ske.

Kontohaverens ansvar kan også nedsættes, hvis en leverandør af varer eller tjenester, som har modtaget betalingen, forstod eller burde forstå, at brugen af betalingsmidlet var uretmæssig.

Finansaftaleloven og dens regler om begrænset hæftelse for tredjemands uretmæssige brug af betalingsmidler gælder som nævnt ikke direkte for andre aftaler end aftaler med pengeinstitutter, og det er uafklaret i norsk retspraksis, i hvilket omfang disse regler vil finde analog anvendelse, f.eks. på teleselskabernes aftaler om brugen af mobiltelefoner som betalingsmiddel. 


\subsubsection{Saldokontrol}

Der er ikke i norsk lovgivning noget krav om, at forbrugerne skal tilbydes kontokontrol, men i forslag til forskrift til lov om elektronisk kommunikation $\S 5-7$ er det foreslået, at slutbruger selv skal kunne sætte en øvre grænse for forbruget (af trafikomkostninger). Såfremt denne kontrolmulighed ikke kommer til at omfatte også de beløb, der kommer fra overtakserede SMS/MMS ydelser, må der være et behov for, at der indføres en sådan regel.

\subsubsection{Opfylder norsk lovregulering forbrugernes behov for beskyttelse?}

Generelt kan det siges, at forbrugernes beskyttelse i forbindelse med mikroaftaler og mikrobetalinger efter norsk lovregulering har et relativt højt niveau, men at der er visse væsentlige huller i beskyttelsen.

Et ganske alvorligt hul i forbrugernes beskyttelse er de manglende klare regler for hæftelse for tredjemands uberettigede brug af konto og af betalingsmidler for så vidt angår andre aftaler end pengeinstitutters aftaler med forbrugeren. Forbrugeren har behov for beskyttelse også ved misbrug af mobiltelefoner og andre mikrobetalingsmidler, som med den udvikling, der er i gang, vil åbne for store muligheder for misbrug. Hvis finansavtaleloven finder anvendelse herpå, giver denne en rimelig beskyttelse af forbrugeren.

Såfremt der med forskrift til lov om elektronisk kommunikation kommer regler om saldokontrol, vil dette være en styrkelse af forbrugerens beskyttelse. Denne saldokontrol bør dog omfatte forbrug via overtakserede SMS/MMS beskeder.

Et sådant "hul" udgør også angrerettlovens $\S 9$, stk. 4, hvorefter forbrugeren ved enkeltstående tjenesteydelser ikke har krav på ordrebekræftelse med tilhørende oplysninger om ydelsens pris, sælgerens navn og adresse, fortrydelsesret m.v. Da i hvert fald en meget stor del af de overtakserede SMS/MMS'er vil falde ind under denne undtagelsesbestemmelse, vil det være vanskeligt for forbrugeren at foretage en løbende kontrol af sine bestillinger og sit forbrug. Dette rammer ikke mindst børn og unge og de voksne, der har det økonomiske ansvar for deres aftaler.

Størrelsen og alvoren af dette "hul" hænger i nogen grad sammen med muligheden for at spærre for visse former for brug af en mobiltelefon. Hvis der kan spærres for anvendelsen af overtakserede SMS/MMS uden at spærre for telefonens funktion som taletelefon og almindelig SMS/MMS telefon, vil der her kunne etableres en beskyttelse af mindreårige imod risikoen for at bruge større beløb på køb af vittigheder, ringetoner, spil til telefonen, horoskoper m.v.

Det bør muligvis også i Norge overvejes at indføre et selvstændigt ansvar for teleselskaberne $\mathrm{i}$ forhold til forbrugerne for tjenesteudbydere, der i grov og gentagen grad misligholder aftaler med forbrugerne, overtræder regler for god markedsføringsskik eller på anden måde udviser adfærd, der er stærkt belastende for forbrugerne.

Det kunne være ønskeligt, om brugen af telefonen som betalingsmiddel kun kunne ske efter åbning af denne funktion med en særlig kode. Dette ville sikre mod uberettiget tredjemands misbrug af en fundet eller stjålet mobiltelefon i dens funktion som bærer af et betalingsmiddel. 


\subsubsection{Giver norsk lovregulering anledning til barrierer i udviklingen af mikrobe- talingssystemer?}

De norske erhvervsdrivende har ikke i samme grad som de danske en kompliceret og uoverskuelig lovgivning at orientere sig i, men der er dog en række krav, der skal opfyldes, jf. ovenfor. Udarbejdelse af vejledninger og retningslinjer til de erhvervsdrivende ville muligvis være en service, som kunne komme såvel de erhvervsdrivende som forbrugerne til gode.

\subsection{Sverige}

\subsubsection{Oversigt}

Der gælder også i Sverige en række love og andre regler, der regulerer de retslige forhold vedrørende mikrobetalinger og mikroaftaler.

De væsentligste love af relevans for denne rapports fokusområde er for de offentligretlige loves vedkommende marknadsföringslagen (markedsføringsloven), lagen om elektronisk handel och andra informationssamhållets tjänster (e-handelsloven), personuppgiftslagen (lov om personoplysninger), lag om utgivning av elektroniska pengar og lag om elektronisk kommunikation.

Den privatretlige regulering udgøres primært af lag om avtalsvillkor i konsumentförhållden (forbrugeraftaleloven) og lag om avtal och andra rättshandlinger på förmögenhetsrättens område (aftaleloven), lag om konsumentskydd vid distansavtal och hemförsäljningsavtal (lov om distanceaftaler), föräldrabalk (myndighedsloven) og konsumentkreditlag (lov om forbrugerkreditaftaler). Den generelt gældende konsumentköplag (lov om forbrugerkøb) gælder også for de varer, der bliver købt via mikroaftaler, men da denne lov ikke vedrører nogen specielt problemstilling for varer købt ved mikroaftaler, inddrages den ikke yderligere. Ud over disse regler findes der regler i telelovgivningen, der regulerer visse forhold vedrørende telefonsystemer, der har relevans for betaling via SMS/MMS.

I Sverige findes der her udover et sæt etiske regler udarbejdet af Etiska Rådet för Betalteletjänster, som er en uafhængig organisation. Dette regelsæt indeholder bl.a. anvisninger for markedsføringen af betalingsteletjenester og anvisninger for indholdet på betalningsteletjenesterne. En konsekvens af overtrædelse af disse etiske regler er, at teleudbyderen ved grov overtrædelse fra tjenesteleverandørens side, kan blive forpligtet til at opsige aftalen om at udbyde dennes ydelser. Det er det Etiske Råd, der efter en vurdering af forholdene anbefaler, at abonnementsaftalen siges op, og teleoperatørerne har hidtil altid fulgt Rådets anbefalinger.

\subsubsection{Offentligretlig regulering}

Den vigtigste offentligretlige, generelle lovgivning, der regulerer markedsføringen af såvel den aftale, der knytter forbrugeren til selve mikrobetalingsmidlet og den enkelte mikrokøbsaftale, er markedsføringsloven. Markedsføringslovens $\S 4$ indeholder generalklausulen, hvorefter markedsføring skal stemme overens med god markedsføringsskik og også i øvrigt være tilbørlig over for forbrugere og erhvervsdrivende. 
Ved markedsføring skal den erhvervsdrivende i medfør af $\S 4$, stk. 2, give sådan information, som er af særlig betydning for forbrugeren. Al markedsføring skal udformes og præsenteres på en måde, så det tydeligt fremgår, at der er tale om markedsføring, ligesom det tydeligt skal fremgå, hvem der er ansvarlig for markedsføringen, jf. lovens $\S 5$.

Markedsføringslovens $§ 6-8$ regulerer vildledende reklame, hvorefter erhvervsdrivende ikke må anvende angivelser eller fremstillinger, som er vildledende, særligt vedrørende produktets art, mængde, pris, kvalitet m.v. Efterligninger, som er vildledende på grund af risiko for forveksling med andre erhvervsdrivendes produkter, er omfattet af forbudet mod vildledning i $\S 6$, og sammenlignende reklamer er reguleret i $\S 7$.

Det er også i Sverige forbudt at levere produkter til nogen, som ikke udtrykkeligt har bestilt dem, og på denne måde vildleder modtageren om dennes pligt til at betale, jf. markedsføringslovens $\S 12$.

Lov om personoplysninger har til formål at beskytte mennesker mod, at deres personlige integritet krænkes gennem helt eller delvist automatiseret behandling af personoplysninger, jf. lovens $\S \S 1$ og 5. Loven regulerer nøje, hvilke personoplysninger der må indsamles, gemmes, behandles og videregives, og på hvilken måde disse oplysninger kan samles og behandles m.v. Personoplysninger må efter $\S 10$ kun behandles, når den registrerede har givet sit samtykke, eller hvis behandlingen er nødvendig for, at en aftale med den registrerede kan opfyldes, at den, der registreres, kan opfylde sine forpligtelser, eller for at tilgodese et formål, som vedrører den oplysningsansvarliges eller en tredjemand, til hvem oplysningerne videregives, interesse. Hensynet til denne interesse skal veje tungere end den registreredes interesse i beskyttelse mod krænkelse af den personlige integritet, jf. $\S 10$.

Den registrerede kan give samtykke til indsamling og anvendelse af personoplysninger, jf. § 13. Personoplysningslovens område omfatter også mikroaftalekunder, og de erhvervsdrivende skal derfor også i sådanne relationer iagttage lovens krav og forbud.

E-handelsloven har i $\S \S 8-14$ en række regler om den erhvervsdrivendes oplysningspligt ved elektronisk handel. Disse regler vedrører oplysningspligten ved markedsføring af informationssamfundstjenester, ved aftaleindgåelse og ved ordrebekræftelse. Da disse oplysningskrav skal ses i nær sammenhæng med de privatretlige reglers krav om oplysninger i relation til disse situationer, vil e-handelsloven blive beskrevet sammen med de privatretlige regler i afsnit 8.3.3.

Loven om aftalevilkår i forbrugerforhold har en række offentligretlige, markedsretlige bestemmelser i $\S \S 3-9$. Disse regler medfører, at Marknadsdomstolen kan forbyde en erhvervsdrivende for fremtiden at anvende aftalevilkår, der findes urimelige i forhold til forbrugere, hvis dette er påkrævet ud fra en almindelig vurdering eller på anden måde er i forbrugernes eller konkurrenternes interesse, jf. lovens $\S 3$.

Lag om utgivning av elektroniska pengar indeholder regulering af udbud af elektroniske penge. Loven er primært af offentligretligt indhold til regulering af udbydernes forhold. Dog indeholder kapitel $4, \S 3$ et krav om, at udgiveren skal indløse restbeløb i sedler og mønter eller ved overførsel til konto, hvis ihændehaveren begærer dette indenfor den aftalte gyldighedsperiode. Ved indløsning må udbyderen alene tage et gebyr, der modsvares af den omkostning, som har været absolut nødvendig for at gennemføre transaktionen. Der kan aftales et mindstebeløb for indfrielse. Dette beløb kan dom ikke overstige 10 euro. 
Lag om elektronisk kommunikation regulerer visse forhold vedrørende bl.a. teletjenester. Denne lov, der trådte i kraft sommeren 2003, gælder også for mobiltelefoni.

\subsubsection{Privatretlig regulering}

\subsubsection{Indgåelse af aftale}

Forbrugernes indgåelse af aftaler om tilslutning til et mikrobetalingssystem og af den enkelte mikroaftale er omfattet af lov om aftalevilkår i forbrugerforhold, som bl.a. indeholder implementering af EU's direktiv om urimelige aftalevilkår i forbrugeraftaler. Herudover gælder også den "almindelige" aftalelov og de generelt gældende formueretlige principper om vedtagelse af aftalevilkår m.v.

Forbrugeraftalelovens $\S \S 10-12$ indeholder de civilretlige (privatretlige) bestemmelser vedrørende aftalevilkår $\mathrm{i}$ forbrugerforhold, hvor vilkåret ikke har været genstand for individuel forhandling. Sådanne aftalevilkår tolkes i tilfælde af uklarhed til forbrugerens fordel, jf. $\S 10$, og der henvises til $\S 11$ til, at den almindelige aftalelovs generalklausul i $\S 36$ finder anvendelse i forbrugerforhold dog således, at efterfølgende omstændigheder, der måtte have betydning for vurderingen af aftalens urimelighed, ikke skal tages i betragtning til skade for forbrugeren ved vurderingen af aftalen.

Ud over denne særlige anvendelse af aftalelovens $\S 36$ finder aftalelovens øvrige regler om retshandlers ugyldighed i lovens kapitel 3 også anvendelse på forbrugernes indgåelse af mikrobetalingsaftaler. Dette gælder både for så vidt angår tilslutningsaftalen til selve betalingsmidlet og den enkelte mikroaftale, men reglerne vil formentlig kun i meget særlige undtagelsestilfælde nå frem til anvendelse i retssystemet i forhold til de små mikroaftaler, da dette ville være "at skyde spurve med kanoner". Dette ændrer dog ikke på det forhold, at reglerne også gælder for aftaler om 2, 10 og $20 \mathrm{kr}$.

Ved indgåelse af aftale med mindreårige gælder, at umyndige under 18 år ikke med bindende virkning kan indgå aftale om køb eller bestilling af varer eller tjenesteydelser, som indebærer gældsforpligtelser, jf. föräldrabalk kapitel 9, § 1. Dette har bl.a. betydet, at Konsumentverket $\mathrm{i}$ en regeringsrapport af december 2002, s. 18, finder anledning til at påpege, at beskyttelse af den mindreårige bør styrkes bl.a. i form af pligt for den erhvervsdrivende til at oplyse om, at mindreårige som regel ikke kan indgå forpligtende aftale uden værgens godkendelse. Mindreårige betaler ind imellem for krav, som de ikke er forpligtet til, hvorved den lovmæssige beskyttelse af dem forspildes.

Da som nævnt ovenfor teleselskaberne sørger for at have en myndig kontraktspart, er beskyttelsesproblemet vedrørende de mindreåriges brug af mikrobetalinger og overtakserede SMS/MMS'er formentlig i praksis et andet, nemlig etablering af muligheden for, at den myndige kontraktsansvarlige kan overlade en mobiltelefon til en mindreårigs brug, således at denne kan telefonere og sende almindelige SMS'er, uden at man samtidig overlader den mindreårige mulighed for at forpligte den kontraktsansvarlige ved brug af telefonen som betalingsmiddel. Dette kræver mulighed for at kunne vælge abonnement uden betalingsfunktion tilknyttet (og det er ikke tilfredsstillende at henvise sådanne kunder til de dyre taletidskort), mulighed for at kunne spærre for denne funktion ved hjælp af en særlig kode og/eller mulighed for effektiv saldokontrol. Denne problemstilling bliver accentueret $\mathrm{i}$ takt med udviklingen af mobiltelefonen som betalingsmiddel. 


\subsubsection{Oplysningspligten inden aftalen indgås}

Oplysningspligten vedrørende mikroaftaler er i svensk ret fastslået i flere af de love, der regulerer området. Således findes der regler om den erhvervsdrivendes oplysninger til forbrugere i fjernsalgsloven og forbrugerkreditloven og hertil kommer de offentligretlige krav til den erhvervsdrivendes oplysninger, som findes i e-handelsloven.

Lov om e-handel gælder informationssamfundets tjenester, men hasardspil med penge som indsats er som i de øvrige, nordiske lande undtaget fra lovens område, jf. $\S 1$, stk. 2 , litra 6 .

Lovens $\S 8$ kræver, at den erhvervsdrivende (leverandøren) ved markedsføring skal give oplysning om sit navn, sin adresse i etableringsstaten og sin e-mailadresse samt eventuel organisationsnummer, registreringsnummer for merværdiskat og relevant tilsynsmyndighed. Herudover skal oplysning gives om faglige titler og tilknytning til faglige organisationer og de regler, der gælder for erhvervsvirksomheden og om, hvordan man kan få tilgang til dem.

Der er ikke krav om, at prisen på en vare eller tjenesteydelse skal oplyses ved enhver markedsføring, før aftale indgås, men hvis prisen oplyses, skal denne angives klart og utvetydigt. Hvis skat og leveringsomkostninger ikke er inkluderet i prisen, skal dette oplyses særskilt.

Den, der leverer informationssamfundstjenester, skal stille egnede og effektive tekniske hjælpemidler til rådighed for tjenestemodtageren, som gør det muligt at opdage og rette eventuelle indtastningsfejl, inden bestilling afgives, jf. e-handelslovens $\S 10$.

Leverandøren skal endelig på klar og utvetydig måde inden tjenestemodtageren afgiver bestilling, oplyse om følgende:

1) hjælpemidler til at finde og rette fejl og om de tekniske skridt, der skal til for at indgå en aftale,

2) hvilke sprog, aftalen kan indgås på,

3) om aftalen arkiveres, og om den holdes tilgængelig for tjenestemodtageren samt

4) de fag-etiske regler el.lign., som leverandøren har påtaget sig at følge, og muligheden for at få adgang til den på elektronisk vis.

E-handelsloven stiller ikke krav om, hvorledes oplysningerne skal gives, og ofte giver dette sig selv i og med, at oplysningerne gives på det medium, som markedsføringen i øvrigt sker på (Internet, TV m.v.). Oplysningerne kan gives på en internetside og i en email, men det er uklart, om det er nok at henvise til leverandørens hjemmeside. Der skal i henhold til $\S \S 8$ og 11 "gives information" og klart og tydeligt "informeres", og dette må kræve, at tjenestemodtageren har oplysningerne lige "ved hånden". E-handelslovens $\S 8$, stk. 2, kræver, at informationen skal findes tilgaengelig for tjenestemodtageren og myndigheder på en enkel, direkte og stadigvarende måde.

Lov om forbrugerbeskyttelse ved fjernsalg og salg uden for fast forretningssted regulerer bl.a. indgåelse af fjernsalgsaftaler. Loven omfatter ikke fjernsalgsaftaler, som indgås ved hjælp af vareautomater eller automatiseret forretningslokaler $(\S 3$, litra 3$)$, aftaler der indgås med en teleoperatør gennem anvendelse af en offentlig telefonautomat, eller som indgås ved en auktion, hvor budgivningen normalt ikke sker elektronisk ( $\$ 3$, litra 4 og 5).

Loven har en undtagelse for aftaler indgået uden for fast forretningssted, som overstiger $300 \mathrm{kr}$. ( $§ 4$, litra 1). Denne undtagelse gælder ikke for fjernsalgsaftaler, da direktivet om fjernsalg ikke åbner mulighed for en sådan undtagelse. 
Reglerne om oplysningspligt efter aftalens indgåelse (§ 6) og ordrebekræftelse ( $(11)$ (og om fortrydelsesret, jf. $\S \S 13-20$ ) gælder ikke ved fjernsalgsaftaler om salg af levnedsmidler eller andre varer til husholdningen, når varerne skal leveres til forbrugernes hjem eller arbejdsplads i et distributionssystem med fast udbringning, jf. lovens $\S 6$.

Oplysningspligten og fortrydelsesretten gælder heller ikke for fjernsalgsaftaler om indkvartering, transport, servering, catering, eller andre lignende tjenesteydelser eller vedrørende kulturbegivenheder, idrætsbegivenheder eller lignende fritidsaktiviteter, såfremt den erhvervsdrivende påtager sig at levere tjenesten på en bestemt dag eller i en bestemt periode (distanceaftalelovens $\S 7$ ).

Disse undtagelser fra lovens regler om oplysningspligt efter aftalens indgåelse/ordrebekræftelse og om fortrydelsesret vil kunne omfatte en del af de mikroaftaler, som er behandlet i denne rapport, da betaling af tog og busbilletter, is, mad og drikkevarer, biograf- og sportsbilletter er nogle af de områder, hvor mikrobetalingerne er under hastig udvikling.

For alle distanceaftaler gælder dog reglen i lovens $\S 9$, der kræver, at den erhvervsdrivende ved markedsføring med henblik på fjernsalg (dvs. inden aftalens indgåelse) skal give information om 1) sit navn og adresse, 2) varens/tjenesteydelsens væsentligste egenskaber, 3) varens/tjenesteydelsens pris inkl. skatter og afgifter, 4) eventuelle leveringsomkostninger, 5) betalings- og leveringsvilkår, 6) fortrydelsesretten, 7) omkostninger ved brugen af fjernkommunikationsmidler, hvis ikke denne omkostning er beregnet efter normaltakst, 8) den tid, tilbudet gælder og 9) aftalens korteste løbetid, hvis aftalen angår løbende leverancer af varer eller tjenesteydelser.

Ovennævnte information skal efter $\S 9$, stk. 2, gives i rimelig tid, inden aftalen indgås. Oplysningerne skal gives klart og forståeligt og med anvendelse af metoder, der er tilpasset det relevante fjernkommunikationsmiddel. Loven angiver ikke, hvorledes oplysningerne skal gives, men da det i en række af aftalerne vil blive de eneste oplysninger, forbrugeren får (nemlig i den gruppe aftaler, der er omfattet af undtagelsesbestemmelserne i $\S 7$ ), må det være et krav, at oplysningerne gives på en måde, hvor forbrugeren rent faktisk har let adgang til dem. Det vil således næppe ved salg af mikroaftaler via mobiltelefon være tilstrækkeligt blot at henvise til en internetadresse.

Den erhvervsdrivende skal tage særligt hensyn til behovet for beskyttelsen af mindreårige, jf. § 9, stk. 2, sidste punktum. Dette må betyde, at de reklamer, der f.eks. lanceres i blade med børn som målgruppe vedrørende køb af ringetoner, logoer, vitser m.v., bør udformes på en betydeligt mere klar og entydig måde, end visse af dem, der hidtil er set.

Hvis markedsføring sker pr. telefon, skal den erhvervsdrivende i begyndelsen af telefonsamtalen give forbrugeren oplysning om sin identitet og om hensigten med samtalen, jf. $\S 9$, stk. 3 .

Forbrugerkreditloven kræver i $\S 6$, at den erhvervsdrivende ved annoncering, skiltning og lignende markedsføring vedrørende kredit over $1.500 \mathrm{kr}$. skal give oplysning om den effektive rente for kreditten, medmindre der er tale om kortvarige kreditter, som skal tilbagebetales inden 3 måneder.

Inden en kreditaftale indgås, skal den erhvervsdrivende skriftligt give forbrugeren oplysningerne efter $\S 6$, men dette kan gøres elektronisk, jf. lovens $\S 9$, der kræver, at en kreditaftale skal indgås skriftligt og underskrives af forbrugeren personligt eller med den elektroniske signatur, som er indført i Sverige ved lov om kvalificerede elektroniske 
signaturer. Hvis kreditaftalen ikke er indgået skriftligt, er den kun gyldig for så vidt angår vilkår, der ikke er til ulempe for forbrugeren.

\subsubsection{Oplysninger m.v. efter aftaleindgåelsen}

Når aftalen om tilslutning til mikrobetalingsmidlet er indgået, har forbrugeren efter forbrugerkreditloven krav på at få en kopi af aftalen, jf. § 9, og derefter har forbrugeren krav på kontoudtog. Loven opstiller dog ikke krav om, hvor ofte kontoudtog skal gives.

E-handelslovens $\S 12$ kræver, at tjenesteleverandøren uden unødig forsinkelse ad elektronisk vej skal bekræfte modtagelsen af en bestilling, som er blevet afgivet elektronisk. $\S 12$ indeholder ikke krav til formen for ordrebekræftelsen, ud over at den skal være elektronisk. Selve ordrebekræftelsen må dermed kunne afgives som SMS-besked.

Aftalevilkårene (dvs. aftalen suppleret med leverandørens almindelige betingelser) skal gøres tilgængelige for tjenestemodtageren på en måde, som gør det muligt at gemme og genskabe den, jf. $\S 13$. Dette krav er næppe opfyldt ved afsendelse af en eller flere almindelige SMS'er, men en henvisning til en internetside til kunder, som den erhvervsdrivende ved har adgang til Internettet, vil efter omstændighederne kunne opfylde lovens krav.

Oplysningspligten efter $\S \S 10$ og 11 og kravet om elektroniske ordrebekræftelser gælder ikke for aftaler, der er indgået udelukkende gennem udveksling af e-mails el.lign. personlige meddelelser, jf. $\S 14$. Denne undtagelse vil dog kun forekomme i få situationer, da langt de fleste handler indgås på baggrund af reklamer og anden massekommunikation. Se nærmere herom i afsnit 8.1.3.3.

Loven om distanceaftaler opstiller detaljerede krav til information, som skal gives inden en aftale indgås, jf. $\S 9$ (se ovenfor afsnit 8.3.3.2). Når en distanceaftale er indgået, skal den erhvervsdrivende hurtigst muligt derefter give forbrugeren en ordrebekræftelse indeholdende den information, som kræves efter $\S 9$, stk. 1, litra 1-5 (den erhvervsdrivendes navn og adresse, varens/tjenestens pris og beskrivelsen af dens væsentligste egenskaber, leveringsomkostninger og måden, hvorpå aftalen skal betales og levering/opfyldelse skal ske). Ved aftale om varer skal disse oplysninger gives senest ved leveringen. Ved tjenesteydelser skal oplysningerne gives snarest muligt.

Regeringsrapporten: Distansavtalslagen - en utvårdering af december 2002 peger på, at begreberne vare/tjenesteydelse er uklart i forhold til digitale ydelser, hvilket får betydning bl.a. i forhold til reglerne om oplysningspligten og fortrydelsesretten. Denne udredning konkluderer, at området trænger til en nærmere belysning og analyse.

Oplysningerne skal gives på papir eller i anden læsbar og varig form, som er tilgængelig for forbrugeren, jf. $\S 10$, stk. 1, 3. pkt. Hvis den erhvervsdrivende allerede én gang har givet oplysningerne $i$ en sådan form, behøver han ikke afgive de samme oplysninger igen, medmindre dette er særligt krævet $i$ andre af lovens regler. Oplysningerne skal gives snarest muligt, og det er tilstrækkeligt, at oplysningerne gives ved hjælp af en email til forbrugeren, eller i visse tilfælde ved henvisning til en specielt indrettet hjemmeside, såfremt handelen foregår over Internettet.

Ved handel med mobiltelefon er problemstillingen også i Sverige uafklaret, idet almindelige SMS'er heller ikke her kan anses som "varigt medium". (Der henvises til diskussionen ovenfor i afsnit 8.1.3.3. ). Problemets omfang er dog mindre i Sverige end i Danmark, da man her har fastlagt undtagelsen i fjernsalgsdirektivets artikel 5, stk. 2 væsentligt bredere, idet man har fortolket artikel 5, stk. 2 som en regel, der gælder for 
enkeltstående leverancer. Langt størstedelen af mikroaftalerne angår enkeltstående leverancer: Ringetoner, spil til telefonen, logoer, betaling for drikkevarer, billetter osv. Man må derfor formentlig i Sverige have langt flere køb, der falder ind under det, der var tænkt som en snæver undtagelse i direktivet, end man har tilfælde, der falder ind under direktivets hovedregel. Se nærmere herom nedenfor.

Forbrugeren skal altid på papir eller i anden læsbar og varig form have oplysning om 1) fortrydelsesretten $\mathrm{i}$ henhold til loven om distanceaftaler samt navn og adresse på den, som fortrydelsesretten kan udøves overfor, 2) den fysiske adresse på den erhvervsdrivende, hvortil forbrugeren kan fremsætte sine eventuelle klager, 3) garantier og service og 4) vilkår for opsigelse af aftaler, der gælder indtil videre eller i længere tid end 1 år.

Fjernsalgsdirektivets artikel 5, stk. 2 er implementeret således, at hvis fjernaftalen gælder en tjeneste, hvis opfyldelse sker ved hjælp af et middel til fjernkommunikation, og tjenesten udføres "vid ett enda tillfälle" og faktureres af distributøren af kommunikationsmidlet, behøver distributøren kun at give adgang til den fysiske adresse, hvortil forbrugeren kan klage til den erhvervsdrivende, jf. § 10, stk. 3.

Dette fortolkes i svensk ret således, at $\S 10$, stk. 3, betyder, at der ikke er oplysningspligt efter $\S 10$, stk. 1 og 2, ved enkeltstående aftaler. Denne fortolkning må dog afgrænses meget snævert for at være i overensstemmelse med direktiv om e-handel artikel 5, stk. 2, der udgør en klar undtagelse til oplysningspligten i artikel 5, stk. 1, hvori der endog tales om, at forbrugeren altid under alle omstændigheder skal have oplysning m.v. og direktivets indledende bemærkninger - særligt i betragtning nr. 11 - hvorefter brugen af fjernkommunikationsmidler ikke må føre til en reduktion i oplysningerne til forbrugerne, som derfor skal have de foreskrevne oplysninger, uanset hvilke kommunikationsmidler der anvendes. Ved direktivets udarbejdelse var der lagt vægt på, at levering og bestilling sker samlet på en gang og ikke kan adskilles i flere tempi. Der nævntes herved som eksempel oplysningstjeneste, deltagelse i afstemninger eller konkurrencer $\mathrm{i}$ forbindelse med Tv-udsendelser o. lign. Da undtagelser skal fortolkes indskrænkende, og da en udvidelse af artikel 5, stk. 2, til at omfatte enkeltstående leveringer i princippet kunne komme til at omfatte langt hovedparten af alle distanceydelser og herunder også mikroaftaler, var dette næppe direktivets hensigt med undtagelsen. Den svenske fortolkning af denne undtagelse kan give anledning til en vis bekymring ikke mindst set $\mathrm{i}$ lyset af den udvikling, mikrobetalingerne via mobiltelefonen må forventes at befinde sig $i$.

Hvis undtagelsen om, at der ikke skal gives oplysninger ved enkeltstående leverancer tænkes igennem i forhold til den forventelige udvikling, kan følgende eksempel blive hverdag for forbrugeren af overtakserede SMS'er:

Forbrugeren ser en reklame for en ydelse, der kan erhverves via overtakserede SMS'er. I reklamen (i f.eks. et ugeblad, på en plakat, i en Tv-reklame eller andet) er oplyst leverandørens navn, varens/tjenesteydelsens pris og egenskaber osv. Der er jo ikke noget krav om, at de forudgående oplysninger skal gives på papir eller andet varigt medium. Forbrugeren sender en SMS til dette nummer og bestiller ydelsen (f.eks. et spil, en bog, en film, noget musik). Leverandøren sender en ordrebekræftelse i medfør af e-handelslovens $\S 12$, som ikke stiller krav om andet end en bekræftelse af, at man har modtaget kundens ordre. Når leveringen af bogen/filmen/musikken sker, har forbrugeren ikke længere oplysning om sin fortrydelsesret (hvis den var i reklamen) og heller ikke om ydelsens pris, hvad det præcist er, man har bestilt m.v. Når fakturaen over telefonregningen kommer, er forbrugerens eneste mulighed for at kontrollere rigtigheden heraf at forsøge at sammenligne sine afsendte bestillings-SMS'er med ordrebekræftelserne og kontoudtoget og så håbe på, at de indeholder oplysninger nok, og at bestillingerne ikke blot lyder: "AAGA dbabe" sendt til nummer 1231 og ordrebekræftelsen "Vi har modtaget din ordre i dag kl. 17.05, 
levering følger straks”. Det bliver vanskeligt for forbrugeren at kontrollere udskriftens rigtighed - for slet ikke at tale om at bevise, at der er fejl i den.

Da køb ved brug af overtakserede SMS/MMS er i rivende udvikling og planlægges at kunne omfatte også f.eks. film (også pornofilm), vil de beløb, der opkræves på denne måde, også blive større og større. Det er således ikke kun aftaler om 2, 5 og 10 kr., det handler om, og da det herudover ofte er børn og unge, der anvender denne betalingsform, er der et klart behov for, at forbrugeren netop i denne sammenhæng modtager alle relevante oplysninger på en måde, der gør det muligt at gemme og efterkontrollere dem.

Oplysningerne om fortrydelsesretten skal dog gives i umiddelbar sammenhæng med ordrebekræftelsen, såfremt den erhvervsdrivende ønsker, at forbrugeren skal have mulighed for at give samtykke til afbrydelse af fortrydelsesfristen, jf. lov om distanceaftaler $\S 14$, nr. 1 .

\subsubsection{Fortrydelsesret}

Lov om distanceaftaler giver i $\S 13$ forbrugeren ret til at fortryde en distanceaftale inden for 14 dage fra varens levering eller fra aftale om tjenesteydelsen indgåelse.

Også her ses vanskeligheden ved de digitale ydelser: Er bestilling af en digital bog eller film en vare eller en tjenesteydelse? Hvis det anses som en vare, kan forbrugeren nå at gøre sig et indtryk af bogen/filmen, før der tages stilling til fortrydelsesretten, men hermed kan leverandøren ikke sikre sig, at forbrugeren ikke har læst bogen/set filmen før fortrydelsesretten. Dette kan dog modvirkes ved at forsegle lyd og billedoptagelser elektronisk, jf. $\S 14$, nr. 4. Hvis bogen/filmen anses som en tjenesteydelse, begynder fortrydelsesretten at løbe straks, og forbrugeren modtager måske først ydelsen, når fortrydelsesfristen er udløbet - evt. efter at forbrugeren har givet samtykke til levering med afbrydelse af fortrydelsesretten til følge. Denne løsning er sikker for den erhvervsdrivende, men ikke ganske tilfredsstillende set fra et forbrugerbeskyttelsessynspunkt.

Ved distanceaftaler har forbrugeren ikke fortrydelsesret ved tjenesteydelser, hvoraf opfyldelse er påbegyndt med forbrugerens samtykke inden fortrydelsesrettens udløb, jf. $\S$ 14, litra 1. Der er ej heller fortrydelsesret ved varer, som på grund af deres beskaffenhed ikke kan tilbageleveres, eller som hurtigt forringes eller bliver for gammel ( $§ 14$, litra 3 ), ved forseglet lyd- eller billedoptagelse eller et forseglet dataprogram, hvor forseglingen er brudt ( $§ 14$, litra 4$)$ ved aviser og tidsskrifter eller ved væddemål (spil) og lotteritjenester.

Hertil kommer de aftaler, der som ovenfor nævnt ikke er omfattet af loven eller er omfattet af undtagelserne hertil i medfør af dens $\S \S 3-7$ (bl.a. indkvartering, transport m.v.) Se nærmere de relevante paragraffer og ovenfor afsnit 8.3.3.2).

En del af de aftaler, der indgås ved hjælp af mikroaftaler vil være omfattet af fortrydelsesretten, men også i Sverige vil det være muligt at levere tjenesteydelser til forbrugerne inden udløbet af de14 dage, såfremt den erhvervsdrivende sikrer sig forbrugernes samtykke, efter at aftalen om leveringen er indgået. Dette samtykke kan som tidligere nævnt også gives, selv om ydelsen købes via overtakserede SMS'er.

\subsubsection{Hæftelses- og ansvarsregler}

Lov om forbrugerkreditaftaler indeholder i $\S 34$ en regel om betalingsansvar ved mistet kontokort m.v. Denne regel bestemmer, at et aftalevilkår, der indebærer, at kontohaveren skal hæfte for et beløb, som er påført kontoen gennem en tredjemands uberettigede brug af kontokortet kun kan gøres gældende, hvis kontohaveren eller nogen anden, som i medfør af kontoaftalen er berettiget til at anvende kortet har 1) overladt kortet til nogen anden, 2) gennem grov uagtsomhed eller 3) på nogen anden måde har mistet besid- 
delsen af kortet og ikke snarest efter opdagelse heraf har anmeldt tabet til kreditgiveren. Kontohaveren hæfter kun for misbrug, der foretages efter meddelelse om, at kortet er bortkommet, hvis kontohaveren har udvist svig.

Denne regel kan muligvis finde analog anvendelse på misbrug foretaget via SIM-kortet til mobiltelefoner. Reglen har ikke nogen beløbsgrænse for kontohaverens hæftelse, og det vil blive afgørende for forbrugernes risiko, hvorledes $\S 34$, stk. 1, litra 2, om at miste kortet ved grov uagtsomhed og kravet om, at forbrugeren snarest efter opdagelsen skal anmelde tabet af kortet, vil blive fortolket. Når en åben mobiltelefon frit kan anvendes som betalingsmiddel uden yderligere brug af PIN-kode, medfører dette en væsentlig risiko for forbrugeren ved at bære sin mobiltelefon på sig eller $\mathrm{i}$ en håndtaske $\mathrm{i}$ åben tilstand. Overladelse af mobiltelefoner til børn og unge kan ved udviklingen af telefonerne som betalingsmiddel udvikle sig til at blive en betydelig økonomisk risikofaktor, såfremt der ikke udvikles bedre sikkerhedssystemer. For tiden har teleoperatører dog sat en overgrænse på $30 \mathrm{kr}$. for en SMS-tjeneste, hvilket begrænser problemet lidt (men ikke tilstrækkeligt, hvis der kan købes øl og vin på festivals o. lign.).

\subsubsection{Saldokontrol}

Lov om elektronisk kommunikation indeholder regler, der gælder for al elektronisk kommunikation. Lovens kapitel 5 vedrører tjenester til slutbrugere m.m., og efter regler i dette kapitel kan der pålægges en operatør at give adgang til mulighed for at en abonnent afgiftsfrit skal kunne spærre for visse typer af udgående samtaler eller numre, jf. kap. $5, \S 3$. Endvidere bestemmes det i kap. $5 \S 4$, at en operatør, der pålægges at udbyde en tjeneste med henvisning til kap. $5, \S 1$, kan pålægges vederlagsfrit at tilbyde saldokontrol og mulighed for forudbetaling. Disse regler gælder dog kun for fastnetabonnenter, og der er endnu ikke pålagt nogen operatør pligter efter kapitel 5.

\subsubsection{Opfylder svensk lovregulering forbrugernes behov for beskyttelse?}

Generelt kan det siges, at forbrugernes beskyttelse i forbindelse med mikroaftaler og mikrobetalinger efter svensk lovregulering har et relativt højt niveau, men at der er visse væsentlige huller i beskyttelsen.

Problemet vedrørende forbrugernes hæftelse for tredjemands misbrug af et betalingsmiddel kan blive alvorligt ved betalinger med overtakserede SMS/MMS'er. Dette er uafklaret i svensk ret, men bør afklares. En løsning kunne være, at anvende lov om forbrugerkreditaftaler $\S 34$ på dette forhold, men reglen bør suppleres med en selvrisikobegrænsning, således som det findes i Danmark og Norge. Mobiltelefonen som betalingsmiddel er ikke noget sikkert betalingsmiddel, da der ikke er tilknyttet en særlig kode til selve betalingsmidlet. Telefonens pinkode har kun som funktion at åbne telefonen for brug og betalingsfunktionen er herefter ubeskyttet. Dette forhold bør føre til, at forbrugernes hæftelse for uberettiget skal afvejes $i$ en balance mellem forbrugerens grad af uagtsomhed og teleudbydernes manglende udvikling af et sikkert betalingsmiddel.

Der er/vil blive et ganske væsentligt behov for dels at kunne udøve en effektiv saldokontrol, således at et vist maksimumbeløb ikke kan overstiges uden brug af en åbningseller påfyldningskode. Hjemlen for dette findes i svensk ret, men er endnu ikke udnyttet. Der ses endvidere et væsentligt behov for, at mobiltelefonabonnementer kan indrettes således, at der spærres for brugen af overtakserede SMS/MMS. Sådanne funktioner kunne være gavnlige for forældre, der ønsker at kunne overlade mobiltelefoner til deres mindreårige børn, ligesom visse erhvervsdrivende kunne være interesseret $\mathrm{i}$ dette. Som 
situationen er lige nu, må forældre eller andre, der ønsker en effektiv forbrugskontrol nøjes med de meget dyre taletidskort, hvilket ud fra et forbrugersynspunkt ikke er tilfredsstillende.

Fortolkningen af distanceaftaleloven $\S 10$, stk. 3, udgør yderligere et "hul" i forbrugerbeskyttelsen. Da udviklingen i mikrobetalinger går mod flere, større og dyrere enkeltstående køb kan man med denne fortolkning af fjernsalgsdirektivet artikel 5, stk. 2, have lavet ikke blot et lille hul i beskyttelsen af forbrugerne gennem sikring af de relevante og nødvendige oplysninger, men en hel vognport, hvorigennem væsentlige dele af forbrugernes beskyttelse ved fjernsalg forsvinder. Forudsætningen for, at den svenske fortolkning af direktivet ikke er i modstrid med direktivet er, at denne undtagelse fortolkes meget snævert. Dette hul i forbrugernes retsbeskyttelse lukkes ikke tilstrækkeligt ved ehandelslovens krav om ordrebekræftelse, men kan afbødes, ved at der stilles relevante krav til denne ordrebekræftelses indhold. Derudover kan forbrugerbeskyttelsen styrkes ved - ud over at anvende den snævre fortolkning af, hvilke aftaler, der er omfattet af undtagelsen - at indføre en beløbsgrænse for aftaler, hvor den erhvervsdrivende kan undlade opfyldelse af den efterfølgende oplysningspligt.

Indførelsen af en sådan beløbsgrænse eliminerer dog ikke problemet vedrørende fortolkningen af direktivet.

Særligt i forhold til børn og unge er der grund til at være opmærksom på udviklingen af mikrobetalingsmarkedet. Markedets struktur med små, spontane, modeprægede køb, med købemuligheden lige ved hånden og ofte knyttet til anvendelse af deres prestigefyldte "yndlingslegetøj nr. 1": Mobiltelefonen. Dette udgør på det nærmeste det ideelle marked for afsætning af ydelser til børn og unge. Beskyttelse af børn og unge mod indholdet i disse ydelser (sex og vold) kan reguleres af de eksisterende regler i markedsføringsloven. Beskyttelse mod at bruge en stor mængde penge er overladt til forældrene, som også er dem, der ifølge abonnementsaftalen med teleselskabet hæfter for børnenes forbrug. Det må derfor også sikres, at forældrene får adgang til de redskaber, der kan hjælpe med at styre og begrænse børn og unges forbrug. Dette kunne være adgang til saldokontrol, mulighed for at fravælge visse typer overtakserede SMS/MMS'er, særlig pinkode tilknyttet betalingsfunktionen, overgrænse for, hvad en SMS/MMS til børn må koste og hvor mange, der kan købes pr. abonnement pr. dag og/eller andet

Mobiltelefonens funktion som betalingsmiddel bør sikres, således at der ikke er fri adgang til forbrugerens konto, hvis en uberettiget tredjemand stjæler/finder en åben mobiltelefon. Beskyttelsen af forbrugerne bør sikres med indførelse af særlig pinkode, tilknyttet selv betalingsfunktionen og ikke som i dag, tilknyttet telefonen.

\subsubsection{Giver svensk lovregulering anledning til barrierer i udviklingen af mikro- betalingssystemer?}

Udviklingen i Sverige af mikrobetalingssystemer ligner udviklingen i Danmark og Norge. En stor del af de barrierer, der er for udviklingen af mikroaftalemarkedet, ligger på et andet plan end det juridiske. Den lovgivning, der findes på området er dog i nogen grad vanskelig at overskue og fortolke, hvorfor udfærdigelse af retningslinjer og vejledninger til de erhvervsdrivende muligvis kunne være til støtte for de erhvervsdrivende og dermed også til gavn for forbrugerne.

Oplysningspligten i lov om distanceaftaler udgør dog med det teknologiske stade, der findes i dag, men som er under stærk forandring, i nogen grad en praktisk vanskelighed, så længe mobiltelefoner endnu ikke er indrettet således, at de kan anses for at kunne 
modtage oplysninger på "læsbar og varig form". Løsningen på dette problem kunne som påpeget under afsnittene om Danmark og Norge være at acceptere henvisningen til en internetside som delvis opfyldelse af oplysningspligten for de forbrugere, der har egen internetadgang.

\subsection{Finland}

\subsubsection{Oversigt}

Den retlige regulering af mikroaftaler og mikrobetalingssystemer er også i Finland underlagt en lang række offentligretlige og privatretlige love. Dog har finsk ret det særpræg $\mathrm{i}$ forhold til Danmark, Norge og Sverige, at en stor del af de forbrugerbeskyttende love er samlet i et lovkompleks (konsumentskyddslagen), hvor de enkelte kapitler dækker områder, der i de andre lande er reguleret med en særlig lov. Den materielle retsstilling inden for det område, denne rapport dækker, er dog i vidt omfang parallelt og mange steder identisk med de øvrige nordiske landes (med undtagelse af Island, der på en del områder er reguleret på en lidt anden måde). For at undgå for mange gentagelser er der derfor ikke medtaget så fyldestgørende en beskrivelse af de områder, hvor der er en udstrakt grad af restsammenfald med reguleringen i de andre lande. Dette gælder særligt for markedsføringssystemet og den aftaleretlige regulering.

De offentligretlige regler, der har særlig betydning for mikroaftaler og mikrobetalinger, findes i konsumentskyddslagens kapitel 2 om regulering af markedsføringen og kapitel 3 om regulering af aftalevilkår, samt i lov om personoplysninger, lov om integritetsbeskyttelse ved telekommunikation og databeskyttelse uden for televirksomhed med tilhørende bekendtgørelse samt i lov om tillhandahållande av informationssamhällets tjänster (e-handels-loven) og i kommunikationsmarkedsføringsloven. E-handelsloven vil dog primært blive behandlet sammen med de privatretlige regler.

Der findes en lang række privatretlige regler, der også gælder for mikroaftaler og mikrobetalinger, men som ikke vil blive nærmere berørt på dette sted. Dette gælder bl.a. konsumentskyddslagen kapitel 5 om forbrugerkøb og kapitel 8 om visse konsumenttjenesteydelser, som kan tænkes at kunne komme på tale ved en mikroaftale (f.eks. køb af en vare eller vask af en bil). De privatretlige love, der har særlig relevans for denne rapport, er lov om retshandlinger på formuerettens område (aftaleloven), konsumentskyddslagen kapitel 3 om regulering af aftalevilkår og kapitel 4 om lempelse og fortolkning af aftaler, kapitel 6 om hjemmesalg og fjernsalg, kapitel 7 om forbrugerkredit, lov om formyndervirksomhed (myndighedsloven), og endelig lov om betalingsoverførsler.

\subsubsection{Offentligretlig regulering}

Den bærende lovgivning i finsk forbrugerbeskyttelse er konsumentskyddslagen, som er et lovkompleks, der regulerer en række områder, som er underlagt separate love i de øvrige nordiske lande. Konsumentskyddslagens kapitel 2 regulerer markedsføringen, og kapitel 2, $\S 1$, stk. 1, indeholder den generalklausul, der gælder for al markedsføring i relation til forbrugeren. Reglen bestemmer, at der ved markedsføring ikke må anvendes fremgangsmåder, der strider mod god skik eller som på anden måde er utilbørlig mod forbrugeren. Kapitel 2, $\S 1$, stk. 2, indeholder en generel pligt for de erhvervsdrivende til at give de oplysninger, som er nødvendige i forhold til forbrugernes sund- 
hed eller økonomiske sikkerhed. Denne regel gælder også for aktørerne på mikrohandelsområdet, og den forpligter på den måde, at markedsføring, der ikke indeholder de fornødne oplysninger, anses for utilbørlig og dermed kan forbydes eller pålægges restriktioner.

Kapitel 2, $\S 2$, rummer forbudet mod vildledning i finsk markedsføringsret. Reglen bestemmer, at der ved markedsføring ikke må gives usande eller vildledende oplysninger, og denne regel gælder også f.eks. prisoplysninger i mikroaftaler, ydelsernes kvalitet og egenskaber og oplysninger om en abonnementsaftales bindende virkning og eventuel opsigelighed.

Det er ikke tilladt at levere varer og tjenesteydelser til forbrugeren uden udtrykkelig bestilling, og det er dermed heller ikke tilladt at lade forbrugeren få indtryk af, at han er han er forpligtet til at betale for varen/ydelsen eller tilbagesende den, ophæve den, eller have nogen anden forpligtelse i den anledning, jf. konsumentskyddslagens kapitel 2, § 2 a. Denne regel må også gælde f.eks. for teleudbydernes udvidelse af abonnementsfaciliteter, såfremt et almindeligt mobiltelefonabonnement uanmodet udvides til at kunne anvendes (af abonnenten selv og af tredjemand) som betalingsmiddel.

Ud over disse generelle regler gælder der også i Finland en række specialregler i kapitel 2 , §§ 3-6, om tilgift, lotterier m.v. Disse gælder naturligvis også for mikrohandler, men vil ikke blive nærmere berørt her.

Konsumentskyddslagens kapitel 3 indeholder hjemmel for, at aftalevilkår, der anses for urimelige $\mathrm{i}$ forhold til forbrugerne af markedsdomstolen, kan forbydes den erhvervsdrivende at anvende som stridende mod god markedsføringsskik. Forbrugerombudsmanden, der overvåger forbrugerbeskyttelsen på dette område, jf. § 4.

Lov om personoplysninger gælder generelt til beskyttelse af privatlivet og den personlige integritet, jf. lovens $\S 1$. Loven gælder for automatisk behandling af personoplysninger og på anden behandling af sådanne oplysninger, som må anses at udgøre et personregister, jf. $\S 2$. Ved behandling af personoplysninger skal den registeransvarlige udvise agtpågivenhed og overholde god informationshåndtering, jf. $\S 5$. Lovens $\S 6$ opstiller nogle almindelige forudsætninger for behandling af personoplysninger, og de må kun behandles med den registreredes entydige samtykke ( $\S 8$, stk. 1, nr. 1) eller med en af de andre i $\S 8, n r .2-9$, opregnede begrundelser (nødvendigt for at beskytte den registreredes vitale interesser, for at kunne administrere eller inddrive en aftale vedrørende den registrerede m.v.).

Der gælder generelt et princip om et relevanskrav i registrering af personoplysninger. Der må således kun registreres i det omfang det er nødvendigt med hensyn til registreringens formål, jf. $\S 9$.

Som særlovgivning inden for telekommunikation gælder lov om integritetsbeskyttelse ved telekommunikation og databeskyttelse inden for televirksomhed med tilhørende bekendtgørelse (forordning). Denne lovs formål er at fremme databeskyttelsen inden for almindelig televirksomhed samt abonnenters og brugeres integritetsbeskyttelse og beskyttelse af berettigede interesser ved telekommunikation, jf. lovens $\S 1$. Loven gælder i almindelig televirksomhed og telekommunikation, som udøves gennem anvendelse af almindelige teletjenester samt ved fremstilling af abonnentkataloger. Loven gælder dermed både for mikrohandler foretaget over teleabonnement ved hjælp af overtakserede SMS/MMS'er og over Internettet via e-mail. Også andre mikrobetalingssystemer, der gør brug af telekommunikation, vil være omfattet af loven, jf. lovens $\S 2$. 
Teleselskabet er ansvarligt for databeskyttelsen inden for den televirksomhed, som det bedriver, jf. $\S 6$, og teleselskabet skal informere abonnenten om de særlige sikkerhedsrisici, som er forbundet med selskabets teletjenester samt om muligheden for at afhjælpe disse, jf. $\S 6$, stk. 2.

Teleselskabet må registrere oplysninger, som sætter det i stand til at udfærdige en teleregning på den enkelte abonnent, jf. $\S 10$, og teleselskabet skal efter bekendtgørelse til lovens $\S 1$ lagre sådanne oplysninger i mindst 3 måneder fra en teleregnings forfaldsdag, hvis teleforbindelsen faktureres løbende.

Hvis teleforbindelsen faktureres inden opkobling foretages (forudbetalt konto), skal teleselskabet ligeledes gemme de nødvendige oplysninger til identifikation af de enkelte poster på teleregningen i en 3 måneders periode, jf. $\S 1$.

Teleselskabet skal på abonnentens begæring udlevere en skriftlig, specificeret regning, jf. lov om integritetsbeskyttelse ved telekommunikation $\S 13$. Dette giver en abonnent mulighed for at kontrollere rigtigheden af teleregningen.

Kommunikationsmarkedsloven, som trådte i kraft i sin nuværende form i juli 2003, har til formål at fremme effektiviteten på telemarkedet i Finland med henblik på at fremme et passende udbud af tjenester, god konkurrence på markedet, højt niveau af teknisk udvikling og god kvalitet, driftssikre og trygge muligheder på markedet til rimelige priser, jf. lovens $\S 1$. Loven gælder i televirksomhed, jf. $\S 3$.

Efter denne lovs $\S 8$ er teleselskabet bl.a. pligtig til at sørge for faktureringen af teletjenester på behørig måde og at give sådanne oplysninger, som er nødvendige for faktureringen af forbruget på telenettet, jf. $\S 8$, stk. 2, nr. 6. Brugerne har krav på at få en specificeret regning pr. opkobling, jf. kommunikationsmarkedslovens $\S 15$, nr. 5.

Teleselskabet skal i medfør af kapitel $7 \S 79$ på brugerens begæring spærre for anvendelsen af andre tjenester end kommunikationstjenester og for udgående trafik for tilslutning til en bestemt trafiktype, hvis det er teknisk let at udføre denne spærring. Hvis spærringen senere ønskes ophævet, han teleselskabet opkræve et gebyr for dette.

Kommunikationsverket man meddele nærmere forskrift for, hvilke kategorier af udgående trafik fra en tilslutning, der som minimum skal tilbydes brugerne, samt om den tekniske udfærdigelse af spærringstjenesterne. Der er med hjemmel i denne bestemmelse udstedt föreskrift om spärrkategorier inom teletrafiken, der gælder såvel for fastnetforbindelser som for mobiltelefoni og kortmeddelelsestjenester (SMS/MMS).

Lov om tillhandahållande av informationssamhällets tjänster (e-handelsloven) er også en offentligretlig lov, men de regler, der findes om oplysningspligten, som har særlig interesse for denne rapport, vil blive gennemgået nedenfor sammen med de tilsvarende privatretlige.

\subsubsection{Privatretlig regulering}

\subsubsection{Indgåelse af aftale}

Det er også i Finland et grundlæggende princip aftaleretten, at vigtig information skal være tilgængelig umiddelbart i forbindelse med aftalens indgåelse. Den aftaleretlige konsekvens af, at dette ikke er tilfældet er, at de ikke oplyste vilkår ikke anses som en del af aftalen. De er således ikke vedtaget, og aftalen må udfyldes med almindelige formueretlige principper eller deklaratoriske lovregler. 
Indgåelse af aftale om tilslutning til et mikrobetalingssystem og af den enkelte mikroaftale er reguleret af lag om rättshandlinger på förmögenhetsrättens område (aftaleloven). Det system, der er opbygget i denne og i de andre nordiske landes aftalelove med tilbud og accept heraf gælder for alle typer aftaler - også for de meget små. Lovens regler om aftalers gyldighed i kapitel 3 gælder ligeledes disse aftaler, herunder generalklausulen i $\S 36$.

EU-direktivet om urimelige aftalevilkår i forbrugeraftaler er implementeret i konsumentskyddslagens kapitel 4.

Dette kapitels $\S 1$ indeholder den særlige formulering af generalklausulen, der gælder for forbrugerforhold i medfør af EU-direktivet.

Hvis et aftalevilkår har været udarbejdet i forvejen, uden at forbrugeren har kunnet påvirke dets indhold, og det var urimeligt under hensyn til de forhold, der blev rådet til ved aftalens indgåelse, kan senere ændringer i forholdene ikke komme forbrugerne til skade. Dvs. at hvor forholdene har udviklet sig til det (endnu mere) urimelige, kan denne udvikling tages med i vurderingen af aftalen, medens en gunstig udvikling, der måske gør, at aftalen nu ikke mere er så urimelig, ikke skal tages med i betragtning ved på forhånd udarbejdede urimelige aftaler,

Kontraktvilkår, der ikke er individuelt forhandlede mellem forbrugerne og den erhvervsdrivende, fortolkes indskrænkende, imod den erhvervsdrivende og til forbrugerens fordel, jf. $\S 3$. Dette er en videreførelse af et gammelt, fællesnordisk fortolkningsprincip for standardkontrakter, der også gælder ulovreguleret uden for forbrugerforhold.

Mindreårige under 18 år kan som udgangspunkt ikke selv indgå aftaler, der forpligter dem økonomisk, jf. lag om förmyndarverksamhet $\S \S 2$ og 23. Disse regler beskytter den mindreårige mod at påtage sig økonomiske forpligtelser, som han på grund af sin ungdom og mangel på erfaring ikke kan overskue. Det vil være i strid med god markedsføringsskik at forsøge at lade den mindreårige tro, at han er juridisk forpligtet, f.eks. ved køb over Internettet på kredit. Den mindreårige kan dog godt forudbetale med penge, han har til sin egen rådighed, og så bruge af kontoen senere. Dette vil kunne bruges ved forudbetalte systemer (taletidskort) med overtakserede SMS/MMS'er.

Som tidligere nævnt i denne rapport er beskyttelsen af mindreårige i nogen grad sat ud af spillet ved de overtakserede SMS/MMS'er i og med, at teleselskaberne stort set altid sørger for at have en myndig kontraktsansvarlig. Hermed "overvæltes" problemet om beskyttelse af mindreårige på børnenes/de unges forældre og værger. Dette understreger behovet for, at forbrugerne får mulighed for at udøve saldokontrol med de telefonabonnementer, der overlades børn og unge, og i høj grad behovet for at kunne få abonnementstyper, hvor betalingsmuligheden ikke findes eller kan fravælges.

\subsubsection{Oplysningspligten inden aftale indgås}

Oplysningspligten for den erhvervsdrivende ved markedsføring generelt og i forbindelse med den enkelte aftales indgåelse findes fastlagt i flere love også i Finland. Ehandelsloven supplerer og kompletterer konsumentskyddslagen og opstiller en række krav til afgivelse af oplysninger, der gælder generelt for handel ved hjælp af elektroniske kommunikationsmidler, lov om betalningsöverföringar må også omfatte betalingsformidlinger af mikrobetalinger foretaget f.eks. af teleselskaberne og andre, der formidler betalinger i mikrobetalingssystemer. Herud over gælder for mikroaftalerne reglerne om fjernsalg i konsumentskyddslagens kapitel 6 om hjemmesalg og distancesalg. Ende- 
lig findes i samme lovs kapitel 7 regler om forbrugerkredit, der gælder, hvis der til betalingssystemet er knyttet kredit omfattet af loven.

Lovens regler gælder dog ikke for den kredit, der fremkommer ved, at der betales samlet en gang om måneden eller pr. kvartal for det løbende forbrug, jf. lovens kapitel 7, § 1, stk. 2. Kreditaftaleloven vil derfor kun finde anvendelse, såfremt der til aftalen om tilslutning til betalingssystemet tilknyttes en egentlig kreditaftale gældende for de køb, der foretages, f.eks. ved overtakserede SMS/MMS-beskeder.

E-handelsloven (som ikke gælder for lotterivirksomhed, jf. § 4, stk. 1, nr. 5), opstiller i $\S 7$ almindeligt gældende krav om, hvilke oplysninger, tjenesteleverandøren skal holde tilgængelige for tjenestemodtageren og myndighederne. Disse oplysninger skal være tilgængelige ved markedsføring inden aftaleindgåelse, men det er ikke et krav, at oplysningerne alle er givet i enhver reklame eller annonce. $\S 7$ kræver blot, at oplysningerne er tilgængelige, hvilket vil sige, at en henvisning til en hjemmeside kan være tilstrækkelig.

De krævede oplysninger er: 1) tjenesteleverandørens navn, adresse, e-mailadresse samt anden kontaktinformation, der gør det muligt at nå leverandøren hurtigt, direkte og effektivt, 2) hvilken handelsregister m.v., som tjenesteleverandøren er indført i, 3) oplysning om eventuel tilsynsmyndighed, 4) merværdiskattenummer og eventuelt yderligere 1) eventuel brancheorganisation, 2) branchebetegnelse og 3) omtale af eventuelle regler, der regulerer virksomhedens virke i etableringsstaten.

Hvis prisen oplyses, skal denne angives klart og entydigt, og det skal fremgå, om prisen indbefatter skat og leveringsomkostninger, jf. § 7, stk. 2.

Inden en tjenestemodtager (her forbrugeren) afgiver bestilling, skal denne ud over ovennævnte information også i medfør af e-handelslovens $\S 8$ have oplysning om 1) de forskellige tekniske skridt ved indgåelse af aftalen, 2) hvorvidt aftalen gemmes af tjenesteleverandøren, og om dette sker på en måde, så den holdes tilgængeligt for den anden aftalepart, 3) de tekniske muligheder for at opdage og rette indtastningsfejl, inden bestilling afgives, 4) hvilke sprog aftalen kan indgås på og 5) de relevante adfærdskodekser, tjenesteyderen er tilsluttet, og hvorledes de kan findes elektronisk.

Disse oplysninger skal i medfør af $\S 8$, stk. 2, ikke gives, hvis aftalen indgås udelukkende gennem e-mail eller tilsvarende personlige henvendelser. Denne undtagelse gælder således ikke, hvor en forbruger reagerer på den erhvervsdrivendes reklamer, annoncer m.v. og heller ikke, hvor den erhvervsdrivendes e-mail reelt er en masseforsendelse; men med den enkelte modtagers navn og e-mailadresse.

Lov om betalingsoverførsler har i kapitel 3 regler om informationer om betalingsoverførsler.

En betalingsformidler skal give sine kunder letforståelig information om vilkårene for betalingsoverførsler, jf. $\S 4$. Informationen skal gives skriftligt og eventuelt også i elektronisk form (hvis f.eks. aftale om tilslutning til betalingsmidlet indgås elektronisk). Der skal gives information om, bl.a. hvor lang tid en betalingstransaktion må påregnes at tage, valueringsregler, gebyrer og omkostninger ved betalingstransaktioner, vekselkurser m.m.

Et stort flertal af mikrobetalinger vil være omfattet af reglerne om distanceaftaler i konsumentskyddslagens kapitel 6.

Dette gælder dog ikke aftaler, som indgås ved hjælp af vareautomat eller automatiseret forretningslokale, jf. kapitel $6, \S 6$, nr. 5, og heller ikke aftaler om brug af betalingstelefon (telefonboks) kapitel 6, $\S 6$, nr. 6 . 
Ikke alle mikroaftaler er distanceaftaler. Dette vil gælde, f.eks. hvor gæster på en festival til servitricen i en bod betaler for drikkevarer ved hjælp af overtakserede SMS/MMS'er.

Reglerne om distancesalg gælder dog ikke for salg af levnedsmidler og andre dagligvarer til forbrugere gennem fast distribueringssystem, jf. $\S 7$, stk.1, nr.1, og heller ikke aftaler om indkvartering, transport eller tjeneste, som angår serveringsvirksomhed eller fritidsaktiviteter, hvis den erhvervsdrivende ved indgåelse af aftalen binder sig til at udføre tjenesten på et bestemt tidspunkt eller møde for et vist tidsrum, jf. $\S 7$, stk.1, nr. 2.

Ved fjernsalg skal den erhvervsdrivende i god tid inden aftalen indgås, i medfør af lovens $\S 13$ give følgende information: Den erhvervsdrivendes navn og adresse, varens/tjenesteydelsens væsentligste egenskaber og prisen, leveringsomkostninger og betalingsvilkår samt øvrige vilkår for levering eller opfyldelse af aftalen. Herudover skal oplyses aftalens mindste løbetid ved aftale om løbende leverancer, omkostninger ved at anvende fjernkommunikation, hvis der beregnes en højere takst end normaltakst, den tid, som tilbudet gælder, og om der er fortrydelsesret i medfør af $\S 15$, eller at fortrydelsesret efter $\S 16$, stk. 1, nr. 2-7, ikke foreligger.

Der skal kort sagt - som i de øvrige nordiske lande - gives oplysninger om, hvem forbrugeren handler med, hvilken vare, der handles om, hvad kommer aftalen til at koste i alt, i hvor lang tid har forbrugeren dette tilbud, og kan forbrugeren eventuelt fortryde aftalen, efter at varen er bestilt.

Disse informationer skal i medfør af $\S 13$, stk. 2 gives på en måde, der er tilpasset det middel til fjernkommunikation, der anvendes. Oplysningerne skal være tydelige og forståelige og gives på en sådan måde, at det klart fremgår, at de gives med kommercielt formål. Ved kommunikation pr. telefon skal den erhvervsdrivende oplyse sit navn og samtalens kommercielle formål straks i begyndelsen af samtalen.

Der opstilles ikke i $\S 13 \mathrm{krav}$ til, hvilken form, de krævede oplysninger skal have ud over, at de skal gives i en form, der passer til det anvendte fjernkommunikationsmedium, og at de skal gives i god tid inden en eventuel aftale indgås, men e-handelslovens $\S$ 9 kræver, at aftalevilkår skal gøres tilgængelige for tjenestemodtageren på en måde, der gør det muligt for modtageren at gemme og gengive dem.

Tjenesteleverandøren skal endvidere stille enkle, effektive og lettilgængelige tekniske hjælpemidler til rådighed for modtageren, som gør det muligt at opdage og rette indtastningsfejl, inden bestilling afgives, jf. e-handelslovens $\S 10$, stk. 2.

De aftaler om tilslutning til et betalingsmiddel, hvori der også er en aftale om kredit, som er omfattet af konsumentskydsslagens kapitel 7, § 2, nr. 1, skal opfylde kravene i lovens kapitel 7 om bl.a., at den effektive rente skal angives, jf. kapitel 7, § 7, og at forbrugeren i medfør af kapitel $7, \S 9$, skal have information om de aftalevilkår og andre oplysninger, som fremgår af $\S 11$. Disse oplysninger angår kredittens beløb eller kreditramme, gebyrer, renter og andre omkostninger, betalings- og afdragsvilkår m.v.

Forbrugeren skal have disse oplysninger i skriftlig form, jf. kapitel 7, $\S 9$, men dette kan også være i elektronisk form, jf. e-handelslovens $\S 12$, der medfører, at elektronisk form skal kunne benyttes hvor lovgivningen kræver skriftlighed, forudsat at aftalens indhold ikke kan ændres ensidigt, og at aftalen findes tilgængelig for parterne.

\subsubsection{Oplysninger m.v. efter aftalens indgåelse}

Den erhvervsdrivende skal i medfør af e-handelslovens $\S 9$ gøre aftalevilkårene tilgængelige for tjenestemodtageren på en måde, der gør det muligt for modtageren at gemme 
og gengive dem, og når forbrugeren har afgivet bestilling med hjælp af elektroniske hjælpemidler, og der er indgået en aftale med den erhvervsdrivende, skal den erhvervsdrivende uden forsinkelse på elektronisk vis bekræfte modtagelsen af bestillingen jf. $\S$ 10, stk. 1 Der behøves dog ingen bekræftelse af bestillingen, hvis den bestilte ydelse leveres uden forsinkelse ad elektronisk vej, jf. $\S 10$, stk. 1, 2. pkt.

Ordrebekræftelse og fejlfindingsmidler skal ikke stilles til modtagerens rådighed ved aftaler, som indgås ved udveksling af e-mail eller anden tilsvarende personlig meddelelse. Det er som ovenfor nævnt en forudsætning, at udvekslingen af tilbud og accept er personlige og ikke pseudo upersonlige masseforsendelser, sådan som moderne kommunikationsteknik åbner mulighed for.

Ved fjernsalgsaftaler skal den information, der er omfattet af konsumentskyddslagens $\S$ 13, stk. 1 (den erhvervsdrivendes navn og adresse, ydelsens væsentligste egenskaber, pris, leveringsomkostninger, betalingsvilkår og andre vilkår for levering eller opfyldelse af aftalerne og aftalens eventuelle korteste løbetid) bekræftes over for forbrugeren skriftligt eller elektronisk på en måde, så oplysningerne ikke ensidigt kan ændres, og forbrugeren har varig adgang til den, jf. konsumentskyddslagens kapitel 6, § 14. Herudover skal forbrugeren have oplysning om, hvordan en eventuel fortrydelsesret kan udøves, henholdsvis at forbrugeren ikke kan træde tilbage, efter at udførelsen af en tjenesteydelse er påbegyndt, såfremt forbrugeren samtykker i påbegyndelsen inden fortrydelsesfristens udløb, jf. kapitel 6, $\S 16$. Der skal også oplyses om en fysisk adresse for eventuelle reklamationer, vilkår for garanti og service samt vilkår for opsigelse af aftalen.

Forbrugeren skal have bekræftelse så snart som muligt efter at aftalen er indgået og ved køb af vare senest ved leveringen, jf. kapitel 6, § 14, stk. 2.

Bekræftelse behøver ikke gives forbrugeren, hvis denne i overensstemmelse med $\S 14$, stk. 1, har fået den krævede information skriftligt eller på varigt medium, inden aftalen blev indgået. Bekræftelse behøver heller ikke tilstilles forbrugeren, hvis en tjeneste udføres på én gang ved hjælp af et fjernkommunikationsmiddel, og denne tjeneste faktureres af den næringsdrivende, som udbyder det fjernkommunikationsmiddel, som tjenesten udføres med, jf. $\S 14$, stk. 2. (Det skal dog erindres, at e-handelsloven $\S 10$ kræver, at den erhvervsdrivende uden unødigt ophold afgiver en elektronisk ordrebekræftelse, der dog ikke behøver være på varigt medium, og om hvis indhold intet er fastlagt).

Forbrugeren skal dog altid meddeles den fysiske adresse på den erhvervsdrivende, hvor forbrugeren kan henvende sig med reklamationer mod den erhvervsdrivende, som har udført tjenesten, jf. $\S 14$, stk. 3, sidste punktum.

Såfremt $\S 14$, stk. 3, forstås således, at den erhvervsdrivende ikke behøver give ordrebekræftelse på varigt medium ved enkeltstående leveringer af tjenesteydelser, således som det er tilfældet i Norge og Sverige, gælder de samme betænkeligheder, som nævnt ovenfor i afsnit 8.2.3.3., 8.2.4., (vedrørende Norge) og 8.3.3.3 og 8.3.4. (vedrørende Sverige) Da de forudgående oplysninger i medfør af $\S 13$ ikke kræves givet på papir eller $\mathrm{i}$ andet varigt medium, og der ikke gives ordrebekræftelse på varigt medium ved enkeltstående aftaler, kan forbrugeren få vanskeligt ved at dokumentere, at der er fejl i leverancen, og misforståelser/fejl i prisen eller andre aftalevilkår, og forbrugerens mulighed for at kontrollere sin kontoudskrift uger efter aftalen kan blive ganske vanskelig. Da "mikroaftaler" ikke nødvendigvis drejer sig om meget små beløb, men kan omhandle aftaler til 100-150 kr. eller mere, kan dette blive et alvorligt brud på forbrugerbeskyttelsen. 
De aftaler, der er omfattet af konsumentskyddslagens kapitel 7 om forbrugerkredit, skal opfylde kravene i kapitel 7, 111 , hvorefter en lang række oplysninger om kredittens beløb eller kreditrammen, gebyrer, renter, forfaldstid, afviklingsvilkår m.v. skal oplyses.

Forbrugerne skal have oplysning om renteændringer skriftligt i et kontoudtog eller på anden måde, jf. kapitel 7, $\S 11$, stk. 3. E-handelslovens $\S 2$ fastslår, at lovkrav om skriftlighed skal kunne opfyldes ved elektroniske aftaler og meddelelser, som ikke kan ændres ensidigt, og som er tilgængelige for parterne, hvorfor besked om renteændringer må kunne gives over e-mail til forbrugeren.

Lov om betalingsoverførsler kræver i $\S 5$, at kunden, når betaling er overført til modtageren, skal have mindst følgende information: 1) oplysninger, hvormed kunden kan identificere betalingsoverførslen, 2) det oprindelige beløb i betalingsoverførslen, 3) gebyrer og omkostninger, der debiteres kunden og 4) valueringsdag. Disse oplysninger skal gives kunden i letforståelig form skriftligt og efter behov i elektronisk form, hvis ikke kunden udtrykkeligt har afstået fra retten til at få disse oplysninger.

\subsubsection{Fortrydelsesretten}

Konsumentskyddslagens kapitel 6, $\S 15-18$, regulerer fortrydelsesretten ved fjernsalg. Fortrydelsesfristen er som udgangspunkt 14 dage, jf. $\S 15$, og denne frist regnes fra modtagelse af ordrebekræftelse ved tjenesteydelser, eller ved køb af vare, efter levering.

Se om problemerne med at fastlægge om en digital ydelse (f.eks. en bog eller en film) er en vare eller en tjenesteydelse, jf. ovenfor bl.a. afsnit 8.3.3.4.

Fortrydelsesretten gælder dog i medfør af $\S 16$ ikke 1) ved varer, som tilvirkes specielt til forbrugeren, 2) ved varer, som efter deres beskaffenhed ikke kan sælges igen, eller som hurtigt ødelægges eller forældes, 3) hvis forbrugeren har brudt forseglingen ved en lyd- eller billedoptagelse eller et dataprogram, der var forseglet ved leverancen, 4) ved tegning af abonnement på tidsskrifter og aviser, hvor det ikke er sælgeren, der på eget initiativ har kontaktet forbrugeren telefonisk og 5) ved spil og lotterier.

Fortrydelsesretten gælder heller ikke, hvis opfyldelsen af en tjenesteydelse eller en elektronisk leverance med forbrugerens samtykke er påbegyndt inden fortrydelsesfristens udløb, og forbrugeren gennem en bekræftelse som nævnt i $\S 14$ (ordrebekræftelse skriftlig eller på andet varigt medium) er blevet oplyst om, at fortrydelsesretten bortfalder, jf. $\S 16$, litra 1.

Hvis ordrebekræftelse efter $\S 14$ med oplysning om fortrydelsesretten ikke er givet, er aftalen ikke bindende for forbrugeren, jf. $\S 20$. Dette skal forbrugeren meddele den erhvervsdrivende inden 1 år efter aftalens indgåelse, jf. kapitel $6, \S 20$.

\subsubsection{Hæftelses- og ansvarsregler}

En teleudbyder skal i medfør af kommunikationsmarkedsføringslovens kapitel 7, § 76 uden forsinkelse spærre for tilslutning af eller forhindre anvendelse af en telefon, hvis brugeren oplyser, at en mobiltelefon, eller det SIM-kort (smartkort), der anvendes ved administrationen af mobiltelefonen er bortkommet, og anmoder om, at telefonen skal lukkes, eller at anvendelsen af telefonen skal forhindres.

Der findes ikke nogen bestemmelse om, hvorledes brugerens uagtsomhed skal bedømmes i situationer, hvor en uberettiget tredjemand har anvendt brugerens mobiltelefon. Ved forberedelsen af kommunikationsmarkedsføringsloven foreslog Konsumentverket, 
at der i loven skulle optages en regel svarende til bestemmelsen i konsumentskyddslagens kapitel 7, § 19.

Denne regel fastslår, at kontoindehaveren kun hæfter for uberettiget anvendelse af kreditkortet eller andet identifikationsmiddel som berettiger til adgang til kreditten hvis 1) han har overladt identifikationsmidlet til en anden, 2) det beror på en vis grad af uagtsomhed fra hans side at identifikationsmidlet er kommet i en uberettiget tredjemands besiddelse, 3) han på anden måde end som nævnt under nummer 2) har mistet besiddelsen af identifikationsmidlet og ikke uden opsættelse efter opdagelsen har anmeldt tabet hos kreditgiveren.

Kontoindehaveren hæfter dog ikke for uberettiget brug, der sker efter at meddelelse om bortkomsten er givet til kreditgiveren eller betalingsmodtageren ikke har udvist fornøden omhu og sikret sig, at den uberettigede tredjemand havde adkomst til brugen.

En sådan regel blev dog ikke indført i kommunikationsmarkedsføringsloven, hvorfor spørgsmålet om abonnentens hæftelse for tredjemands uberettigede brug en af mobiltelefon som betalingsmiddel også i Finland er uafklaret. En løsning på dette problem kan være at anvende ovennævnte $\S 19$ analogt på forholdet. Det kan ligeledes tænkes, at et aftalevilkår, hvorefter konsumentskyddslagens kapitel 7, § 19 ikke er anvendelig på hæftelsen for tredjemands uberettigede brug af telefonen som betalingsmiddel vil blive anset som stridende mod konsumentskyddslagens kapitel $3, \S 1$ om aftaler, der er urimelige $\mathrm{i}$ forhold til forbrugere.

\subsubsection{Saldokontrol}

Der findes i Finland ingen lovregler, der giver forbrugerne ret til at kræve mulighed for saldobegrænsning. Der findes kun regler om, at teleudbyderen kan bestemme en sådan begrænsning, ligesom teleudbyderen kan lukke for telefonen, hvis bestemte grænser overskrides. I praksis tilbydes brugerne dog mulighed for mod betaling at aftale saldokontrol og saldopåmindelse. Dette fungerer således, at forbrugeren selv bestemmer en overgrænse, som de månedlige udgifter til samtaler og SMS-meddelelser ikke må overstige. Hvis grænsen nås, kan brugeren ikke før næste periode begynder, foretage opkald eller sende flere SMS'er, hvis ikke saldogrænsen forhøjes. Ved saldopåmindelse får brugeren en påmindelse, når debiteringsbeløbet overstiger et bestemt, $\mathrm{i}$ forvejen aftalt beløb.

Der findes som ovenfor under punkt 8.4.2. i Finland mulighed for at lukke for visse ydelser i et telefonabonnement, således at telefonen ikke kan anvendes til overtakserede SMS/MMS-beskeder. Dette findes reguleret i kommunikationsmarkedsføringslovens kapitel 7, § 79 med tilhørende forskrift. Der skal kunne vælges spærring for forskellige kategorier af teletrafik, og dette gælder også for SMS/MMS'er. Der er opstillet en række kategorier i forskriften, og blandt disse er underholdningstjenester og voksenunderholdningstjenester. På brugerens begæring skal teleselskabet i medfør af forskriftens $\S 7$ koble muligheden for at sende SMS og MMS'er fra abonnementet.

\subsubsection{Opfylder finsk lovgivning forbrugernes behov for beskyttelse?}

Generelt kan det siges, at forbrugernes beskyttelse i forbindelse med mikroaftaler og mikrobetalinger også efter finsk lovregulering har et højt niveau, men at der er visse huller i beskyttelsen. Den finske kommunikationsmarkedsføringslov har dog løst et af de problemer, som findes i dansk, norsk, svensk og islandsk ret, idet man har fastlagt brugerens ret til spærring for visse typer teletrafik, herunder helt eller delvist for SMS/MMS'erne. 
Det ville være ønskeligt med en afklaring af forbrugernes retsstilling ved tredjemands uberettigede misbrug af mobiltelefonen som betalingsmiddel. Dette kan muligvis som nævnt løses ved en analog anvendelse af reglen i konsumentskyddslagens kapitel $7, \S$ 19, men indtil domstolene har taget stilling til dette spørgsmål, lever forbrugerne i et uhensigtsmæssig utryghed med risiko for, at dette kan udnyttes i urimelig grad.

Spørgsmålet om fortolkningen af fjernsalgsdirektivets artikel 5, stk. 2 vedrørende den erhvervsdrivendes pligt til at give forbrugeren ordrebekræftelse på papir eller andet varigt medium, således at dette ikke kræves ved enkeltstående leveringer er - som nævnt i afsnit 8.2.4. og 8.3.4 et alvorligt hul i forbrugerbeskyttelsen og næppe i overensstemmelse med direktivets regel. Se nærmere overvejelserne under disse afsnit.

Det bør muligvis også i Finland overvejes at indføre et selvstcendigt ansvar for teleselskaberne i forhold til forbrugerne, således at forbrugerne kunne kræve at teleselskaberne overfor dem og over for myndighederne skulle være ansvarlige for tjenesteudbydere, der i grov og/eller gentagen grad misligholder aftaler med forbrugerne, overtræder regler for god markedsføringsskik eller andre etiske regler eller på anden måde udviser adfærd, der er stærkt belastende for forbrugerne.

Særligt i forhold til børn og unge er der grund til at være opmærksom på udviklingen af mikrobetalingsmarkedet, der i høj grad appellerer til børns ønsker om små, sjove og spontane, modeprægede køb, med købemuligheden lige ved hånden og ofte knyttet til anvendelse af deres prestigefyldte "yndlingslegetøj nr. 1": Mobiltelefonen. Beskyttelse af børn og unge mod indholdet i disse ydelser (sex og vold) kan reguleres af de eksisterende regler i konsumentskyddslagen. Beskyttelse mod at bruge en stor mængde penge er overladt til forældrene, som også er dem, der ifølge abonnementsaftalen med teleselskabet hæfter for børnenes forbrug. Det er derfor positivt, at forældrene i Finland får adgang til de redskaber, der kan hjælpe med at styre og begrænse børn og unges forbrug i form af adgang til saldokontrol og mulighed for at fravælge visse typer overtakserede SMS/MMS'er. Herud over kunne tænkes tiltag med fastsættelse af en øvre grænse for, hvad SMS/MMS'er rettet mod børn maksimalt bør kunne koste.

Det kunne være ønskeligt, om brugen af telefonen som betalingsmiddel kun kunne ske efter åbning af denne funktion med en særlig kode. Dette ville sikre mod uberettiget tredjemands misbrug af en fundet eller stjålet mobiltelefon i dens funktion som bærer af et betalingsmiddel. Der bør derfor overvejes en sådan regel også i Finland.

\subsubsection{Giver finsk lovgivning anledning til barrierer i udviklingen af mikrobeta- lingssystemer}

Udviklingen af mikrobetalingssystemer i Finland ligner udviklingen i Danmark, Norge og Sverige. En stor del af de barrierer, der er for udviklingen af mikroaftalemarkedet, ligger på et andet plan end det juridiske. Den lovgivning, der findes på området er dog i nogen grad vanskelig at overskue og fortolke, hvorfor udfærdigelse af retningslinjer og vejledninger til de erhvervsdrivende muligvis kunne være til støtte for de erhvervsdrivende og dermed også til gavn for forbrugerne.

Oplysningspligten vedrørende distanceaftaler udgør dog med det teknologiske stade, der findes i dag, men som er under stærk forandring, i nogen grad en praktisk vanskelighed, så længe mobiltelefoner endnu ikke er indrettet således, at de kan anses for at kunne modtage oplysninger på "læsbar og varig form”. Løsningen på dette problem kunne som påpeget under afsnittene om Danmark, Norge og Sverige være at acceptere henvisnin- 
gen til en internetside som delvis opfyldelse af oplysningspligten for de forbrugere, der har egen internetadgang.

\subsection{Island}

\subsubsection{Oversigt}

Island har som de andre nordiske lande ikke nogen lovgivning, der specifikt regulerer mikroaftaler og mikrobetalinger, og retsstillingen må også her udledes af den lovgivning, der gælder på særlige områder.

Island har ikke en markedsføringslov, men markedsføringen er retligt reguleret af konkurrenceloven (samkeppnislögum). Derudover er der af anden lovgivning af relevans for mikroaftaler bl.a. lov om beskyttelse af persondata (lög um persónuvernd), lov om respekt af sikkerhed i betalingssystemer (lög um öryggi greiðslufyrirmæla i greiðslukerfum), lov om elektroniske signaturer (lög um rafrænar undirskiftir), lov om e-handel (lög um rafræn viðskipti og aðra rafræna pjónustu), lov om finansielle foretagender (lög um fjármálafyrirtæki) samt aftaleloven (lög um samningsgerð, umboð og ógilda löggerninga), myndighedsloven (lögræðislög) og kreditaftaleloven (lög um neytendalán). Der findes ingen særskilt lov om forbrugeraftaler, men dørslag og fjernsalg er reguleret ved lov om dørsalg og fjernsalg (lög um húsgöngu- og fjarsölu).

\subsubsection{Offentligretlig regulering}

Markedsføringen i Island er reguleret ved konkurrenceloven, hvis formål er at fremme effektiv konkurrence bl.a. ved at forhindre unødvendige begrænsninger i eller barrierer for friheden til at handle økonomisk, ved at forhindre unfair handelspraksis og begrænsninger i konkurrencen samt ved at understøtte nye markedsaktørers adgang til markedet.

Loven omfatter enhver form for kommerciel virksomhed inden for produktion af og handel med varer og tjenesteydelser.

Konkurrenceloven indeholder i artikel 20 generalklausulen vedrørende unfair handelsskik. § 20 lyder:

"Det er ikke tilladt at foretage sig noget, der strider mod god forretningsskik i erhvervsdrift, eller noget, der er utilbørligt mod forbrugernes interesser"

Artikel 21 indeholder et forbud mod vildledning, der indholdsmæssigt ligner de øvrige nordiske landes vildledningsforbud meget, og artikel 22 fastlægger dels, at reklame, rettet mod islandske forbrugere, skal være på islandsk, og indeholder der ud over en regel om oplysningspligt for den erhvervsdrivende.

Konkurrenceloven indeholder med disse regler i det væsentligste samme generelle regulering af markedsføringen, som de øvrige nordiske landes lovgivning. Disse regler gælder også i relation til mikrobetalingsmarkedet, og det kan således kræves, at markedsføringen af mikroydelser gives i overensstemmelse med god handelsskik, på en overskuelig og gennemsigtig måde og uden vildledning.

Tilsynet med overholdelse af konkurrenceloven varetages på handelsministerens vegne af Konkurrencerådet, jf. artikel 5.

Lov om e-handel implementerer e-handelsdirektivet. 
Serviceudbyderen skal i medfør af artikel 6 stille let og permanent adgang til en række informationer til rådighed. Disse informationer angår bl.a. den erhvervsdrivendes navn, adresse (post samt e-mail) samt diverse registreringsnumre. Artikel 6 følger nøje ehandelsdirektivets artikel 5 vedrørende den generelle oplysningspligt. Hvis prisen oplyses i sammenhæng med en vare eller tjenesteydelse, skal denne oplyses på en klar og utvetydig måde. Ved ydelser udelukkende rettet mod islandske forbrugere skal prisen være inklusiv moms, jf. artikel 6, stk. 3.

Direktivets krav om, at kontrakter skal kunne indgås elektronisk, hvis parterne ønsker dette, findes i lov om e-handel artikel 8. Loven kræver blot, at kontrakten er tilgængelig for begge parter og i en form, der kan opbevares (på et varigt medium), men ikke alle aftaler kan indgås elektronisk, jf. e.-handelslovens artikel 8, stk. 3.

Før indgåelse af elektroniske aftaler skal serviceyderen på en klar og utvetydig måde stille en række oplysninger til forbrugernes disposition, jf. lovens artikel 9, der nøje svarer til direktivets artikel 10. Inden ordreafgivelsen skal serviceyderen stille tilstrækkelige tekniske midler til identifikation og retning af fejl tilgængelige for forbrugeren. Heller ikke denne regel gælder dog for regler, der indgås udelukkende ved udveksling af email og på lignende individuel måde.

De oplysninger, der skal gives efter artikel 9, stk. 1, kan udelades ved aftaler, der udelukkende indgås ved brug af elektronisk mail el.lign. (f.eks. SMS). Dette forudsætter dog, som ovenfor nævnt under de tilsvarende afsnit for de øvrige lande, at der er tale om egentlig, individuel kommunikation, og ikke om massekommunikation "forklædt som" personlig post. En aftale, som er indgået på baggrund af reklamemateriale udsendt af den erhvervsdrivende, er heller ikke indgået udelukkende ved "individuel kommunikation".

Generelle kontraktsbetingelser skal dog være tilgængelige i en form, der tillader modtageren at gemme og reproducere dem, uanset at aftalen indgås via e-mail eller SMS/MMS.

Serviceyderen skal også i Island afgive elektronisk ordrebekræftelse, jf. artikel 10.

Lov om beskyttelse og behandling af personlige data implementerer EU-direktiv om behandling af personoplysninger og beskyttelse af privatlivets fred i den elektroniske kommunikationssektor, der ikke behandles nærmere i denne rapport. Loven kræver, at personlige data behandles på en fair, passende og lovlig måde, og at al behandling af persondata sker i overensstemmelse med god persondata/behandlingsskik, jf. artikel 7.

Loven opstiller herudover en række krav til, at oplysninger kun må indsamles til udtrykkelige passende formål og ikke må anvendes videre til anden formål bortset fra historiske, statistiske eller videnskabelige formål. De oplysninger, der må samles om personer, skal være adækvate, relevante og ikke gå yderligere, end formålet for indsamlingen.

Personlige data må kun behandles i det omfang et af de i artikel 8 nævnte kriterier er opfyldt. Dette er bl.a., at personen, som dataene vedrører, har givet utvetydigt samtykke til databehandlingen, at det er nødvendigt for opfyldelsen af kontrakts-forpligtelser, beskyttelse af legitime interesser m.v.

Også i lov om telekommunikation kapitel IX, findes regler om beskyttelse af personoplysninger og privatlivets fred. 
Den erhvervsdrivende må ikke uanmodet rette henvendelse til nogen ved brug af automatiske opkaldssystemer, fax eller e-mail jf. telekommunikationslovens artikel 46. Dog må den erhvervsdrivende markedsføre egne produkter via e-mail, hvis kunden i forbindelse med tidligere handel selv har givet sit telefon eller faxnummer eller e-mailadresse, og der findes en enkel og gebyrfri mulighed for at sige fra overfor yderligere markedsføring. Dette gælder for markedsføring generelt, og hvis markedsføringen er rettet mod forbrugere, gælder yderligere artikel 14 i lov om dørsalg og fjern-salg.

Lov om finansielle foretagender indeholder i kapitel 18 en regulering af elektroniske penge.

Artikel 79, stk. 2 kræver, at elektroniske penge skal kunne indløses i kontante penge til pålydende værdi uden andre udgifter, end hvad der er strengt nødvendigt til gennemførelse af ekspeditionen.

Kontrakt om indgåelse af aftale om elektroniske penge skal klart oplyse om betingelserne for indløsning af det elektroniske beløb, jf. artikel 79, men der kan fastsættes en undergrænse for, hvilket beløb, der kan udbetales i kontanter, men denne grænse må ikke sættes højere end 500 ISK.

E-handelsloven indeholder en række offentligretlige krav vedrørende oplysninger og ordrebekræftelse. Disse vil dog blive gennemgået i sammenhæng med de privatretlige regler.

\subsubsection{Privatretlig regulering}

\subsubsection{Indgåelse af aftale}

Ved indgåelse af aftalen om mikrobetalingssystemer gælder de generelle regler i aftaleloven. Artikel 36 indeholder en generalklausul om tilsidesættelse af urimelige aftaler, og denne regel er i 1995 udbygget med artikel 36 a-d, der implementerer EU-direktiv nr. 93/13 om urimelige aftalemidler. Der opstilles i henhold til direktivet særlige regler for forbrugeraftaler (artikel 36 a) bl.a. om fortolkning af aftaler, der ikke er blevet individuelt forhandlet mellem en forbruger og en erhvervsdrivende (artikel $36 \mathrm{~b}$ ), om muligheden for blot at ændre ét aftalevilkår samt en regel om, at der ved vurderingen af en aftales rimelighed ikke kan tages hensyn til efterfølgende omstændigheder til skade for forbrugeren.

For børn og unge under 18 år gælder det samme som i de øvrige nordiske lande, at de økonomisk er beskyttet af reglerne om inhabilitet til at handle økonomisk, jf. myndighedsloven. Mindreårige kan også i Island $\mathrm{i}$ et vist omfang disponere over selverhverv og gaver, men de kan ikke pådrage sig gældsforpligtelsen. Det gælder dog formentlig for Island som for de øvrige lande i denne undersøgelse, at betalingsmiddeludbyderen sikrer sig en myndig person som kontraktsansvarlig ved indgåelse af aftalen om tilslutning til betalingssystemer vedrørende mikrobetalinger.

\subsubsection{Oplysningspligten inden aftalen indgås}

Oplysningspligten vedrørende mikroaftaler reguleres i islandsk ret primært af lov om dørsalg og fjernsalg, men også kreditaftaleloven og e-handelsloven indeholder regler om oplysningspligten. 
Kreditaftaleloven gælder indgåelse af aftalen om tilslutning til et betalingsmiddelsystem, hvis der til denne aftale er knyttet en aftale om kredit. Aftalen skal udformes skriftligt, jf. artikel 5, og den skal indeholde en række oplysninger, jf. artikel 6 og 8 . Forbrugeren skal have en kopi af aftalen. Senest ved indgåelsen af aftalen skal forbrugeren have oplysning bl.a. om varens eller tjenesteyderens kontantpris, den årlige rente $\mathrm{i}$ $\%$, antallet af afdrag, de samlede omkostninger, som kreditten vil komme til at koste m.m.

Disse regler i kreditaftaleloven medfører, at selve tilslutningsaftalen ikke kan indgås pr. SMS/MMS, hvis den indebærer kreditmulighed, da aftalen skal indgås skriftligt med genpart til forbrugeren. Det er ikke i lovens ord udelukket, at aftalen kan indgås som "fjernlånsaftale", når blot forbrugeren får en genpart af aftalen indeholdende de i loven krævede oplysninger.(Ikke alle aftaler kan indgås elektronisk, jf. e-handelslovens artikel 8, stk. 3).

Lov om e-handel regulerer elektronisk handel og andre elektroniske serviceydelser, men ikke spil, som indebærer, at der gøres en indsats med penge $i$ hasardspil, herunder lotteri og væddemål. Hvor lovgivningen eller administrative regler eller andet kræver skrevne kontrakter (f.eks. så som kreditaftaleloven), må der ikke opstilles legale hindringer for, at kontrakten kan indgås ad elektronisk vej, forudsat at kontrakten er tilgængelig for begge parter på en måde, så begge parter i en form, der gendannes og opbevares, er let tilgængelig og vedvarende, jf. artikel 6 og 8 .

Kommerciel kommunikation i form af tilbud, konkurrencer og spil skal tilkendegive sig, så det tydeligt fremgår, at der er tale om en sådan kommerciel kommunikation, jf. artikel 7, stk. 2.

Udbyderen af elektroniske aftaler skal sørge for let og tilgængelig vedvarende adgang til de generelle informationer, der fremgår af artikel 6. Disse oplysninger om bl.a. navn, adresse (fysisk og e-mail), diverse offentlige registreringsnumre og eventuelle etiske kodeks, som serviceyderen er tilknyttet, kræves ikke givet på varigt medium.

Inden en ordre afgives, skal serviceyderen give adgang til oplysninger om, hvilke tekniske skridt, der skal tages for at indgå kontrakten, om kontrakten opbevares hos serviceudbyderen, og i så tilfælde, hvorledes det eventuelt vil være muligt at få adgang til den opbevarede kontrakt m.v. Herudover skal der også oplyses om muligheden for at finde og rette fejl ved indtastning af ordren.

De generelle kontraktbetingelser og salgsbetingelser skal stilles til rådighed for modtageren på en måde, så denne kan opbevare og gengive disse, jf. artikel 9.

Loven stiller ikke specificerede krav om, hvorledes oplysninger skal gives, og oplysninger givet på en internetside og ved e-mail kan opfylde lovens krav, men med kravene om muligheden for at opbevare og gendanne generelle oplysninger og kontraktbetingelser, vil SMS'er næppe opfylde lovens krav, således som teknikken i mange mobiltelefoner fungerer på nuværende tidspunkt.

Lov om dørsalg og fjernsalg gælder bl.a. ikke ved salg fra automater og ved aftaler om brug af offentlig telefon, jf. artikel 3, men vil i øvrigt gælde for en stor del af mikroaftalerne.

Sælger skal i medfør af lov om dørsalg og fjernsalg $i$ rimelig tid før en aftale indgås give oplysning om sit navn og adresse, det solgtes væsentligste egenskaber, betalings- 
og leveringsvilkår, fortrydelsesretten m.v. Ved telefonsalg skal sælger endvidere ved samtalens begyndelse oplyse sit navn og formålet med opringningen.

Loven opstiller ingen krav til, hvorledes disse oplysninger skal gives, blot at de skal gives, inden kontrakten indgås. Kravet om forudgående oplysninger gælder dog ikke ved aftaler om levnedsmidler og andre dagligvarer leveret til forbrugernes hjem eller arbejdsplads, ved salg af indkvartering, transport, forplejning og lign., når det er aftalt, at ydelsen skal leveres på et bestemt tidspunkt eller i en bestemt periode, og dette klart fremgår af kontrakten. Oplysningspligten gælder endvidere ikke ved salg af fritidsaktiviteter, så som billetter til sport og kulturelle begivenheder og lign., når det fremgår af aftalen, hvilken dag eller inden for hvilken bestemt periode, den pågældende tjenesteydelse skal udføres.

\subsubsection{Oplysningspligten efter aftaleindgåelsen}

Når aftalen, der indebærer mikrobetalingen, er indgået, har forbrugeren krav på ordrebekræftelse leveret af serviceyderen straks efter modtagelsen af ordren. Ordrebekræftelsen skal ske i elektronisk form, jf. lov om e-handel artikel 10.

Lov om dørsalg og fjernsalg artikel 6 kræver, at der skal gives en ordrebekræftelse på papir eller på andet varigt medium, som forbrugeren har adgang til og rådighed over, og at denne ordrebekræftelse indeholder de oplysninger, som findes i artikel 5, stk. 1, litra 1-6. Dvs. oplysning om sælgerens navn og adresse, det solgtes væsentligste egenskaber, prisen på ydelsen, prisen for at anvende fjernkommunikation, betalings- og leveringsbetingelser samt fortrydelsesretten.

Forbrugeren har krav på disse oplysninger inden for rimelig tid inden kontraktens opfyldelse og senest ved leveringen af varen. Ved serviceydelser skal ordrebekræftelsen med de deri indeholdte oplysninger gives på det tidspunkt, hvor aftalen udfærdiges og aldrig senere end på den 6. dag efter aftalens indgåelse. Forbrugeren har altid krav på skriftlige oplysninger om fortrydelsesretten samt oplysning om sælgers adresse og nationalitet, mulighed for at klage over det købte, oplysning om garanti og service og opsigelsesvilkår ved løbende aftaler uden sluttidspunkt, eller som løber mere end 1 år, jf. artikel 6, stk. 2 .

Artikel 6, stk. 3, indeholder undtagelsen om, at de oplysninger, der kræves i medfør af artikel 6, stk. 2, ikke skal gives ved salg af fjernkommunikationsserviceydelser (teletjenester), hvor serviceydelsen bestilles og leveres på én gang, og vederlaget for ydelsen opkræves af udbyderen. Forbrugeren skal dog under alle omstændigheder have oplysninger om leverandørens adresse, jf. stk. 2, nr. 2. Som eksempel nævner loven herefter telefonoplysninger. Undtagelsen i fjernsalgsdirektivets artikel 5, stk. 2, fortolkes således på linje med den måde, det hidtil har været fortolket i Danmark, og som er i overensstemmelse med direktivets formål med undtagelsen og med bemærkningerne til direktivet.

Der gælder i Island ikke nogen undtagelse fra kravet om de oplysninger, der skal gives efter aftalens indgåelse svarende til undtagelsen for forudgående oplysninger for visse ydelser (levnedsmidler, transport, sports-, biograf- og teaterbilletter m.m.).

Hvis sælger/serviceydelsesleverandøren ikke giver de oplysninger, der kræves i medfør af artikel 6 inden for lovens tidsramme (dvs. ved serviceydelser senest 6 . dagen efter aftalens indgåelse), er kontrakten ikke bindende for forbrugeren, jf. artikel 6, stk. 5. 


\subsubsection{Fortrydelsesret}

Forbrugeren har ret til at fortryde en aftale omfattet af lov om dørsalg og fjernsalg i 14 dage efter levering af en vare, solgt ved dørsalg eller fjernsalg og ved serviceydelser 14 dage fra aftalens indgåelse, men dog aldrig mere end 6 dage efter kontraktens udfærdigelse, hvis sælgeren har opfyldt sin forpligtelse til at give oplysninger i medfør af artikel 6 , jf. artikel 9.

Forbrugeren kan ikke benytte fortrydelsesretten, hvis han har samtykket i levering af en serviceydelse inden fristens udløb, jf. artikel 10, litra 1. Fortrydelsesretten ophører ligeledes ved køb af videobånd, lydoptagelser og software, når forbrugeren bryder sælgerens forsegling heraf (litra 2). Det samme gælder for varer, der fremstilles efter forbrugernes særlige specifikationer eller på anden måde efter forbrugernes særlige behov, eller som ifølge deres natur vil forringes eller udløber inden fristens udløb (litra 3). Der er endelig ingen fortrydelsesret ved fjernsalgsaftaler om deltagelse i lotterier eller andet lovligt spil, jf. artikel 10, litra 4.

Undtagelserne til fortrydelsesretten i artikel 10, litra 1-4, kan omfatte en del af de mikroaftaler, der er denne redegørelses emne.

Artikel 10, litra 1, vedrørende tjenesteydelser, hvor fortrydelsesretten ophører ved forbrugernes samtykke, forudsætter dog, at forbrugeren inden leveringen er underrettet om, at der er en fortrydelsesret, og at forbrugeren ved en bestemt handling giver afkald herpå, da også den islandske lov om dørsalg og fjernsalg er præceptiv, således at forbrugeren ikke på en aftales indgåelse kan give afkald på de rettigheder, loven giver, jf. artikel 1, stk. 2.

Alternativt til, at forbrugeren, efter at aftalen er indgået, giver afkald på fortrydelsesretten, kan leverandøren af lyd- og billedoptagelser samt software sikre sig, at forbrugeren først kan få adgang til disse ydelser ved at bryde en kode. Dette kunne omfatte ringetoner, vitser, horoskoper m.v. Det forudsættes dog stadig, at forbrugeren er blevet oplyst om sin fortrydelsesret, inden den elektroniske forsegling/koden brydes, og konsekvenserne heraf.

\subsubsection{Hæftelses- og ansvarsregler}

Lov om dørsalg og fjernsalg indeholder ikke nogen regel om hæftelse for tredjemands svigagtige misbrug. Artikel 12 bestemmer blot, at erhvervsdrivende, der udsteder betalingskort, skal fastsætte klare regler for, hvornår en forbruger kan kræve annullering af en betaling, hvis hans betalingskort er blevet brugt svigagtigt til indgåelse af en fjernsalgsaftale omfattet af loven om dørsalg og fjernsalg. Udstederen skal endvidere opstille betingelser for de tilfælde, hvor forbrugeren kan få tilbageført penge i tilfælde af tredjemands misbrug af betalingskortet.

\subsubsection{Saldokontrol}

Lov om telekommunikation trådte i kraft den 25. juli 2003. Dennes artikel 50 bestemmer, at erhvervsdrivende uden krav om gebyr på kundens begæring skal spærre for bestemte typer af telefonsamtaler eller for samtaler i bestemte numre.

Der findes ingen lovregler, der giver forbrugerne krav på kunne udøve saldokontrol med et telefonabonnement, og de islandske forbrugere, der ønsker forbrugskontrol er hermed henvist til de dyre taletidskort. Et stort teleselskab tilbyder den mulighed, at spærre for SMS/MMS'er, der overskrider $14 \mathrm{ikr}$. 


\subsubsection{Opfylder islandsk lovregulering forbrugerens behov for beskyttelse?}

Den islandske konkurrencelov giver ikke en tilsvarende fleksibilitet og beskyttelse af forbrugernes interesser, som de øvrige nordiske landes markedsføringslovgivning med dertil hørende forbrugerombudsmandsinstitutioner. Konkurrenceloven indeholder dog et generelt regelsæt til beskyttelse mod unfair forretningsskik og vildledende adfærd og med krav om oplysninger i forbrugerforhold. Forbrugerbeskyttelsen mangler detailregler vedrørende teleudbydernes forpligtelser $\mathrm{i}$ forhold til at give mulighed for kontrol med, at registrering af forbruget er korrekt samt mulighed for at sætte en overgrænse over forbruget (saldokontrol) og begrænsninger i adgangen til bestemte services (spærring). Der mangler endvidere i høj grad bestemmelser vedrørende sikkerheden i betalingssystemer og hæftelse i forbindelse med tredjemands uberettigede brug af et betalingsmiddel, ligesom der mangler en sikkerhed for forbrugeren ved systemfejl og systemnedbrud.

\subsubsection{Giver islandsk lovregulering anledning til barrierer i udviklingen af mikrobetalingssystemer}

De færre lovregler, der findes i islandsk lovgivning i forhold til de øvrige nordiske landes lovgivning, kan ses som en lettelse af erhvervslivets muligheder for at udvikle mikrobetalingssystemer, men dette er ikke udelukkende en fordel: Det må forventes, at Kommissionen inden for en nærmere fremtid vil gribe ind, såfremt markedet ikke udvikler sig afbalanceret med en rimelig grad af forbrugerbeskyttelse. Ligeledes må det forventes, at de islandske domstole vil gribe ind, såfremt de erhvervsdrivende ikke varetager forbrugernes interesser på et niveau, der svarer nogenlunde til det, der er kommet til udtryk i Kommissionens henstilling om transaktioner ved elektroniske betalingsmidler. Hvis de erhvervsdrivende selv skal finde og fastlægge disse rammer for forbrugerbeskyttelsen, kræver det, at de relevante parter sammen udvikler frivillige kodeks. I modsat fald kan den manglende regulering føre til konkurrenceforvridende forhold, idet de etisk ansvarlige og "pæne" erhvervsdrivende vil pålægge sig selv begrænsninger i forhold til forbrugerne, hvilket de "mindre pæne" kan undlade. Et afbalanceret og forholdsvist detaljeret regelsæt kan derfor på langt sigt vise sig at være en fordel for de erhvervsdrivende som helhed. 


\section{BELGIEN \& LUXEMBOURG}

Jean de Lannoy

Avenue du Roi, 202, 1190 Brussels

Tel +32 (0)2 5385169

Fax +32 (0)2 5380841

jean.de.lannoy@euronet.be

\section{CANADA}

Renouf Publishing Company Ltd

5369 Canotek Road, Ottawa,

Ontario K1J 9J3

$\mathrm{Tel}+1$ (613) 7452665

Fax + 1 (613) 7457660

order.dept@renoufbooks.com

www.renoufbooks.com

\section{DANMARK}

Svensk-Norsk Bogimport A/S

Esplanaden 8 B, 1263 København K $\mathrm{Tel}+4533142666 \mathrm{Fax}+4533143588$ snb@bog.dk

www.snbog.dk

\section{ESTLAND}

Astro Raamatud AS

Pärnu mnt 142, 11317 Tallinn

Tel +372 6548485 Fax +372 6548475

book@astro.ee

\section{FINLAND}

Akademiska Bokhandeln

PB 128, Centralgatan 1,

00101 Helsingfors

Tel +358 912141

akatilaus@akateeminen.com

www.akateeminen.com

\section{FRANKRIG}

Librairie LAVOISIER

14, rue de Provigny,

94236 Cachan Cedex

Tel +33 (1) 47406700

Fax +33 (1) 47406702

group@lavoisier.fr

www.lavoisier.fr

\section{F/ERøERNE}

H.N. Jacobsens Bókahandil

Postboks 55, 110 Tórshavn

Tel +29831 1036 Fax +298317873

hnj@hnj.fo

www.hnj.fo

\section{HOLLAND}

De Lindeboom Internationale Publicaties

M.A. de Ruyterstraat 20 A,

NL-7482 BZ Haaksbergen

Tel +31 (0)535740004

Fax +31 (0)53 5729296

books@delindeboom.com

www.delindeboom.com

\section{ISLAND}

Mál og Menning

Laugavegi 18, 101 Reykjavik

Tel +354 (9)5152500

Fax +354 (9)515 2505

books@penninn.is

\section{KINA}

CNPIEC

Europe Division 16 Gongti East Road

P.O. Box 88, Beijing

Tel +86 $105066688-8$

Fax +86105063101

\section{LETLAND}

Jana Rozes Gramàtnica

Kr. Barona iela 5, 1011 Riga

$\mathrm{Tel}+371$ (0)2 284288

Fax +3717370922

\section{LITAUEN}

Penki Kontinentai

A. Stulginskio 5, 2001 Vilnius

Tel +370 (5) 2664540

Fax +370 (5) 2664565

books@5ci.lt

www.books.lt

\section{NORGE}

Akademika A/S

Postboks 84 Blindern, 0314 Oslo

Tel +4722 $853030 \mathrm{Fax}+4722853080$

bloken@sio.uio.no

www.akademika.no

\section{RUMAENIEN}

Euromedia s.r.l.

Str Dionisie Lupu nr 65, 70184 Bucuresti

$\mathrm{Tel}+4016140664$

Fax +4013129646

\section{STORBRITANNIEN}

The Stationery Office

P.O. Box 276, London SW8 5DT

Tel +448706005522

Fax +448706005533

customer.services@tso.co.uk

www.tso.co.uk/bookshop

\section{SVERIGE}

Fritzes

Kundservice, 10647 Stockholm

Tel +46 (0)8 6909190

Fax +46 (0)8 6909191

order.fritzes@nj.se

www.fritzes.se

\section{TYSKLAND}

UNO-Verlag GmbH

Am Hofgarten 10, 53113 Bonn

Tel +49 (0)228949020

Fax +49 (0)228 9490222

info@uno-verlag.de

www.uno-verlag.de

\section{UNGARN}

Euro Info Service

PO Box 1039, 1245 Budapest

Tel +36 (1) 3292487

Fax +36 (1) 3492053

euroinfo@euroinfo.hu

USA

Bernan

4611-F Assembly Drive,

Lanham MD 20706-4391

Tel +1 (301) 4597666

$\mathrm{Fax}+1$ (301) 4590056

query@bernan.com

www.bernan.com

\section{ÅLAND}

Lisco bok- och pappershandel Skarpansvägen 25, Box 8 , 22101 Mariehamn Tel +358 (0)1817177 Fax +358 (0)18 19771 info@lisco.fi 